Roberto Cesar Scacchetti de Castro

\title{
Legitimidade Ativa no Mandado de Segurança Coletivo
}

Dissertação apresentada ao Departamento de Direito Processual da Faculdade de Direito da Universidade de São Paulo como requisito parcial para obtenção do título de Mestre em Direito, sob orientação do Professor Rodolfo de Camargo Mancuso

Faculdade de Direito da Universidade de São Paulo Departamento de Direito Processual São Paulo 
Legitimidade Ativa no Mandado de Segurança Coletivo 
Banca Examinadora 
"Pensar e agir coletivamente é, antes de mais nada, conduzir-se inteligentemente, porque a reunião dos esforços individuais é o instrumento mais eficaz para a consecução do fim comum"

Rodolfo de Camargo Mancuso 
2. Leitura Contemporânea das Condições da Ação

2.1. A Possibilidade Jurídica do Pedido

2.2. Interesse Processual $\quad \mathbf{2 3}$

2.3. Legitimidade $\quad \mathbf{2 8}$

3. A Representação Adequada $\quad 40$

3.1. Procedimento da Ação Coletiva nos Estados Unidos 4

3.2. Representação Adequada no Brasil $4 \mathbf{4 3}$

4. Pertinência Temática 46

5. A Legitimação no Mandado de Segurança Individual 50

5.1. Evolução Histórica do Instituto

5.2. Natureza Jurídica

5.3. Requisitos

6. A Tutela dos Interesses Coletivos

6.1. Evolução Histórica do Instituto

6.2. Os Direitos Difusos, Coletivos e Individuais Homogêneos 58

6.3. A Tutela de Direitos Difusos em Sede do Mandado de Segurança Coletivo $\mathbf{6 5}$

7. A Legitimação para Proteção dos Interesses Coletivos 72

8. A Legitimação Ativa para Tutela Coletiva em Outros Países 76

9. A Legitimação Ativa no Mandado de Segurança Coletivo no Brasil 77

10. O Tema da Legitimidade no Projeto de Código de Processos Coletivos 82

11. O Tema da Tutela Coletiva no Projeto de Código de Processo Civil 85

12. O Rol de Legitimados $\quad 88$

12.1. Organização Sindical, Entidades de Classe e Associação $\mathbf{8 8}$

12.2. Partidos Políticos $\quad 96$ 
13.1. Ministério Público $\quad \mathbf{1 0 3}$

13.2. Defensoria Pública

14. A Atividade dos Legitimados 116

14.1. O Caso da Tarifa de Assinatura Telefônica Residencial 116

14.2. Expurgos Inflacionários das Cadernetas de Poupança 119

15. Considerações Conclusivas 121

$\begin{array}{lr}\text { 16. Bibliografia } & 123\end{array}$

18. Resumo 139

18. Riassunto 140 


\section{Introdução}

É intrínseco ao ser humano o convívio social como forma de propiciar o atendimento aos seus anseios basilares. Notório que o homem não consegue viver dignamente sem "conviver" e, se, por um lado, existe uma tendência incoercível dos homens para a vida social, por outro, se tem verificado, no curso da história, que são inevitáveis os conflitos de interesses entre eles ${ }^{1}$.

Incumbe ao direito, nesse contexto, regular e ordenar as relações humanas, de forma a propiciar a adequada composição entre os diversos interesses que se manifestam na sociedade. $\mathrm{O}$ objetivo do direito é harmonizar as relações sociais da melhor forma possível, evitando-se a propagação dos conflitos.

Embora possua essa função específica, o direito não é capaz de por fim a todos os conflitos que surgem. Tal fato gera grande insatisfação social que necessita ser debelada de alguma forma, seja pela intervenção do Estado, seja através da autocomposição entre as partes envolvidas.

O Estado, hoje, é capaz de dirimir os conflitos que envolvem as pessoas, decidindo sobre as pretensões apresentadas e impondo as decisões. Esta faceta do poder estatal é designada jurisdição, tecnicamente conceituada como o instrumento por meio do qual os órgãos jurisdicionais atuam para pacificar as pessoas conflitantes, eliminando os conflitos e fazendo cumprir o preceito jurídico pertinente a cada caso que lhes é apresentado em busca de solução ${ }^{2}$. Nesse sentido, embora a doutrina pátria arrole inúmeros escopos desta faceta do poder estatal (políticos e sociais - educação, respeito ao próximo, preservação do ordenamento jurídico e atuação da vontade concreta do direito), o escopo magno da jurisdição é o da pacificação social ou pacificação com justiça.

A atribuição da resolução dos conflitos existentes entre os cidadãos dá-se hoje fundamentalmente por meio do Estado.

\footnotetext{
${ }^{1}$ Arruda Alvim, José Manoel de. Código de Processo Civil Comentado. São Paulo: Editora Revista dos Tribunais, vol. 1.

${ }^{2}$ Cintra, Antonio Carlos de Araújo; Dinamarco, Cândido Rangel; Grinover, Ada Pellegrini. Teoria Geral do Processo. São Paulo: Editora Malheiros, 2007.
} 
Ocorre que, a morosidade do provimento jurisdicional, em vista da sobrecarga do Poder Judiciário, apresenta-se como grave problema do sistema brasileiro. Tal fato gera enorme descrédito da função estatal no tocante à solução dos conflitos sociais.

O problema não se refere somente à morosidade de nossas instituições judiciais e jurídicas, mas também a uma cultura de litigância e do mau uso que acaba se fazendo dos instrumentos processuais de maneira a protelar decisões definitivas, tornando o processo excessivamente demorado e custoso.

Uma das alternativas a tal situação é a resolução em demanda única (coletiva) do interesse de diversos indivíduos, evitando (mas não obstando), que haja a distribuição de grande quantidade de demandas sobre a mesma temática por cada particular afetado.

Nesse passo, a demanda coletiva visa a dar efetividade ao provimento jurisdicional que seria buscado pelo indivíduo de per si. A ação coletiva tem por objetivo precípuo, ainda, proporcionar o acesso dos hipossuficientes ao judiciário, através da defesa de seus interesses em situações específicas definidas pela lei, evitando que estes necessitem ingressar com demandas individuais nesse sentido.

Notoriamente que, como se verá, a tutela coletiva possui reflexos não apenas na jurisdição (e provimento jurisdicional), mas também na ação e no processo, como forma de atendimento à instrumentalidade deste.

É nesse contexto que se insere o tema escolhido para o presente trabalho, bem como a razão de sua escolha. Pretende-se abordar uma visão atual dos legitimados à tutela do mandado de segurança coletivo no direito processual brasileiro, bem como as discussões relativas ao âmbito de atuação destes e direitos a serem preservados.

O presente trabalho busca demonstrar a relevância do tema, bem como apontar os principais pontos de discussão sobre o rol de legitimados ativos para impetrar o mandado de segurança coletivo e suas possibilidades de atuação, quer no âmbito legal e doutrinário, quer no âmbito jurisprudencial, trazendo conclusões acerca do quanto discutido. 
Primeiramente, são abordadas as questões relativas às condições da ação sob um enfoque contemporâneo, trazendo as principais alterações doutrinárias na exegese dos requisitos necessários para o desenvolvimento válido do processo e seu julgamento com resolução de mérito. No presente trabalho, não são abordados detidamente os pressupostos objetivos e subjetivos que permitem a regular constituição do processo, compondo judicialmente a lide com uma relação processual perfeita, mas tão somente os requisitos que necessitam ser cumpridos para o prosseguimento da lide com resolução de seu mérito.

Nesse sentido, foram analisados (i) a possibilidade jurídica do pedido, (ii) o interesse processual e (iii) a legitimidade das partes, com enfoque principal na legitimação ativa das demandas. Nada obstante, são mencionados também alguns pontos relevantes sobre o tema das condições da ação, como ocorre no caso da interpretação das condições da ação como questões de mérito. Nesse sentido, há referência ao fato do projeto de Código de Processo Civil excluir a possibilidade jurídica do rol de condições da ação.

Após, a legitimação ativa individual é abordada em confronto com a coletiva, contrapondo o tratamento molecular de direitos em relação aos conflitos de forma fragmentada, em que o direito de ação figura como verdadeiro direito de propriedade.

Nesse ponto, são analisadas as teorias que embasam a legitimação coletiva, bem como as mudanças já efetivadas na legislação processual, que tratam da tutela dos direitos transindividuais e especificamente do mandado de segurança coletivo. Há menção, ainda, às class actions (do direito norte-americano), sem qualquer intenção de esgotar ou aprofundar-se sobre o tema, mas apenas como referência à origem da tutela coletiva de direitos e fonte do direito pátrio.

A análise fundamental ocorrerá, ainda, quanto ao art. 5, LXX, da $\mathrm{CF} / 88$, bem como em relação ao Código de Defesa do Consumidor, à Lei 1.533/51 e a recente Lei 12.016/09, que regulamentam especificamente o instituto, por conta da natureza mista de mandado de segurança e demanda coletiva. 
Em uma segunda etapa são referidas as principais questões acerca do mandado de segurança coletivo e os seus problemas, sendo a legitimidade para sua impetração um dos principais deles. São aduzidos pontos específicos quanto à legitimação em sede de mandado de segurança coletivo, trazendo as questões doutrinárias e jurisprudenciais de maior relevância.

No estudo que se desenvolveu, pretendeu-se abordar os seguintes aspectos relacionados ao tema: (i) principais problemas quanto à legitimação ativa no mandado de segurança coletivo, (ii) o rol de legitimados, (iii) possíveis legitimados e âmbito de atuação, conforme casos práticos relevantes.

Objetivou-se, a partir de situações práticas, traçar os núcleos de maior discussão sobre a legitimidade ativa, bem como quanto aos direitos e sujeitos objeto da tutela.

A partir de tal análise foram formuladas considerações conclusivas, trazendo-se proposições e interpretações sobre possíveis legitimados e situações a serem protegidas pelo mandado de segurança coletivo, além daquelas expressamente previstas na legislação sobre o tema, que é o escopo fundamental do trabalho.

\section{Leitura contemporânea das condições da ação no que concerne à legitimidade ativa na ação individual e coletiva}

O direito de agir, embora autônomo e abstrato, está conexo, instrumentalmente, a uma pretensão, pelo que se liga a uma situação jurídica concreta sobre a qual deve incidir a prestação jurisdicional invocada. Por esse motivo, o jus actionis se subordina a condições que se relacionam com a pretensão a ser julgada. Chamam-se condições da ação os elementos e requisitos necessários para que o juiz decida o mérito da pretensão, aplicando o direito objetivo a uma situação contenciosa. Nesse sentido, Liebman defendeu "a autonomia da ação em face do direito subjetivo material e nela identificou o direito subjetivo processual". 3

\footnotetext{
${ }^{3}$ LIEBMAN, Enrico Tullio. Manuale di diritto processuale civile. 3. ed. Milão: Giuffrè, 1973. n. 73, vol. I, p. 117.
} 
Importante para o estudo específico das condições da ação se mostra a análise das teorias sobre a natureza jurídica da ação, que antecederam o reconhecimento da autonomia do direito de ação.

A primeira delas refere-se à teoria civilista, clássica, imanentista ou privativista, que foi adotada por Savigny. Referido autor desenvolveu a teoria em questão (oriunda do direito romano), estabelecendo que o direito de ação ou a ação em si deveriam estar vinculados à existência de um direito material. A violação de referido direito que possibilitava a atuação em juízo, ou seja, "não há ação sem direito; não há direito sem ação; a ação segue a natureza do direito". 4

A crítica que se faz a referida teoria se dá principalmente em relação aos casos de demandas meramente declaratórias, em que se busca eventualmente apenas sedimentar ou declarar determinada situação, sem necessidade de vinculação direta a um direito material violado.

Por volta do ano de 1856, na Alemanha, surgiu uma importante discussão doutrinária acerca do tema do direito de ação. Tratam-se dos ensinamentos trazidos por Bernhard Windscheid e Thedor Muther. Enquanto Muther defendeu que o direito de ação refletia a actio romana e, como tal, representava um direito de tutela contra o Estado, Windscheid asseverou que a actio romana em verdade se coadunava com o conceito de “pretensão" existente à época no direito germânico (“Anspruch”).

No início do século XIX, o direito processual ainda se apresentava como acessório do Direito Civil, não possuindo a autonomia e importância que hoje se revela. Foi com a incorporação do Direito Romano na Europa, principalmente na Alemanha e posteriormente na Itália, que houve grande projeção do estudo do direito processual. ${ }^{5}$

A discussão travada entre Windscheid e Muther deu ensejo ao desenvolvimento das teorias autonomistas na Alemanha.

\footnotetext{
${ }^{4}$ CINTRA, Antonio Carlos de Araújo; Dinamarco, Cândido Rangel; Grinover, Ada Pellegrini. Teoria Geral do Processo. São Paulo: Editora Malheiros; 2007, p. 266.

${ }^{5}$ NERY JR., Nelson, Condições da Ação, Doutrinas Essenciais de Processo Civil, v. 2, São Paulo: Revista dos Tribunais, 2011, p. 179.
} 
A autonomia do direito de ação revelou-se originariamente na obra de Oskar von Bülow, em 1868, que tratava dos pressupostos processuais e exceções dilatórias (Die Lehre von den Einreden und die Prozessvoraussetzungen). Adolf Wach, em 1885, em obra bastante ampla, também contribuiu de forma relevante para a autonomia do direito processual, trazendo preceitos que foram utilizados pelos doutrinadores que o sucederam ${ }^{6}$.

Referidos autores (da teoria concretista) defendem o direito de ação como autônomo, público e concreto, sendo que para Wach o direito de ação corresponderia ao direito de uma tutela jurídica favorável, dirigida contra o Estado e contra a parte adversa que deve suportar os ônus da sentença. Já para Bülow o direito corresponderia a uma sentença justa.

Seguindo na linha de Wach, Chiovenda também apresentou sua teoria da ação como direito autônomo. Nada obstante, defendeu que a ação é direito potestativo, dirigido à parte adversa e não ao Estado. Segundo Chiovenda o direito de ação reflete a possibilidade de a parte obter tutela jurisdicional em face de outrem, sem que este possa evitar tal intento. ${ }^{7}$

Na mesma linha de Chiovenda, Calamandrei também defendeu o direito de ação como direito potestativo. Referido autor trouxe algumas inovações à tese, asseverando que caberá ao magistrado verificar se o autor da demanda possui razão ou não, sendo que o fato de o autor ter razão não se apresenta mais como pressuposto de seu direito. ${ }^{8}$

Poucos anos antes da edição da obra de Wach, dois doutrinadores também se destacaram por trazerem teses inovadoras em relação às vigentes à época até então. Heinrich Degenkolb, em 1877 (Einlassungszwang und Urteilsnorm), e Alexander Plósz, em 1980 (Beiträge zur Theorie des Klagerechts) defenderam o direito de ação como direito autônomo, que não se confunde com o direito material cuja tutela se busca em juízo. Nesse

\footnotetext{
6 ALVIM, Arruda. Substituição Processual, Prova escrita em concurso de livre-docência. Doutrinas Essenciais de Processo Civil, v. 3, São Paulo: Revista dos Tribunais, 2011, p. 435.

${ }^{7}$ CINTRA, Antonio Carlos de Araújo; Dinamarco, Cândido Rangel; Grinover, Ada Pellegrini. Teoria Geral do Processo. São Paulo: Editora Malheiros; 2007, p. 267-269.

8 SILVA, Ovídio Araújo Baptista da. Teoria Geral do Processo Civil, 6a ed., São Paulo: Revista dos Tribunais, 2011, p. 89.
} 
passo, independentemente de possuir razão em seu pleito, o autor possui direito de exigir um pronunciamento do Estado em relação à questão posta no processo, independentemente de possuir um direito subjetivo material merecedor de tutela. O direito de ação, portanto, seria abstrato, subjetivo e público, circunstância que gerou a denominação de referida tese como teoria do direito abstrato. ${ }^{9}$

Na Itália, a teoria foi desenvolvida por Alfredo Rocco (La Sentenza Civile), que acrescentou à teoria o entendimento de que o direito de ação estava vinculado a um interesse (primário) que deve ser tutelado pelo direito. Rocco aduz, ainda, sobre um interesse secundário, relacionado ao interesse na intervenção do Estado, mas ressalva que o interesse primário é suficiente para configuração do direito de ação.

Outros doutrinadores também colaboraram com referida teoria, como Ugo Rocco, que trouxe o direito de ação sob dois enfoques: plano formal, relacionado ao direito da parte de exigir do Estado a tutela de seu direito e o plano substancial, que se refere ao interesse que a parte possui na intervenção do Estado e defesa seus direitos. Francesco Carnelutti, Eduardo Couture e Emilio Betti também trataram do tema, asseverando a autonomia do direito de ação em relação ao direito material, porém cada um com peculiaridades específicas. ${ }^{10}$

Com o passar dos anos, os autores perceberam que o direito de ação não poderia estar ligado à efetiva procedência da lide, ou seja, à existência de razão do proponente da lide. Nesse passo, as teorias passaram a se desenvolver não apenas com relação à autonomia do direito de ação em si, mas com relação ao fato de a ação representar um direito de tutela, seja ele positivo ou negativo quando do julgamento do feito.

Exatamente nesse sentido o ensinamento de Enrico Tullio Liebman, ao definir o direito de ação com um direito à sentença de mérito, sendo este público, subjetivo e instrumental. Segundo sua teoria, as condições se prestariam para verificação da existência

\footnotetext{
9 SANTOS, Moacyr Amaral, Primeiras Linhas de Direito Processual Civil, 29a ed, vol. I, São Paulo: Saraiva, 2012, p. 195.

${ }^{10}$ TUCCI, Rogério Lauria, Aspectos Modernos do Conceito de Ação, Doutrinas Essenciais de Processo Civil, v. 2, São Paulo: Ed. RT, 2011, p. 59.
} 
do direito de ação, sendo que o não preenchimento de alguma delas implicaria o julgamento sem resolução do mérito. ${ }^{11}$

Os ensinamentos de Liebman permearam o direito brasileiro, influenciando-o sobremaneira. A sua teoria eclética inspirou autores como José Frederico Marques e Moacyr Amaral Santos, que defendem o direito subjetivo de ação como aquele relativo à possibilidade de obtenção de tutela jurisdicional, objetivando uma decisão de mérito.

Desta forma, os doutrinadores pátrios, desvinculando-se da teoria clássica, defenderam também a autonomia do direito de ação em relação ao direito material. Tal conceito é até hoje o entendimento doutrinário dominante em nosso país. ${ }^{12}$

A partir de tal premissa (autonomia do direito de ação), os doutrinadores passaram então a delimitar o direito de ação e os requisitos para seu exercício.

O direito de ação foi instituído, na $\mathrm{CF} / 88$, como garantia fundamental (art. 5 $\mathrm{XXXV}, \mathrm{CF}$ ), porém notoriamente seu exercício não está livre da análise de requisitos específicos para tal fim.

Para análise de tais requisitos, entretanto, faz-se necessária uma breve distinção entre as teorias que tratam das condições da ação.

Parte da doutrina defende a teoria do binômio, em que as questões relativas ao processo são divididas em: admissibilidade e mérito. A doutrina alemã é defensora de tal posição ${ }^{13}$, sendo que alguns doutrinadores brasileiros, como Fredie Didier Jr. e até mesmo Candido Dinamarco (após evolução de seu entendimento) ${ }^{14}$, têm adotado referido posicionamento. Para referidos autores, inexistiria a categoria de condições da ação como instituto autônomo. Nesse passo, a análise quanto à legitimidade da parte, interesse

${ }^{11}$ LIEBMAN, Enrico Tullio. Manual de Direito Processual Civil, vol. I, Rio de Janeiro: Forense, 1984, p. $150-151$.

${ }^{12}$ MARQUES, José Frederico. Instituições de Direito Processual Civil, $4^{\text {a }}$ ed., v. 2, Rio de Janeiro: 1971, p. 25 e 26.

${ }^{13}$ BARBOSA MOREIRA, José Carlos. Sobre pressupostos processuais. Temas de direito processual, São Paulo: Saraiva, 1989. p. 83-84.

${ }^{14}$ DINAMARCO, Cândido Rangel. Instituições de direito processual civil. São Paulo: Malheiros, 2001. vol. 3, p. 128; Instituições de direito processual civil. São Paulo: Malheiros, 2001. vol. 2, n. 727, p. 616-618. 
processual e possibilidade jurídica do pedido se encontrariam como requisitos de admissibilidade ou questões de mérito, conforme o entendimento doutrinário a que se filie.

Há doutrinadores que correlacionam legitimidade da parte, interesse processual e possibilidade jurídica do pedido como figuras ligadas ao próprio mérito da causa, sendo que, para análise de tais elementos, o juiz necessitaria adentrar no mérito, apesar de produzir decisão terminativa (nos termos do Código de Processo). Outros autores, ainda, defendem que a decisão a ser proferida deveria ser de improcedência da lide, como é o caso de Fredie Didier ${ }^{15}$, razão pela qual referido autor assevera que o Código de Processo deveria ser alterado nesse ponto específico.

Por outro lado, há doutrinadores que, apesar de defenderem o binômio, asseveram que referidos conceitos integrariam os pressupostos de admissibilidade. Para eles, a legitimidade, interesse e possibilidade jurídica do pedido seriam questões anteriores ao mérito e implicariam o proferimento de decisão sem a necessidade de análise do direito material envolvido, ou seja, seriam alheias à análise do mérito da causa.

Verifica-se, pois, que, apesar da adoção do binômio, as condições da ação em si não deixam de existir ou de serem analisadas. O que ocorre é apenas a sua supressão como requisito autônomo, sendo que as figuras da legitimidade da parte, do interesse processual e da possibilidade jurídica do pedido "seriam examinadas ou como questões de mérito (possibilidade jurídica do pedido e legitimação ad causam ordinária) ou como pressupostos processuais (interesse processual e legitimação extraordinária)". ${ }^{16}$

Nada obstante tal entendimento, a corrente doutrinária majoritária no Brasil defende a teoria do trinômio. É este também o posicionamento do atual Código de Processo Civil, que estabelece três categorias distintas e específicas: pressupostos processuais, condições da ação e questões de mérito.

Os pressupostos processuais podem ser subjetivos ou objetivos (extrínsecos e intrínsecos). Os pressupostos subjetivos relacionam-se ao juiz ou às partes (competência,

\footnotetext{
${ }^{15}$ DIDIER JR., Fredie. Será o fim da categoria "condição da ação"? Um elogio ao projeto do novo Código de Processo Civil, Doutrinas Essenciais de Processo Civil. vol. 2. São Paulo: Ed. RT, out 2011, p. 323.

${ }^{16}$ Ibidem, p. 323.
} 
imparcialidade, capacidade postulatória, entre outros). Os pressupostos objetivos extrínsecos conectam-se à relação processual (coisa julgada, litispendência, existência de cláusula ou compromisso arbitral, entre outros). Por fim, os pressupostos objetivos intrínsecos relacionam-se às questões formais da própria ação (citação válida, recolhimento de custas, adequação da peça inicial, entre outros).

As condições da ação são majoritariamente reconhecidas como: a legitimidade da parte, o interesse processual e a possibilidade jurídica do pedido. Como se verá a seguir, muito se discute quanto ao reconhecimento da possibilidade jurídica como condição da ação, sendo esta muitas vezes aduzida como reflexo do interesse processual.

As condições da ação não seriam questões de mérito nem propriamente questões de admissibilidade.

Sobre o ponto, importante o ensinamento de Ada Pellegrini Grinover, ao afirmar que "o fenômeno da carência de ação nada tem a ver com a existência do direito subjetivo afirmado pelo autor, nem com a possível inexistência dos requisitos, ou pressupostos, da constituição da relação processual válida. É situação que diz respeito apenas ao exercício do direito de ação e que pressupõe a autonomia desse direito".

Desta forma, "incumbe ao juiz, antes de entrar no exame do mérito, verificar se a relação processual, que se instaurou, desenvolveu-se regularmente (pressupostos processuais) e se o direito de ação pode ser validamente exercido, no caso concreto (condições da ação)" ${ }^{\prime 17}$.

Por essa razão "quer os pressupostos processuais, quer as condições da ação são requisitos prévios, cuja inobservância impede que o juiz chegue ao conhecimento e julgamento do mérito; mas com o mérito não se confundem: nada têm a ver com a eventual existência do direito subjetivo material afirmado pelo autor. É exatamente isto que é preciso ter em mente, ao delinear e classificar as condições da ação". ${ }^{18}$

\footnotetext{
${ }^{17}$ THEODORO JR., Humberto, Curso de Direito Processual Civil, v. I, $20^{\mathrm{a}}$ ed., Rio de Janeiro: Forense, p. 52.

${ }^{18}$ GRINOVER, Ada Pellegrini, As condições da ação penal. Revista Brasileira de Ciências Criminais, v. 69, 2007, pp. 179-199.
} 
Em vista da grande dificuldade de se reconhecer a legitimidade e o interesse processual de forma autônoma e livres do mérito da demanda, foi adotada majoritariamente no Brasil a teoria da asserção para fins de tal distinção, pela qual as condições da ação são apuráveis de plano, através da mera leitura da peça apresentadas pelas partes, sem necessidade de averiguação de questões materiais específicas da lide. Ausentes tais condições, é proferida decisão terminativa sem resolução do mérito. Ou seja, aquilo que necessitar de exame de provas vai além das condições da ação e exige decisão de mérito (com trânsito em julgado material).

Sobre o ponto, Kazuo Watanabe traz relevante anotação, mencionando que "o ponto nodal da problemática está em saber se as condições da ação (rectius: "condições para o julgamento do mérito") devem ser aferidas segundo a afirmativa feita pelo autor na petição inicial (in statu assertionis) ou conforme seu elo efetivo com a 'situação de fato contrária ao direito' que vier a ser evidenciado pelas provas produzidas pelas partes". ${ }^{19}$

Alfredo Buzaid defende a existência de condições de admissibilidade do julgamento da lide, que não se confundem com o mérito da lide:

Para que o juiz possa chegar ao termo último da ação e proferir sentença definitiva, é preciso que concorram, na formação e desenvolvimento do processo, várias condições, que denominamos de condições de admissibilidade do julgamento da lide. Com esta expressão designamos todas as condições necessárias para que o juiz possa conhecer do mérito da causa e decidir o conflito de interesse, dando razão a uma das partes e negando-a à outra. Não são condições de uma sentença qualquer, mas sim condições de uma sentença de mérito. Pode-se dividir, pois, todo o material que se apresenta ao conhecimento do Juiz em duas categorias fundamentais: de um lado, a lide; do outro lado, as condições de admissibilidade da lide. Concorrendo estas condições, o juiz julgará a lide; mas faltando alguma delas, o juiz proferirá uma sentença que implica a terminação do processo, sem lhe resolver o mérito. Estas condições de

${ }^{19}$ WATANABE, Kazuo. Da Cognição no Processo Civil, São Paulo: Ed. RT, 1987, p. 58. 
admissibilidade do julgamento da lide são variadas, heterogêneas e independentes entre si.

\section{(...)}

Não basta, para que seja decidida a lide, que o processo se tenha constituído e se tenha desenvolvido validamente. As partes podem estar regularmente representadas e o juiz ser competente. Pode não ter ocorrido nenhum motivo que autorize a absolvição da instância. Mas tudo isso ainda não habilita o juiz a dar ingresso no conhecimento do mérito. É que, além dos requisitos concernentes à validade do processo e à inexistência de impedimentos, deve o juiz verificar se concorrem as condições de admissibilidade da ação. A ação pode ser inadmissível, por lhe faltar qualquer de suas condições, ainda que o processo seja regular e válido. ${ }^{20}$

Parece mais adequada exatamente a corrente doutrinária que adota o trinômio para fins de definição das condições da ação, muito embora, como se verá, há certa razoabilidade na proposição de exclusão da possibilidade jurídica do pedido como condição da ação.

\subsection{A Possibilidade Jurídica do Pedido}

O direito brasileiro estabelece as condições da ação nos arts. $3^{\circ}$ e 295 , incisos I e II, do Código de Processo Civil. Nestes há remissão expressa apenas à necessidade de legitimidade e interesse para que o indivíduo possa propor uma demanda em juízo e como requisitos para a regularidade da petição inicial. Nada obstante tal disposição, o art. 267, VI, do CPC complementa o rol de condições da ação, trazendo a possibilidade jurídica do pedido também como causa para extinção do processo sem resolução do mérito.

Como já visto anteriormente neste trabalho, a doutrina pátria predominante, em consenso com as disposições do Código de Processo, aduz a autonomia das condições da

${ }^{20}$ BUZAID, Alfredo. Do agravo de petição no sistema do Código de Processo Civil. $2^{\mathrm{a}}$ ed. São Paulo: Saraiva, 1956, p. 115-121. 
ação, a par dos pressupostos processuais e da análise do mérito da demanda. Tal entendimento pautou-se nos ensinamentos de Liebman.

Ocorre que, muitos doutrinadores e inclusive o legislador pátrio não se ativeram ao fato de que Liebman, a partir da terceira edição de seu manual de direito processual, passou a definir apenas duas condições da ação, quais sejam, o interesse processual e a legitimidade da parte, remanescendo silente quanto à possibilidade jurídica, que constava das duas primeiras edições da obra por editada. Tal alteração de entendimento decorreu exatamente por conta do fato de que seu único exemplo de impossibilidade jurídica se tratava do divórcio, cuja figura jurídica inexistia à época na Itália. Com a alteração normativa italiana que passou a prever o divórcio, Liebman acabou por alterar sua teoria, trazendo novo entendimento no qual a possibilidade jurídica foi deixada de lado.

O conceito de pedido juridicamente possível está relacionado à ausência de proibição normativa quanto ao pedido formulado. Importante mencionar que, na teoria de Liebman, a impossibilidade jurídica era analisada de forma abstrata e autônoma. Ou seja, o pedido em si deveria ser contrário ao ordenamento jurídico. No entanto, referido pensamento fora alvo de críticas, como é o caso de Calmon de Passos. Referido autor, como outros, passou a defender que a possibilidade jurídica deveria ser analisada não apenas em relação ao pedido, mas também à situação que o envolve, sendo que este, assim, deveria ser analisado conjuntamente com a causa de pedir.

Sobre o tema, Rodolfo de Camargo Mancuso ensina que:

Normalmente, a possibilidade jurídica do pedido é concebida como a necessidade de previsão, in abstracto, no ordenamento jurídico, da pretensão formulada pela parte. O que bem se compreende porque, sendo nosso sistema jurídico filiado à legalidade estrita, cabendo ao juiz fazer a subsunção do fato à norma (da mihi factum dabo tibi jus), tal atividade ficaria inviável, à míngua de texto legal que previsse, mesmo que genericamente, a pretensão formulada pelo autor. ${ }^{21}$

\footnotetext{
${ }^{21}$ MANCUSO, Rodolfo de Camargo. Ação Popular, $2^{\text {a }}$ ed., São Paulo: Ed. Revista dos Tribunais, 1996, pp. 117-118.
} 
Já Calmon de Passos assevera que "não se pode abstrair da causa de pedir para a construção do conceito de possibilidade jurídica" 22

Calmon de Passos defende, inclusive, a supressão da categoria da possibilidade jurídica do pedido ${ }^{23}$, assim como o fez Fredie Didier ${ }^{24}$. Outros autores defenderam também a análise da possibilidade jurídica como questão de mérito, que exigiria uma decisão que gere coisa julgada material $^{25}$.

Para Calmon de Passos, no que concerne especificamente à tutela de direitos coletivos, a impossibilidade jurídica não merece ser destacada de forma autônoma, vez que estaria ora relacionada à legitimação, ora ao interesse processual. Para ele:

Esta "invenção nacional" carece de maior relevo no tocante ao mandado de segurança coletivo. Não constituindo hipótese de inépcia (impossibilidade relativa), a impossibilidade jurídica sempre envolverá ou um problema de legitimação ou um problema de interesse processual.

No Brasil, o exemplo clássico quanto à impossibilidade jurídica se trata da dívida de jogo. Importante mencionar que, embora o pedido (cobrança de dívida) seja legalmente permitido, analisando a causa de pedir (dívida de jogo), conclui-se pela impossibilidade de sua formulação em juízo (art. 814, do CC).

Nesse passo, o que parece mais razoável é que, quanto à possibilidade jurídica do pedido, em grande parte dos casos, para realizar o julgamento o juiz deve, a priori, conhecer do mérito da lide. Desta forma, em consonância com Fredie Didier, parece razoável a supressão de referida categoria, mas com uma análise conforme o caso concreto, gerando decisão terminativa ou de julgamento de mérito segundo se exija ou não exame da relação material envolvida na lide.

${ }^{22}$ CALMON DE PASSOS, José Joaquim. Em torno das condições da ação: a possibilidade jurídica do pedido, Revista de Direito Processual Civil, vol. 4, Rio de Janeiro: Saraiva, 1964, p. 63.

${ }^{23}$ Ibidem, pp. 61-62.

24 DIDIER JR, Fredie. Possibilidade jurídica do pedido: um novo enfoque do problema - Pela proscrição. Revista de Direito Processual Civil, vol. 13. n. 13, Curitiba: Gênesis, 1999, pp. 449-463.

${ }^{25}$ OLIVEIRA, Eduardo Ribeiro de. Condição da Ação: a possibilidade jurídica do pedido, Doutrinas Essenciais de Processo Civil, v. 2, São Paulo: Ed. RT, 2011, p. 135. 
Para Didier, a justificativa para a exclusão da possibilidade jurídica seria exatamente a necessidade de se resolver definitivamente a controvérsia, através de uma sentença de improcedência, com trânsito em julgado.

O projeto de Código de Processo Civil (PLC 8.046/2010), ora em fase de aprovação na Câmara dos Deputados, tomou caminho intermediário ao excluir a possibilidade jurídica do pedido do rol de condições da ação, que, segundo o entendimento de alguns autores, passaria agora a ser analisada como questão de mérito ${ }^{26}$. Nesse sentido, dispõe o art. 495, do PLC 8.046/2010 que "o juiz proferirá sentença sem resolução de mérito quando: (...) ‘inciso VI.' verificar ausência de legitimidade ou de interesse processual.”

Segundo Fredie Didier, nos termos do projeto, a sentença que reconhecer a impossibilidade jurídica deverá reconhecer a improcedência do pleito do autor.

Referido entendimento é, no entanto, combatido por Alexandre Freitas Câmara. ${ }^{27} \mathrm{O}$ autor assevera que a impossibilidade jurídica deveria ser tratada como falta de interesse processual, vez que se trataria de providência jurisdicional sem utilidade, razão pela qual daria ensejo a sentença terminativa, sem julgamento do mérito. Para ele, referido pensamento estaria em consonância com a teoria da asserção.

A segunda alteração ocorrida, no entendimento de Didier, seria a de que teria sido banida de nosso ordenamento a categoria das "condições da ação", vez que o dispositivo legal não mais traria referência a tal instituto. Assim, as decisões ora proferidas quanto à legitimidade e interesse processual estariam relacionadas a questões de admissibilidade, ou seja, à categoria pressupostos processuais. A legitimidade seria pressuposto de validade subjetivo relativo às partes, enquanto o interesse seria pressuposto de validade objeto intrínseco. $^{28}$

\footnotetext{
${ }^{26}$ DIDIER JR, Fredie. Será o fim da categoria "condição da ação"? Um elogio ao projeto do novo Código de Processo Civil, Doutrinas Essenciais de Processo Civil. vol. 2. São Paulo: Ed. RT, out 2011, p. 323.

${ }^{27}$ CÂMARA, Alexandre Freitas. Será o Fim da "Condição da Ação"? Uma Resposta a Fredie Didier Jr., Revista de Processo, v. 197, São Paulo: Ed. RT, 2011, p. 263.

${ }^{28}$ DIDIER JR., Fredie. Será o fim da categoria "condição da ação"? Um elogio ao projeto do novo Código de Processo Civil, Doutrinas Essenciais de Processo Civil. vol. 2. São Paulo: Ed. RT, out 2011, p. 323.
} 
Alexandre Freitas Câmara discorda de Didier também nesse ponto. O jurista aduz que, ainda que o projeto não mencione expressamente a categoria "condições da ação", é necessário o reconhecimento do referido instituto como autônomo em relação aos pressupostos processuais. As condições da ação, embora requisito ligado à admissibilidade, seria conceito heterogêneo em relação ao pressuposto processual.

Sobre o tema, Leonardo Carneiro da Cunha assevera que "a possibilidade jurídica do pedido e a legitimidade ordinária da parte passariam (...) a ser questões de mérito. Ao lado das questões de mérito, haveria os pressupostos processuais em cujo âmbito estariam inseridos o interesse de agir e a legitimidade extraordinária". ${ }^{29}$

\subsection{Interesse processual}

Referido instituto foi por vezes denominado pelos doutrinadores como "interesse de agir", denominação esta que, a nosso ver e de outros tantos doutrinadores, não deve prosperar atualmente. Enquanto a nomenclatura "interesse processual" demonstra a característica da eficácia do requisito dentro de um processo, o "interesse de agir" sugere conceito também extraprocessual, o que não se coaduna com o objeto do preceito em referência.

O requisito do interesse processual é qualificado pela doutrina como um binômio entre necessidade e utilidade ou, nos termos dos ensinamentos de Candido Dinamarco ${ }^{30}$, pelo binômio necessidade e adequação.

Refere-se, pois, à necessidade de se buscar junto ao Estado um provimento jurisdicional, no intuito de se afastar uma lesão ou proteger um direito já violado e a utilidade/adequação de referido provimento. Desta forma, o primeiro elemento vincula-se à atividade jurisdicional, mover o Estado para a proteção determinada tutela. Já o segundo elemento se relaciona ao provimento almejado em si, que deve ser útil.

\footnotetext{
${ }^{29}$ CUNHA, Leonardo Carneiro da. Será o fim da categoria condições da ação? uma intromissão no debate travado entre Fredie Didier Jr. e Alexandre Freitas Câmara, Revista de Processo, v. 198, São Paulo: Ed. RT, 2011, p. 235.

${ }^{30}$ DINAMARCO, Cândido Rangel. Execução Civil, São Paulo: Ed. RT, 1973, p. 140-150.
} 
Para Liebman, "o interesse de agir é o elemento material do direito de ação e consiste no interesse em obter o provimento solicitado", sendo que o "interesse de agir decorre da necessidade de obter através do processo a proteção do interesse substancial; pressupõe, por isso, a assertiva de lesão deste interesse e a aptidão do provimento do pedido a protegê-lo e satisfazê-lo". ${ }^{31}$

Moacyr Amaral Santos ensina que o interesse processual "é um interesse secundário, instrumental, subsidiário, de natureza processual, consistente no interesse ou necessidade de obter uma providencia jurisdicional quanto ao interesse substancial contido na pretensão". 32

Na mesma linha, Rodolfo de Camargo Mancuso esclarece que:

Hoje está razoavelmente assente que o interesse de agir se caracteriza pela necessidade ou pela utilidade que a ação se representa pela parte que se afirma titular do direito ou interesse (material) em causa; e ainda se poderia acrescentar o quesito da adequação da via processual eleita, porque, naturalmente, não tem interesse processual (que é um interesse jurídico) a parte que se equivocou grosseiramente na escolha da ação cabível, porque já não poderá o juiz adentrar o mérito, em face da inidoneidade do meio processual eleito. ${ }^{33}$

Segundo Buzaid é importante distinguir o interesse processual do interesse material:

O Código escreve que para propor ou contestar ação é necessário legítimo interesse econômico ou moral (...). Embora esta forma legal não seja digna de encômios, a finalidade da lei foi realmente restringir-lhe o conceito unicamente ao interesse processual, cujo controle também é feito no despacho saneador. Diz-se que o interesse

\footnotetext{
${ }^{31}$ LIEBMAN, Enrico Tullio, Manual de Direito Processual Civil, vol. I, Rio de Janeiro: Ed. Forense, 1984, p. 154-155.

32 SANTOS, Moacyr Amaral. Primeiras linhas de direito processual civil - v. 1 . 21. ed. São Paulo: Saraiva, 1999, p. 170.

33 MANCUSO, Rodolfo de Camargo. Ação popular - proteção ao erário, do patrimônio público, da moralidade administrativa e do meio ambiente, $5^{\mathrm{a}}$ ed., v. 1, São Paulo: Revista dos Tribunais, 2003, p. 136.
} 
é legítimo quando se funda na lei. Ora, o interesse que o juiz aprecia no despacho saneador é especificamente processual e consiste na necessidade de recorrer ao Poder Judiciário a fim de não sofrer um dano injusto (...). O interesse processual é o que justifica o ingresso em juízo. O interesse material é, ao contrário, aquele que está na essência do direito subjetivo e justamente por isso pode ser lícito ou ilícito, moral ou imoral. Desta distinção entre as duas espécies de interesse decorre importante consequência jurídica. O julgamento do interesse material é decisão de mérito enquanto que o julgamento do interesse processual se cinge a uma das condições de admissibilidade da ação ${ }^{34}$

Nesse passo, nos termos da legislação pátria (arts. $3^{\circ}$ e $6^{\circ}$ do $\mathrm{CPC}$ ), o interesse processual está ligado à relação de direito material violada, verificada no seio do processo judicial, sendo parte legítima aquela que teve seu direito atingido ou ameaçado, que é exatamente aquele que possui interesse de agir em juízo.

José Frederico Marques, nessa linha, ensina que consiste a "legitimidade ad causam (...) na individualização daquele a quem pertence o interesse de agir...",35

Sobre o ponto, importante a lição de Rodolfo de Camargo Mancuso, no sentido de que "há hipóteses em que o interesse processual e a legitimação para agir quase se 'superpõem'; a interação é notável, tornando difícil a distinção". ${ }^{36}$

Por esta razão, na ação individual, o interesse é avaliado em relação ao direito individual objeto de violação e sua tutela em juízo. Assim, falta interesse, por exemplo, para execução de título extrajudicial, àquele que apresenta em juízo cheque prescrito. Por outro lado, referido indivíduo possui interesse processual no ajuizamento de uma demanda monitória. Veja-se que, na primeira hipótese apresentada, não se verifica utilidade, tampouco adequação no provimento judicial almejado.

\footnotetext{
${ }^{34}$ BUZAID, Alfredo. Do Despacho Saneador, Estudos de Direito, v. 1, São Paulo: Saraiva, 1972, pp. 41- 42. ${ }^{35}$ MARQUES, José Frederico, Manual de Direito Processual, v. 1, 7. a ed., São Paulo: Ed. Saraiva, 1980, p. 178.

${ }^{36}$ MANCUSO, Rodolfo de Camargo. Ação civil pública - em defesa do meio ambiente, do patrimônio cultural e dos consumidores. 9. ed. São Paulo: Revista dos Tribunais, 2004, p. 59.
} 
No que concerne especificamente à ação coletiva, a análise do interesse também possui relação direta com o direito material violado, cujo provimento jurisdicional se busca a tutela estatal.

Há, contudo, divergência doutrinária quanto à necessidade de verificação do interesse exclusivamente em relação ao substituído (titular do direito violado), ou se também deveria ser avaliado o interesse de cada um dos legitimados, conforme as situações concretas se apresentem.

Para Chiovenda, a análise da relação entre o substituído e o substituto é feita para fins do interesse da substituição processual e não do interesse como condição da ação ${ }^{37}$.

Nesse mesmo sentido Hermes Zaneti Jr. defende que o "interesse em substituição processual é diverso do interesse processual e do interesse material do substituído, revelando-se como a relação entre substituto e substituído".38

Calmon de Passos assevera que o interesse na ação coletiva (mais especificamente no mandado de segurança coletivo) não possui relação com a pretensão do ente que ingressa com a demanda (impetrante), mas sim com os substituídos "e isso precisa ser cabalmente demonstrado".39

Por outro lado, Teori A. Zavascki aduz a necessidade de se avaliar o interesse do substituto processual, que deveria possuir interesse processual próprio, nos termos do art. $3^{\circ}$ do CPC. Referido jurista defende que deve haver uma "relação de pertinência e compatibilidade entre a razão de ser do substituto e o conteúdo do direito subjetivo do substituído, objeto da demanda". ${ }^{40}$

\footnotetext{
${ }^{37}$ CHIOVENDA, Giuseppe. Principii di direito processuale civile, $3^{\mathrm{a}}$ ed., Roma, 1923, p. 597.

${ }^{38}$ ZANETI JR., Hermes. Mandado de Segurança Coletivo - Aspectos Controversos, Porto Alegre: Ed. Sergio Antonio Fabris, 2001, p. 138.

${ }^{39}$ CALMON DE PASSOS, José Joaquim. Mandado de Segurança Coletivo, Mandado de Injunção e Habeas Data - Constituição e Processo, Rio de Janeiro: Forense, 1989, pp. 34-35.

${ }^{40}$ ZAVASCKI, Teori Albino. Defesa de direitos coletivos e defesa coletiva de direitos, Revista Jurídica, $\mathrm{n}^{\circ}$ 212, Porto Alegre, 1995, p. 23
} 
A crítica que se faz a referido autor é a de que o interesse por ele descrito seria o interesse material e não o interesse processual descrito pela lei processual. Porém, concorda-se em parte com a afirmação deste, vez que o cotejo do interesse processual na ação coletiva deve ser analisado em conjunto com a representação adequada e respectiva pertinência temática. Assim, a utilidade do provimento dos partidos políticos, sindicatos e entidades associativas e, por conseguinte, seu interesse processual, possuirá relação com o objeto de cada um deles, sendo o dos partidos políticos: o cumprimento da legalidade, o do sindicato: a tutela de direito da sua classe específica e o das entidades associativas: a tutela de pretensão de seus associados, todos eles através de provimento e procedimento adequados.

Inovando referidos entendimentos doutrinários, Antonio do Passo Cabral critica o conceito clássico de interesse de agir, asseverando que tal acepção está conexa à violação de um direito material específico, para fins de um processo voltado para a sentença condenatória. ${ }^{41}$ Referido autor propõe, pois, uma interpretação contemporânea ao interesse de agir, criticando o fato de o interesse, quando entendido como binômio "necessidade $\mathrm{x}$ utilidade", permitir a confusão entre mérito e condição da ação.

Pautado em tais afirmações, Cabral propõe a ampliação do conceito de interesse processual, a partir de um conceito de "zona de interesse" para cada ato ou posição processual, ocorrendo uma aplicação dinâmica do interesse de agir.

A par de tal discussão, é certo que no mandado de segurança o interesse processual “decorre da necessidade de usar o remédio constitucional para afastar a lesão já consumada a direito público subjetivo do impetrante, ou obstar a consumação de lesão, da qual se tem justo receio". ${ }^{42}$ A utilidade no mandado de segurança coletivo se refere ao provimento que se busca em relação aos titulares do direito violado ou ameaçado por ato ilícito ou cometido com abuso de poder. A adequação está relacionada à existência de direito líquido e certo a ser protegido, bem como à sua natureza pública, cuja violação esteja devidamente demonstrada pela prova pré-constituída.

\footnotetext{
${ }^{41}$ CABRAL, Antonio do Passo. Despolarização do processo e "zonas de interesse": sobre a migração entre os polos da demandas, in O Novo Processo Civil Brasileiro - Direito em Expectativa, Rio de Janeiro: Ed. Forense, 2011, pp. 162-170.

${ }^{42}$ CALMON DE PASSOS, José Joaquim. Mandado de Segurança Coletivo, Mandado de Injunção e Habeas Data - Constituição e Processo, Rio de Janeiro: Forense, 1989, pp. 34-35.
} 


\subsection{Legitimidade}

Segundo Candido Dinamarco, a legitimidade é "a qualidade para estar em juízo, como demandante ou demandado, em relação a determinado conflito trazido ao exame do juiz". 43

A regra geral estabelecida pelo código de processo brasileiro para tutela do direito material em juízo é exatamente a titularidade em relação a referido direito. Nesse sentido, o art. $6^{\circ}$ do CPC estabelece que "ninguém poderá pleitear, em nome próprio, direito alheio, salvo quando autorizado por lei”. Contudo, a disposição em referência traz exceção específica, relativa aos casos em que houver expressa previsão legal em contrário, permitindo a legitimação daquele que não foi o titular do direito.

Dentro do conceito da doutrina processual clássica, a busca de um provimento jurisdicional se apresenta com um caráter individual, em que o efetivo titular do direito seria o único legitimado para a busca da proteção estatal de referido direito. Esta é a denominada "legitimação ordinária".

A ideia original do processo clássico era a pacificação de conflitos individuais, de forma que a legitimação era considerada sob esse viés específico.

Nada obstante tal pensamento, a evolução doutrinária e legislativa trouxeram figuras diversas da legitimação ordinária. O desenvolvimento social e da tutela de direitos, que será melhor abarcada em capítulo específico, traz à cena questões de natureza coletiva, em que o bem objeto da violação atinge mais de um indivíduo ou em que os indivíduos atingidos se conectam de alguma forma.

As figuras existentes no processo civil tradicional, contudo, não atendiam a tais situações específicas, o que deu ensejo à produção doutrinária e normativa com o intuito de autorizar determinadas pessoas ou entidades a buscar o provimento jurisdicional em favor da tutela dos direitos coletivos.

${ }^{43}$ DINAMARCO, Cândido Rangel. Instituições de Direito Processual Civil, II, $2^{\mathrm{a}}$ ed. São Paulo: Malheiros, 2002, p. 306 
A legitimação extraordinária de alguns entes ou pessoas para tutela judicial do direito de terceiros, seja em nome próprio (substituição processual), seja em nome do titular do direito violado (representação) surgiu como forma de suprir tal necessidade. Nesses casos (de legitimação extraordinária), a parte legitimada não se afirmará como titular do direito material a ser protegido. Ao contrário, trará requisitos (via de regra normativos) que demonstrem e deem substrato à sua condição de legitimado a compor a lide como parte na defesa do direito de um terceiro.

Há, entretanto, divergência doutrinária no que concerne à legitimação em sede de ação coletiva. Embora muitos autores defendam a teoria da substituição processual, como espécie da legitimação extraordinária nas ações coletivas no Brasil, é de se notar que existem outros dois posicionamentos, quais sejam: a legitimação autônoma e a legitimação ordinária das entidades. Tais teorias são fruto do fato de (i) a Constituição e a legislação ordinária preverem expressamente os legitimados, principalmente no que concerne ao mandado de segurança coletivo, o que redunda na interpretação doutrinária da existência de uma legitimação autônoma desses entes, desvinculada do direito material, (ii) da ideia de que as entidades possuem interesses próprios, atrelados aos interesses dos seus "representados", e de acordo com seus objetivos institucionais.

Calmon de Passos é defensor da teoria da substituição processual, afirmando que "a entidade impetrante do writ é substituta processual dos titulares dos interesses em causa e como tal deve ser tratada". ${ }^{4}$ Nesse mesmo sentido Barbosa Moreira, ao aduzir a ocorrência de substituição processual do legitimado extraordinário em relação ao titular do direito violado ou ameaçado. A parte, nesse caso, não se afirma titular do direito material.

Como o substituto não é titular do direito cuja tutela se busca em juízo, este não pode transacionar a respeito do direito, tampouco renunciá-lo. O legitimado extraordinário pode tão somente versar a respeito de questões procedimentais, como provas, interposição de recursos, etc.

\footnotetext{
${ }^{44}$ CALMON DE PASSOS, José Joaquim. Mandado de Segurança Coletivo, Mandado de Injunção e Habeas Data - Constituição e Processo, Rio de Janeiro: Forense, 1989, pp. 31-32.
} 
Celso Agrícola Barbi defende a legitimação anômala ou substituição processual, como exceção à regra do art. $6^{\circ}$ do $\mathrm{CPC} .^{45}$

Por outro lado, Rodolfo Mancuso assevera que, ainda que para defesa de direitos coletivos, haveria legitimação ordinária dos entes:

Temos que a legitimação para agir, nas ações que visam a tutela de interesses superindividuais, é de tipo ordinário, porque: a) quando o indivíduo age per se, na tutela de interesses gerais, ele também defende interesse próprio, configurado na 'cota-parte' daqueles interesses, a qual lhe pertence enquanto indivíduo, cidadão, eleitor ou contribuinte; é o que se passa, grosso modo, nas ações populares e nas class actions do Direito norte-americano. Não importa que, eventualmente, alguns integrantes da categoria ou da coletividade não se interessem pela ação ou discordem de seu objeto, porque aí não se trata de litisconsórcio necessário; o que releva é que o civis exerce a liberdade pública reconhecida uti singuli, de exigir uma administração proba e eficaz e o respeito à lei, conforme o caso; b) quando a tutela dos interesses superindividuais é feita através de grupos legalmente constituídos, a legitimação também é ordinária, na medida em que sustentam, em nome próprio, certas massas de interesses (ex.: os dos consumidores), para o que a lei os considerou idôneos. ${ }^{46}$

Kazuo Watanabe, nesse mesmo sentido, defende a legitimação ordinária dos entes na defesa dos direitos coletivos. ${ }^{47}$

Ada Pellegrini Grinover também defende a legitimação ordinária ${ }^{48}$. A jurista afirma que o ente que ajuíza a demanda coletiva, ao defender o interesse das pessoas cujos direitos foram atingidos, acaba por defender seus próprios objetivos institucionais. A jurista,

${ }^{45}$ BARBI, Celso Agrícola. Mandado de Segurança na Constituição de 1988, v. 16. Porto Alegre: Ajuris, 1989 , p. 48.

${ }^{46}$ MANCUSO, Rodolfo de Camargo, Interesses Difusos: Conceito e legitimação para agir. $5^{\text {a }}$ ed., São Paulo: Revista dos Tribunais, 2001, p. 192.

${ }^{47}$ WATANABE, Kazuo. Tutela jurisdicional dos interesses difusos: a legitimação para agir, In: A tutela dos interesses difusos. São Paulo: Max Limonad, 1984. p. 90.

${ }^{48}$ GRINOVER, Ada Pellegrini. Mandado de Segurança Coletivo: legitimação, objeto e coisa julgada, Revista de Processo, n 58, São Paulo: Ed. RT, 1990, p. 77, p. 101 
contudo, faz menção de que se deve analisar o caso concreto para fins de legitimação, e que com base nos princípios gerais do processo, pode-se falar em legitimação extraordinária definida pela constituição federal ${ }^{49}$.

Referidos autores propõem uma interpretação lata do disposto no art. $6^{\circ} \mathrm{CPC}$, aduzindo que a legislação estabelece expressamente a legitimação dos entes, cujos interesses institucionais são correlatos aos da classe, razão pela qual a tutela coletiva acaba por representar a própria defesa do objeto social da entidade.

A teoria da legitimação ordinária tem origem nas doutrinas italiana e alemã, que identificam a necessidade de proteção pelos indivíduos dos interesses e direitos próprios. Nesse passo, em referidos países, buscou-se legitimar o interesse das entidades para as demandas coletivas no objetivo institucional da entidade.

Nada obstante, entende-se que referida legitimação ordinária da entidade deve ser avaliada em conjunto com a "representatividade adequada", bem como com a pertinência temática do objeto social do ente em relação ao direito material objeto de tutela.

Há ainda, o entendimento doutrinário que defende o direito de conduzir o processo de forma autônoma. Nelson Nery Jr. aduz que a norma estabelece a possibilidade de um terceiro tutelar determinado direito material em juízo, sem que possua relação direta com referido direito. $\mathrm{O}$ direito de conduzir o processo seria independente do direito material a ser protegido. É o que se denominou de "legitimação autônoma para condução do processo".

Segundo os autores que defendem referida teoria, embora o legitimado defenda interesse alheio em nome próprio (condição peculiar da substituição processual), não seria possível ser identificado o titular do direito no caso de direitos coletivos e difusos. Nesse passo, não haveria como reconhecer quem seriam os atingidos pelo dano ambiental, os consumidores de água e energia, vez que não representariam grupo determinado ou reconhecível de indivíduos.

${ }^{49}$ Ibidem, p. 77. 
Já Ricardo de Barros Leonel defende a existência da legitimação autônoma para defesa dos interesses difusos e coletivos e a legitimação extraordinária, sob a espécie de substituição processual, quando se busca a tutela de direitos individuais homogêneos ${ }^{50}$ :

A posição que melhor se ajusta à identificação da natureza jurídica da legitimação para a defesa dos interesses difusos e coletivos é no sentido de que se trata de legitimação denominada autônoma para a condução do processo.

A legitimação autônoma não se confunde com a ordinária ou com a extraordinária. Parte de premissas distintas, e da peculiaridade de defesa em juízo de interesses que são, por natureza, indivisíveis e inerentes conjuntamente a toda uma coletividade, composta por membros indeterminados (na hipótese dos difusos) e eventualmente determináveis (na hipótese dos coletivos).

Esta questão comporta equação diversa quando se trata da tutela de interesses individuais homogêneos, o que fica patente é a substituição processual - legitimação extraordinária - em que os legitimados postulam em juízo interesse alheio, fazendo-o em nome próprio.

Sobre o ponto, a maioria da doutrina defende a legitimação extraordinária para fins de tutela dos direitos individuais homogêneos, mesmo aqueles que defendem a legitimação ordinária ou autônoma para a defesa de direitos difusos e coletivos. Nesse sentido, Nelson Nery Jr. ${ }^{51}$ :

\begin{abstract}
A ação coletiva para a defesa de direitos individuais homogêneos trata-se de hipótese de substituição processual, porque a lei legitimou outrem para a defesa em juízo, em nome próprio, de direito alheio cujo titular é identificável e individualizável.
\end{abstract}

No que concerne à legitimação extraordinária autônoma, alguns autores como Barbosa Moreira e Calmon de Passos, deram conotação diversa ao instituto, contrapondo-a

\footnotetext{
${ }^{50}$ LEONEL, Ricardo de Barros. Manual do processo coletivo. São Paulo: Ed. RT, 2002, p. 159.

${ }^{51}$ NERY JR., Nelson e ANDRADE NERY, Rosa Maria. Código de Processo Civil comentado e legislação processual civil extravagante em vigor. 3a ed.., São Paulo: Ed. RT, 1997, p. 1395.
} 
à legitimação subordinada. Para referidos autores, a legitimação autônoma significaria que basta a presença do legitimado extraordinário para tutela do direito violado ou ameaçado, independentemente de autorização ou participação do legitimado ordinário. Já no caso de legitimação subordinada, seria fundamental a presença do titular do direito material na demanda para legitimar a participação do legitimado extraordinário. ${ }^{52}$

Entende-se que a substituição processual é coerente com o sistema atualmente vigente e que ela se coaduna com as ideias postas pelos doutrinadores acerca da legitimação ordinária e legitimação autônoma. Nesse passo, compartilha-se do entendimento de Antônio Gidi, no sentido de não verificar “diferença ontológica” entre as demandas coletivas que buscam a defesa de direitos difusos ou coletivos e aquelas que pretendem tutelar o direito individual homogêneo, apesar de referido autor defender especificamente a legitimação autônoma. ${ }^{53}$

Importante mencionar, ainda, a definição específica dada pela doutrina para o caso das ações coletivas, e especialmente para fins desse trabalho, para o mandado de segurança coletivo, que estabelece a classificação da legitimação concorrente e disjuntiva.

A legitimação concorrente constitui hipótese em que o legitimado ordinário está autorizado a concorrer com o legitimado extraordinário para fins de tutela judicial do bem jurídico violado, sem que se suscite litispendência ou qualquer impeditivo ao legitimado ordinário, titular do direito.

Por outro lado, tem-se a legitimação exclusiva quando somente o legitimado extraordinário poderá atuar em juízo, por meio da demanda coletiva, nos termos definidos pela legislação, sendo vetado ao legitimado ordinário ingressar com medida concorrente. Nesse passo, o legitimado ordinário poderá tão somente habilitar-se como assistente na ação coletiva.

A legitimação concorrente pode ser classificada como disjuntiva ou conjunta. A disjuntiva refere-se à hipótese em que os diversos legitimados podem atuar em juízo

\footnotetext{
${ }^{52}$ CALMON DE PASSOS, José Joaquim. Mandado de Segurança Coletivo, Mandado de Injunção e Habeas Data - Constituição e Processo, Rio de Janeiro: Forense, 1989, p. 32.

${ }^{53}$ GIDI, Antonio. Coisa julgada e litispendência em ações coletivas. São Paulo: Saraiva, 1995, pp. 41 e 43.
} 
conjunta ou isoladamente, ou seja, qualquer legitimado pode atuar independentemente da autorização ou presença dos demais.

A legitimação conjunta é aquela em que, apesar de haver mais de um legitimado, todos devem atuar em conjunto, formando litisconsórcio necessário.

Sobre o tema, ensina Rodolfo de Camargo Mancuso ${ }^{54}$ que:

\begin{abstract}
A legitimação ativa na segurança coletiva é do tipo concorrente e disjuntiva, para usarmos expressão consagrada por José Carlos Barbosa Moreira. Isso significa que: 1) impetrada a segurança coletiva, v.g., pelo Sindicato dos Médicos, em princípio não se poderá descartar que a Associação Médica Brasileira impetrasse outro com o mesmo pedido; todavia, pela conexão quanto ao objeto (CPC, art. 103), ambas seriam reunidas para julgamento conjunto, até para se evitar o risco de decisões coletivas contraditórias; 2) se a segunda impetração for de um médico, individualmente, entendemos que darse-á o fenômeno da continência (CPC, art. 105) e a segurança individual será apensada à coletiva, para julgamento conjunto; 3) prosseguindo no exemplo, caso um médico pretenda intervir na segurança coletiva poderá fazê-lo litisconsorciando-se ao polo passivo, já que para o ativo não terá legitimação.
\end{abstract}

Sobre a questão da legitimação concorrente e disjuntiva é relevante ressalvarmos que a atuação de diversos legitimados pode trazer situações inconvenientes, caso não haja um efetivo controle e fiscalização do "legitimado adequado", tema que será abordado em capítulo específico deste trabalho. A entidade legitimada deve possuir condições técnicas de defesa efetiva do interesse em jogo, para promover a adequada tutela do direito a ser protegido. Desta forma, a legitimação concorrente dos titulares deve ser avaliada com cautela, de forma a preservar a adequada tutela do direito, assim como ocorre no caso das class actions do direito norte americano.

\footnotetext{
${ }^{54}$ MANCUSO, Rodolfo de Camargo. Uma análise crítica comparativa entre os objetos e legitimações ativas nas ações vocacionadas à tutela dos interesses metaindividuais: mandado de segurança coletivo, ação civil pública, ações do código de defesa do consumidor e ação popular, Justitia, v. 160. São Paulo: Órgão Oficial do Ministério Público do Estado de São Paulo, 1992, p. 193-194.
} 
No caso específico do mandado de segurança coletivo, parece que a melhor posição é aquela que postula pela legitimação extraordinária (por substituição processual) disjuntiva e concorrente, sendo plenamente possível o ajuizamento da demanda de forma individualizada pelo ente legitimado, mas também em litisconsórcio ativo de entidades. ${ }^{55}$

No entanto, apesar da possibilidade de se impetrar mandado de segurança coletivo e individual de forma concorrente, a concorrência entre dois mandados de segurança coletivos deve respeitar determinados requisitos, sob pena de se reconhecer a litispendência. A legitimação extraordinária legitima de forma idêntica as entidades e órgãos que possuam relação com o direito material violado e que possam defendê-lo da melhor maneira (pertinência temática e representação adequada). Por conta disso, há entendimento de que, se impetrados mandados de segurança coletivos com objetos idênticos em relação ao direito protegido e à abrangência dos sujeitos tutelados (titulares do direito material), deverá ser reconhecida a litispendência. Se a abrangência do objeto ou dos tutelados for menor ou maior, serão reconhecidas hipóteses de continência ou conexão, conforme o caso concreto. ${ }^{56}$

A litispendência, portanto, deve considerar os substituídos e não os substitutos.

Por fim importante consignar a relevante distinção entre substituição e representação. $\mathrm{O}$ art. $5^{\circ}$, XXI da $\mathrm{CF}$ estabeleceu hipótese específica de representação das entidades associativas, desde que expressamente autorizadas para tal fim, "para representar seus filiados judicial ou extrajudicialmente".

Referida previsão legal dispõe especificamente sobre a representação processual. Nesta, a entidade atuará em nome do próprio representado e mediante autorização deste.

\footnotetext{
${ }^{55}$ CALMON DE PASSOS, José Joaquim. Mandado de Segurança Coletivo, Mandado de Injunção e Habeas Data - Constituição e Processo, Rio de Janeiro: Forense, 1989, p. 31.

${ }^{56}$ LIMA, Sebastião de Oliveira. Mandado de Segurança Coletivo e Seus Principais Problemas. Revista Trimestral de Direito Público, no 3, São Paulo: Malheiros, 1993, p. 139.
} 
A autorização, no caso de interesse que envolva mais de uma pessoa, poderá ser realizada por meio de assembleia, sendo que apenas aqueles que concordarem com a representação, terão seu direito protegido em juízo.

A representação é ampla e, nesse passo, permite ao representante atuar em diversas esferas, inclusive para impetração de mandado de segurança individual.

Respeitadas as opiniões em contrário, a representação deve se ater ao objeto institucional da entidade. Nesse passo, o representante deve possuir liame subjetivo (no seu objeto social) em relação ao representado e ao direito a ser tutelado, ou seja, o interesse defendido deve possuir nexo com as finalidades da entidade. Não parece razoável que uma associação de defesa de consumidores busque tutelar em juízo, por meio de representação, o interesse religioso de um de seus membros.

Já a substituição processual (espécie do gênero legitimação extraordinária) foi explicitamente estabelecida, para fins do mandado de segurança coletivo, em sede do art. $5^{\circ}$, LXX, da CF. O substituto processual, diferentemente do representante, atua em nome próprio, na defesa do interesse material violado (do substituído), sem necessidade de autorização deste.

Exatamente nesse sentido o entendimento de Calmon de Passos, que assevera não apenas a forma de atuação do legitimado em sede de substituição processual, como aduz a necessidade de se reconhecer "um nexo que correlacione o interesse (jurídico) da entidade com o interesse (jurídico) do membro ou associado. ${ }^{57}$

Sobre o tema, o Ministro Marco Aurélio, do Supremo Tribunal Federal, asseverou que o art. $5^{\circ}$, XXI, da Constituição Federal, encerra justamente a hipótese de representação processual. Tratar-se-ia de instituto diverso da substituição processual, bastando, para a legitimidade da associação, a autorização dos associados. Veja-se parte da fundamentação de seu voto, proferido como relator no julgamento do Recurso em Mandado de Segurança (RMS) nº. 21.514/DF, em 27/04/1993, pela Segunda Turma do STF:

\footnotetext{
${ }^{57}$ CALMON DE PASSOS, José Joaquim. Mandado de Segurança Coletivo, Mandado de Injunção e Habeas Data - Constituição e Processo, Rio de Janeiro: Forense, 1989, p. 12-13.
} 
Com a Constituição Federal de 1988, buscaram-se as almejadas economia e celeridade processuais, procurando-se evitar a multiplicação de mandados de seguranças impetrados, isoladamente, pelos titulares de direito subjetivo que se mostrasse comum a uma certa coletividade, e a diversificação de decisões. Ao lado do tradicional mandado de segurança - inciso LXIX - previu-se o coletivo, definindo-se, no texto constitucional, os legitimados a impetrá-lo - inciso LXX, também do rol das garantias constitucionais. A conjugação deste dispositivo com o que se contém no inciso XXI do mesmo artigo não se mostra merecedora de agasalho. Os institutos neles contemplados são diversos. $\underline{\mathbf{O} \text { inciso XXI encerra } \mathbf{a}}$ representação em juízo, pressupondo a autorizacão dos filiados da entidade associativa. No preceito alude-se, expressamente, como necessária, a competente autorizacãão. Havendo esta, pouco importam as características do direito em questão. Vale dizer: inexigível é que entre este e a entidade associativa haja um elo. $\underline{\text { Mesmo que se trate de controvérsia totalmente estranha aos fins }}$ sociais, cabe, uma vez configurada a representação mediante ato de vontade do filiado, a atuacão da entidade e esta ocorrerá não no campo da substituicão processual, mas da simples representação. (grifou-se)

No mesmo sentido o entendimento da ministra Eliana Calmon do Superior Tribunal de Justiça:

PROCESSUAL CIVIL - RECURSO ORDINÁRIO EM MANDADO DE SEGURANÇA COLETIVO - DEFESA DE INTERESSE INDIVIDUAL - REPRESENTAÇÃO - NECESSIDADE DE AUTORIZAÇÃO EXPRESSA DO TITULAR DO DIREITO LEGITIMIDADE AD CAUSAM. 1. A Constituição Federal admite a atuação judicial da entidade associativa na defesa dos interesses de seus membros (art. $5^{\circ}$, incisos XXI e LXX). 2. Deve a associação, na hipótese de impetração de mandado de segurança coletivo, comprovar sua constituição segundo as exigências legais e funcionamento de pelo 
menos um ano. $\underline{\text { 3. Para a proteção, mediante ação individual, dos }}$ direitos individuais do associado, age a associacão em regime de representacão, e não na forma de substituicão processual, devendo, por isso, munir-se de autorizacão expressa do titular do direito defendido. 4. Hipótese de ajuizamento de mandado de segurança individual, mas sem autorização expressa do associado. 5. Ilegitimidade ad causam. 6. Processo extinto sem julgamento do mérito. Prejudicado o exame do recurso ordinário. (grifou-se)

Trecho do voto

Do texto constitucional, visualiza-se que, a par da atuação em prol dos associados, deve a associação, na hipótese de impetração de mandado de segurança coletivo, comprovar sua constituição segundo as exigências legais e funcionamento de pelo menos um ano; nos demais tipos de ações, ainda conforme a mesma norma, impõe-se a demonstração de autorização expressa, a qual, a depender do instrumento utilizado, pode ser estabelecida na letra da lei.

Distinguem-se, portanto, duas situacões distintas: uma verificada quando a associacão, para ver admitida sua atuacão em juízo - ou reconhecida a sua legitimidade - , depende de autorização expressa para tanto; e outra quando tal medida não lhe é exigida. Nessa última hipótese, enquadram-se o mandado de segurança coletivo e as ações coletivas, pois, nesses casos, a autorização exigida emana, respectivamente, da Constituição e das leis que disciplinam aquelas ações. $\mathrm{Na}$ outra espécie, encaixam-se as ações individuais ajuizadas na defesa dos direitos individuais dos associados, circunstância em que a autorização reclamada deve provir da anuência dos próprios associados. (grifou-se)

Esses eventos, na seara processual, atendem à determinação de que "ninguém poderá pleitear, em nome próprio, direito alheio, salvo quando autorizado por lei" (art. $6^{\circ}$ do CPC). No caso do mandado de segurança coletivo e das ações coletivas, como se disse, existe 
permissão para a atuação da associação em nome próprio, mas na defesa de direito alheio (o dos associados): nessa hipótese, tem-se o fenômeno da substituição processual, espécie de legitimação extraordinária. Já em relacãa às acões individuais, inexiste autorizacão legal para que a entidade associativa ajuíze, em seu próprio nome, acão favorável ao interesse de seus membros: nessa situação, deve a associacão atuar em nome do associado, em regime de representação. (grifou-se)

Essa distinção, a propósito, já foi realizada pelo Supremo Tribunal Federal no julgamento do MS 23.769-4BA, de relatoria da Min. Ellen Gracie, quando se disse que:

A medida utilizada pela Associação Nacional dos Procuradores do Trabalho - mandado de segurança coletivo - encontra respaldo no inciso LXX do art. $5^{\circ}$ da Constituição, que dá legitimação às associações para defender interesses dos seus associados. Não se trata, no caso, da representação de que cuida o inciso XXI, mas de hipótese de substituição processual, em que a associação, em nome próprio, defende direitos e interesses pertencentes aos seus associados. (...)

A entidade impetrante, em cumprimento às suas finalidades institucionais e em defesa de um interesse afeto a todos os seus associados (...), tem no caso legitimação direta, não intermediária para agir, na dicção de Sérgio Ferraz ("Mandado de Segurança (Individual e Coletivo) Aspectos Polêmicos, Malheiros, $3^{\text {a }}$ ed., pág. 43).

(STJ. RMS 22552/DF. Segunda Turma, Relatora Ministra Eliana Calmon, julgado em 19/04/2007, publicado em 30/04/2007).

Nota-se, pois, a clara distinção entre os conceitos de substituição processual e representação, sendo que o segundo não deve ser utilizado para fins de demandas coletivas, mas apenas individuais, exigindo, inclusive, a autorização do representado para atuação em juízo, diferentemente do que ocorre na substituição. 


\section{Representação Adequada}

A representação adequada (adequacy of representation) é relevante instituto do processo coletivo, apresentando-se como elemento agregador de segurança à relação processual, integrando o escopo da legitimação da demanda.

Referido instituto mostra-se importante principalmente nos sistemas em que há legitimação ativa da pessoa física, das associações e entidades de classe, bem como nos sistemas em que há extensão dos efeitos da coisa julgada aos terceiros que não integraram a lide. Isto porque, deve-se verificar a atuação de referidas pessoas e evitar que terceiros sejam atingidos por decisões produzidas em sede de ações mal conduzidas.

A representação adequada é estudada pelos doutrinadores, via de regra, quando se analisa a legitimação em demandas que envolvem interesses coletivos. Assim, quanto maior o rol de legitimados estabelecido pela legislação do país, mais importante a análise aprofundada do instituto.

Neste trabalho entende-se importante analisar individualmente a representação adequada, de forma a conceituá-la e, nessa linha, estabelecer suas importantes diretrizes para fins de identificação dos legitimados ativos para a impetração de mandado de segurança coletivo no direito brasileiro.

Apesar de aparentemente integrar o conceito de legitimidade, a representatividade adequada é defendida por alguns autores como conceito mais amplo em relação àquele, vez que "exige o reconhecimento pelo juiz de outros elementos no caso concreto de forma a garantir a satisfatória defesa da classe por seu membro",58

Nesse passo, a importância da análise correta do representante adequado se dá exatamente porque, via de regra, o autor da demanda é um terceiro, que se apresenta como representante dos verdadeiros interessados na proteção de seus direitos. Deve-se, pois,

${ }^{58}$ COSTA, Susana Henriques da. O Controle Judicial da representatividade adequada: uma análise dos sistemas norte-americano e brasileiro, in SALLES, Carlos Alberto de (coord.). As grandes transformações do processo civil brasileiro: homenagem ao Professor Kazuo Watanabe. São Paulo: Quartier Latin, 2009, p. 959. 
buscar garantir a adequada defesa de tais direitos, por aquele que melhor puder fazê-lo, ou seja, pelo "melhor representante".

\subsection{Procedimento da Ação Coletiva nos Estados Unidos e Representação Adequada}

Nos Estados Unidos, ao contrário do Brasil, inexiste rol de legitimados para tutela do interesse coletivo, razão pela qual o magistrado analisa em cada caso concreto, segundo condições e requisitos específicos (Rule 23 da lei processual americana), se a pessoa que ingressou com a demanda coletiva apresenta-se ou não como adequado representante do interesse defendido, devendo este integrar a classe cujo direito se busca a tutela ${ }^{59}$. Exatamente por conta de tal circunstância específica (ausência de rol de legitimados) o instituto se desenvolveu muito em referido país.

A representação adequada nos Estados Unidos é composta por dois elementos: a ausência de antagonismo ou conflito de interesses entre o representante e o grupo e a possibilidade de assegurar a vigorosa tutela dos interesses do grupo. Referidos elementos são verificados tanto em relação ao representante quanto ao eventual patrono. ${ }^{60}$

A mencionada Rule 23 da norma processual americana estabelece: (a) PréRequisitos para uma class action, que são apresentados em quatro subitens e (b) Requisitos para o regular prosseguimento da class action, que é subdividido em três subitens.

Como pré-requisitos para uma ação class action ser reconhecida como tal, tem-se que: (1) a quantidade de integrantes da classe seja tão grande que inviabilize o litisconsórcio de todos; (2) haja questões de direito ou de fato comuns à classe, (3) os pedidos ou defesas dos "representantes" reflitam o da classe; (4) o representante possa proteger de forma justa e adequada os interesses da classe.

\footnotetext{
59 GIDI, Antonio. A representação adequada nas ações coletivas brasileiras: uma proposta. Revista de Processo. vol. 108. São Paulo: Ed. RT, out.-dez. 2002. p. 63.

${ }^{60}$ Ibidem, p. 63
} 
Quanto ao primeiro requisito, não se trata de uma regra absoluta e extrema. Em verdade, a menção à "grande quantidade de integrantes da classe" tem como escopo evitar que haja prejuízo para a defesa dos direitos de referidos membros da classe, o que notoriamente pode ocorrer quando há diversos indivíduos atuando mutuamente e sem uma sincronia e unicidade de estratégia e qualidade técnica. ${ }^{61}$ Por isso, não é necessariamente o número de envolvidos que é levado em consideração para fins de assunção da demanda coletiva, mas se tal quantidade pode dificultar ou prejudicar sua defesa.

O segundo requisito está diretamente relacionado à tutela de direitos coletivos, referindo-se à existência de um elo fático ou de direito entre sujeitos que serão objeto de tutela na demanda, circunstância esta que também é fundamental para a promoção de demanda coletiva no Brasil. Ocorre que, nos Estados Unidos, permite-se ao magistrado, ainda na fase de reconhecimento (ou não) da lide como coletiva, delimitar os participantes ou a controvérsia, de forma a adequar a lide conforme os interesses e direitos envolvidos. Referida prerrogativa do magistrado é benéfica para o melhor aproveitamento da lide coletiva.

O terceiro requisito prossegue na mesma linha, definindo a necessidade de interesses comuns e não conflitantes como forma a viabilizar uma demanda coletiva adequada.

O último requisito reflete a concretização do preceito da representação adequada, mencionando expressamente que a atuação do representante deve ocorrer de maneira a efetivamente proteger os direitos e interesses envolvidos na causa.

No que concerne aos requisitos de prosseguimento da demanda como coletiva (b), tem-se que (1) o prosseguimento da demanda por um indivíduo criaria risco aos demais no que concerne a (i) decisões incompatíveis ou (ii) decisões que possam importar disposição de direitos aos membros da classe que não integraram a lide; (2) a parte contrária agiu ou recusou-se a agir em consenso com a classe, dando causa a medida cautelar ou declaratória em nome de toda a classe; (3) as questões de fato ou de direito dos membros da classe

\footnotetext{
${ }^{61}$ GIDI, Antonio. Class Action como instrumento de tutela coletiva dos direitos. As ações coletivas em uma perspectiva comparada. São Paulo: Ed. RT, 2007, p. 72.
} 
predominam sobre aquelas que afetam os membros individualmente e que a ação coletiva se mostra como o meio mais adequado para solução da controvérsia.

Nos Estados Unidos, portanto, há específica determinação legal para aceitação e prosseguimento da demanda coletiva, sendo que, a análise da representação adequada permeia referido processo, desde antes da aceitação da demanda como coletiva até o momento de sua execução.

Se em algum momento o "representante" deixa de possuir a característica de "adequado" ou se há alguma divergência de classes ou direitos, o juiz pode intervir e desconstituir o representante ou limitar a controvérsia ou o grupo. Tal atuação é dever do juiz, que atuará de ofício se verificar qualquer questão em sede inicial, instrutória, de julgamento ou até mesmo em recurso ou execução.

Assim, se o representante passa a ter interesses conflitantes com o do grupo ou se comete atos em desfavor deste, o grupo poderá ser desvinculado da sentença a ser proferida ou já proferida. Tal circunstância faz com que, muitas vezes, a parte adversa solicite a verificação da adequação do representante, para evitar futuros problemas de execução.

Nos Estados Unidos, portanto, a representação adequada é instituto de extrema relevância, vez que somente no caso concreto o magistrado estabelece o representante adequado, apesar de já possuir parâmetros para tanto.

\subsection{Representação Adequada no Brasil}

Como visto, o estudo do instituto da representação adequada teve origem nas class actions norte-americanas. No Brasil, o instituto em análise não encontrava grande aplicação, principalmente se considerado o fato de que a legitimação definida pelo sistema pátrio é ope legis. Ocorre que sua importância tem crescido nos últimos anos, principalmente em vista da intervenção dos doutrinadores. 
Boa parte da doutrina defendia a inexistência de controle judicial em relação à adequação do representante. Em sendo o proponente da demanda pessoa legitimada a ajuizar a ação coletiva segundo a legislação pátria, pouco âmbito de atuação havia ao magistrado para rejeitar referido "representante", tampouco para extinguir o feito.

Recentemente passou-se a verificar o grande problema gerado pela representação inadequada de determinados interesses, que implicava em prejuízo direto aos indivíduos que deveriam ser representados.

Por esta razão, a doutrina buscou desenvolver o instituto no país, de forma a tornar mais ampla a sua aceitação e análise, tanto no que concerne à verificação da legitimidade do "representante", como até mesmo pela verificação de tal condição em momento antecedente à propositura da demanda coletiva.

Referido instituto tomou um forte liame subjetivo. A análise da "adequação" passou a ser prévia, apesar de seu reconhecimento efetivo se dar por decisão do magistrado no caso concreto, com base no rol de legitimados, quando do ajuizamento da demanda.

Sua definição foi relacionada à qualidade do representante, pautada na possibilidade deste proporcionar uma defesa eficiente aos representados.

Nada obstante, inexiste até o momento a previsão expressa em textos legais da representação adequada como requisito específico da ação coletiva.

A professora Ada Pellegrini Grinover, propõe que a adequada representatividade deva ser analisada com base em três requisitos fundamentais: (i) credibilidade, capacidade e experiência do legitimado; (ii) seu histórico na proteção judicial e extrajudicial dos interesses ou direitos difusos e coletivos; (iii) sua conduta em eventuais processos coletivos em que tenha atuado.

No Brasil, apesar de haver um rol legalmente estabelecido de legitimados, o estudo da representação adequada, em conjunto com teorias doutrinárias de legitimação da ação, 
tem permitido a atuação de outros entes que não aqueles expressamente previstos na $\mathrm{CF}$ e na Lei 12.016/2009 (no caso específico do mandado de segurança coletivo).

Exatamente por conta da grande subjetividade do instituto, a verificação do representante adequado pode levar a diferentes opiniões e interpretações conforme a situação concreta se apresente.

Importante mencionar que a representação adequada não está diretamente relacionada ao clássico conceito de representação do processo civil. O representante adequado deve se apresentar como um verdadeiro porta-voz dos representados.

No que concerne à natureza jurídica do instituto, esta foi apresentada de diferentes formas por diversos autores processualistas, sendo mencionada como: critério, requisito, aptidão, aspecto, qualidade, pressuposto e condição. ${ }^{62}$

O instituto, se analisado dentro do escopo do processo judicial ajuizado, integraria a legitimidade e, como tal, seria uma condição da ação ou pressuposto processual.

Porém, se observada de forma singular a representação adequada pode ser verificada antes mesmo do ajuizamento da demanda. $\mathrm{O}$ representante adequado o é antes mesmo de ingressar com a petição inicial. Em determinadas situações, poderia haver mais de um legitimado ativo, no entanto, para que se identifique qual é o representante adequado deve ser feita uma análise prévia, que será apenas confirmada em juízo pelo magistrado, e permitirá o regular prosseguimento da lide ou determinará sua extinção de plano.

Nesse sentido se mostra razoável o entendimento de Cassio Scarpinella Bueno, de que, apesar da ausência de expressa previsão de tal requisito, a representação adequada se apresentaria como questão prejudicial da ação. ${ }^{63}$ Seria, portanto, critério que permite aferir

\footnotetext{
${ }^{62}$ V. PASCHOAL, Maximiliam Fierro. A representatividade adequada na Ação Coletiva Brasileira (Lei da Ação Civil Pública e Código de Defesa do Consumidor). Dissertação de Mestrado, São Paulo, Faculdade de Direito da USP, 2007, p. 106-109.

${ }^{63} \mathrm{O}$ autor defende que "a representatividade adequada é questão prejudicial para o processamento de uma demanda, é condição de prejudicialidade" - SCARPINELLA BUENO, Cassio. As class actions norteamericanas e as ações coletivas brasileiras: pontos para uma reflexão conjunta. Revista de processo, ano 21, n. 82, abr-jun 1996, p. 102.
} 
a legitimidade do autor da lide, que implica na rejeição de plano da lide no caso de seu não cumprimento.

Por outro lado, a representação adequada não é apenas critério de aferição da legitimidade. Esta se mostra como conceito singular que se complementa ao da legitimidade, podendo ser avaliado previamente à existência do processo, segundo a relação material existente entre o potencial autor da ação e as pessoas cujo direito se buscará tutelar em juízo, conjuntamente com a confiabilidade, acuidade e capacidade técnica do representante.

Nessa esteira, bastante plausível o entendimento de Flávia Fornaciari, que assevera ser a representatividade adequada "uma qualidade apresentada pelo representante que atuará em nome da sociedade ou do grupo na defesa de interesses de ordem coletiva, qualidade essa identificada como a possibilidade da defesa eficiente e tenaz dos interesses envolvidos, seja no âmbito social, administrativo ou judicial.",64

Referido entendimento converge com o de Álvaro Mirra, que aduz ser a representação adequada uma:

(...) especial qualidade que titulares do direito de agir devem apresentar, consistente na aptidão para a defesa escrupulosa e eficiente, na esfera judicial, dos interesses da sociedade, em perfeita sintonia com as expectativas da coletividade na matéria, mesmo diante de litígios complexos e difíceis, muitas vezes contra os detentores do poder econômico (grandes grupos econômicos) e do poder político (dos próprios governos). ${ }^{65}$

Nesse passo, o conceito do representante adequado não está necessariamente ligado ao processo, sendo que a defesa de determinados interesses coletivos (ambientais, consumeristas, de um grupo social ou classe) possuem potencialmente um representante adequado, que não necessariamente integra a classe ou grupo cujos direitos foram violados.

${ }^{64}$ FORNACIARI, Flávia Hellmeister Clito. Representatividade adequada nos processos coletivos. Tese de Doutorado, São Paulo, Faculdade de Direito da USP, 2010, p. 50.

${ }^{65}$ MIRRA, Álvaro Luiz Valery, Associações civis e a defesa dos interesses difusos em juízo: do direito vigente ao direito projetado, in GRINOVER, Ada Pellegrini e outros (coord.). Direito Processual Coletivo e anteprojeto de Código Brasileiro de Processos Coletivos. São Paulo: Ed. RT, 2007, p. 117. 
A partir do ingresso em juízo, tal condição será avaliada pelo magistrado, que verificará no caso concreto a adequação de tal representação, e se de fato o ente poderá propiciar a melhor defesa aos "representados".

No entanto, mesmo após o ajuizamento da demanda, muitas vezes o representante pode se mostrar incapaz de tutelar os interesses do grupo, conduzindo o processo de maneira desidiosa quer por incapacidade técnica, quer por perda de interesse no litígio.

Tal situação, porém, ainda não é tutelada pela legislação pátria e tem sido abordada por alguns doutrinadores ${ }^{66}$.

Entretanto verificam-se na norma processual vigente algumas limitações objetivas já postas, de forma a tentar propiciar uma representação adequada. Esta é a situação da exigência legal de que a associação seja legalmente constituída e esteja em funcionamento há pelo menos um ano. Tal determinação visa a evitar situações de exceção, em que associações sejam criadas apenas para ajuizar determinada demanda. O mesmo vale para os partidos políticos, que devem ter representação no Congresso, ou seja, que devem possuir alguma experiência política para pretender atuar na defesa de direitos coletivos em juízo.

A par das circunstâncias legalmente estatuídas supramencionadas, notoriamente que apenas esses requisitos objetivos não se mostram suficientes, por isso os doutrinadores pátrios têm defendido que o representante possua capacidade técnica, confiabilidade, seriedade, certa experiência e familiaridade com o interesse a ser tutelado, afinidade com o grupo cujo direito se pretenda defender, entre outros.

Em que pese tais importantes contribuições doutrinárias, muitas vezes têm-se limitado sua atuação ao reconhecimento da pertinência temática do objeto das entidades

\footnotetext{
${ }^{66}$ Gidi sugere que o controle da representação adequada seja feita pelo magistrado no início e no curso da lide: "Se o juiz detectar a eventual inadequação do representante, em qualquer momento do processo, deverá proporcionar prazo e oportunidade para que o autor inadequado seja substituído por outro, adequado. Caso contrário, o processo deve ser extinto sem julgamento do mérito. Se o juiz, inadvertidamente, atingir o mérito da causa, a sentença coletiva não fará coisa julgada material e a mesma ação coletiva poderá ser reproposta por qualquer legitimado." (GIDI, Antonio. A representação adequada nas ações coletivas brasileiras: uma proposta. Revista de Processo. vol. 108. São Paulo: Ed. RT, out.-dez. 2002. p. 63).
} 
em relação aos direitos e interesses defendidos em juízo, bem como aos respectivos "representados", como se verá a seguir.

\section{Pertinência Temática}

Apesar de alguns autores correlacionarem pertinência temática e "representatividade adequada", entendemos que existe distinção entre ambos os conceitos, referindo-se pertinência temática a um caráter secundário e menos amplo em relação à representação adequada.

A pertinência temática seria o vínculo entre o direito a ser tutelado e o objeto institucional do ente, ou seja, sua finalidade específica como órgão.

Como já visto nesse trabalho, os requisitos específicos de existência da ação são denominados "condições da ação". São eles: legitimidade, interesse processual e possibilidade jurídica do pedido (que poderia ser incorporada pelo interesse processual).

A análise de tais requisitos deve ser, via de regra, prévia ao mérito e a ausência de um destes implicará o proferimento de decisão extintiva do processo. Ocorre que, como visto, há grande interação entre as condições da ação, sendo que a pertinência temática possuiria maior ponto de conexão com o interesse processual.

No Brasil, considerada a circunstância de que legitimação para ação coletiva seria ope legis, a determinação do preenchimento de tal requisito decorreria da lei, sendo que, no que se refere ao interesse processual, as situações para sua verificação se dariam conforme o caso concreto.

A verificação atinente à correlação entre o direito material a ser tutelado, seu titular e a finalidade do órgão legitimado seriam pertinentes para fins de averiguação do interesse de agir do legitimado extraordinário, refletindo tal circunstância sobre a pertinência temática. Nada obstante, a constatação de tal requisito seria também fundamental para análise da legitimidade da entidade. 
Nesse sentido o entendimento de Luiz Manoel Gomes Jr., ao asseverar que "a pertinência temática possui uma maior correlação com o interesse processual do que com a legitimidade ad causam, apesar da dificuldade em efetuar uma separação precisa, já que analisada frente a uma determinada situação em concreto". ${ }^{67}$

A principal questão a ser avaliada na hipótese é se, diante da expressa previsão de legitimidade de alguns entes para a tutela coletiva e especialmente para a impetração de mandado de segurança coletivo, deve ser cumprido também o requisito da pertinência temática em relação a todos os legitimados.

Referida análise é feita de maneira mais aprofundada nos capítulos destinados especificamente a cada ente, no entanto, adiantamos neste momento parte da discussão e um breve resumo da situação atual.

“A dúvida que pode ser identificada neste ponto diz respeito à necessidade ou não de demonstração de interesse específico, ou da chamada pertinência temática, para a promoção da defesa de determinados interesses pelos legitimados". ${ }^{6}$

O Ministério Público possui legitimação ampla, legalmente prevista, razão pela qual a avaliação da "pertinência temática" em relação a ele também deve ser lata e relacionada a seu escopo de proteção dos interesses sociais e individuais indisponíveis.

Com relação às associações, deve haver coincidência entre seus fins institucionais e o interesse perquirido na demanda coletiva. O mesmo vale para os sindicatos, que somente poderiam defender questões afetas à categoria ou ao meio ambiente do trabalho. Para os órgãos da administração indireta, vale também a regra da necessária correlação do interesse protegido com sua finalidade institucional.

Já em relação aos partidos políticos, há grande divergência entre os autores. Há aqueles que defendem a legitimidade apenas em relação a filiados e interesses relacionados à finalidade do partido, o que exigiria o cumprimento do requisito da pertinência temática.

\footnotetext{
${ }^{67}$ GOMES JÚNIOR, Luiz Manoel. Curso de direito processual civil coletivo. Rio de Janeiro: Forense, 2005, p. 85.

${ }^{68}$ LEONEL, Ricardo de Barros. Manual do processo coletivo. São Paulo: Ed. RT, 2002, p. 163.
} 
Outros autores, entretanto, pugnam pela possibilidade do partido político defender questões de direito público, como: meio ambiente, patrimônio cultural e histórico, entre outros. Nessas hipóteses não seria necessário o cumprimento do requisito da pertinência temática.

Ante tais circunstâncias e respeitado o entendimento em contrário, a pertinência temática deve ser interpretada como requisito de admissibilidade de demanda coletiva, que necessitará ser cumprido por alguns dos legitimados legalmente estabelecidos. Ou seja, a mera previsão legal de legitimação não é condição suficiente e exclusiva para permitir a atuação de determinados entes na tutela de direitos coletivos, sendo que estes direitos devem estar correlacionados à finalidade institucional do órgão legitimado.

\section{O Mandado de Segurança Individual}

\subsection{Evolução histórica do instituto}

O mandado de segurança individual teve como origem a teoria brasileira do habeas corpus. Em sua primeira consagração legislativa ficou subordinado ao regime deste instituto, com vistas a proteger o indivíduo em relação a atos abusivos do Poder Público. ${ }^{69}$

Sua primeira normatização ocorreu na Constituição de 1934, em seu art. 113, inciso 33, com a seguinte previsão: "Dar-se-á mandado de segurança para a defesa de direito certo e incontestável ameaçado ou violado por ato manifestamente inconstitucional ou ilegal de qualquer autoridade", ${ }^{70}$

A Lei $\mathrm{n}^{\mathrm{o}}$ 191, de 16 de janeiro de 1936, estabeleceu os procedimentos para impetração, seu trâmite, julgamento e âmbito de atuação. ${ }^{71}$

Referida lei foi revogada com a edição do Código de Processo Civil de 1939, que regulou por inteiro a matéria em seus arts. 319 a 331.

\footnotetext{
${ }^{69}$ BOTELHO DE MESQUITA, José Ignacio. O Mandado de Segurança - Constribuição para o seu estudo. Revista dos Tribunais, v. 825, São Paulo: Ed. RT, 2004, p. 76.

${ }^{70}$ MOEMEZZO, Marta Casadei. Mandado de Segurança Coletivo: aspectos polêmicos. São Paulo: LTr, 2000, p. 21.

${ }^{71}$ OLIVEIRA, Francisco Antonio. Mandado de Segurança e Controle Jurisdicional. $2^{\mathrm{a}}$ ed. São Paulo: Ed. RT, 1996, pp. 24-25.
} 
A Constituição de 1937 retirou de seu texto a previsão do mandado de segurança, tendo sido o instituto retomado constitucionalmente em 1946, com o retorno da democracia no país. Foi nesta Carta Magna que se separou a utilização penal e cível do writ, passando a prever também que sua aplicação se daria para proteção de "direito líquido e certo" nos casos não amparados por habeas corpus. ${ }^{72}$

A evolução do instituto se deu conforme o desenvolvimento político do país e de garantia (ou privação) das suas liberdades individuais, principalmente entre os anos de 1930 a 1951.

No ano de 1951 foi editada a notoriamente conhecida Lei 1.533/51, que regulamentou o procedimento do mandado de segurança.

A Carta Magna de 1967 manteve a disposição relativa ao writ sem alterações.

A Constituição Federal de 1988 dispôs sobre o instituto no art. 5ª incisos LXIX e LXX, tendo trazido notável inovação ao estabelecer o mandado de segurança coletivo.

A definição do art. 5, LXIX, é de que "conceder-se-á mandado de segurança para proteger direito líquido e certo, não amparado por 'habeas-corpus' ou 'habeas-data', quando o responsável pela ilegalidade ou abuso de poder for autoridade pública ou agente de pessoa jurídica no exercício de atribuições do Poder Público".

Antes da promulgação da $\mathrm{CF} / 88$, os legitimados ativos para impetração de mandado de segurança eram as pessoas físicas e jurídicas por conta de atos que lhes atingisse diretamente, os órgãos públicos despersonalizados, mas dotados de capacidade processual e as universalidades reconhecidas por lei (condomínio, espólio) também possuíam legitimidade para o writ individual.

Conforme ensina Hely Lopes Meirelles, "o essencial para impetração é que o impetrante - pessoa física ou jurídica, órgão público ou universalidade legal - tenha 
prerrogativa ou direito próprio e individual a defender, e que esse direito se apresente líquido e certo ante o ato impugnado"73.

\subsection{Natureza Jurídica}

Muito se discute acerca da natureza jurídica do mandado de segurança. Apesar da posição dominante na doutrina pátria afirmar que o mandado de segurança é ação, os autores apontaram as mais diversas denominações para instituto, como causa, medida cautelar, interdito possessório, garantia/remédio constitucional. ${ }^{74}$

Segundo Pontes de Miranda, a "ação de mandado de segurança é tipicamente ação mandamental, como o é, no direito constitucional e no direito processual penal, a ação de habeas corpus". 75

Hely Lopes assevera que o mandado de segurança seria ação civil de rito sumário especial, destinado a afastar ofensa a direito subjetivo próprio. ${ }^{76}$

Em linha semelhante, Seabra Fagundes aduz que o mandado de segurança seria "ação civil, de rito sumaríssimo, destinada a suscitar o controle jurisdicional sobre ato de qualquer autoridade que, por sua ilegalidade ou abuso de poder, viole ou ameace direito individual". 77

Moacyr Amaral Santos defende que "o mandado de segurança tem a natureza de ação de conhecimento, nas suas várias modalidades meramente declaratórias, constitutivas ou condenatórias" conforme o efeito da providência suscitada. ${ }^{78}$

\footnotetext{
${ }^{73}$ MEIRELLES, Hely Lopes. Mandado de Segurança, ação popular e ação civil pública, $11^{\mathrm{a}}$ ed., São Paulo: Ed. RT, 1987, pp. 4-5.

${ }^{74}$ CRETELLA JR., José. Do mandado de Segurança Coletivo. Rio de Janeiro: Forense, 1999, pp. 18-25.

${ }^{75}$ PONTES DE MIRANDA. Comentários ao Código de Processo Civil, v. 4, 2a ed., Rio de Janeiro: Forense, 1959, p. 431.

${ }^{76}$ Ibidem, p. 6.

${ }^{77}$ FAGUNDES, Miguel Seabra. O Controle dos atos administrativos do Poder Judiciário, $5^{\text {a }}$ ed., Rio de Janeiro: Forense, 1979, p. 259.

${ }^{78}$ SANTOS, Moacyr Amaral. Natureza Jurídica do Mandado de Segurança. Revista de Direito Privado, ${ }^{\circ}$ 17, p. 16.
} 
Botelho de Mesquita defende que o mandado de segurança seria ato de intervenção, fundado em princípio hierárquico que submete ao controle do judiciário todos os atos estatais. $^{79}$

Importante considerar que a doutrina nacional majoritária classifica o mandado de segurança como ação, havendo divergência quanto à espécie de ação, sendo que o estudo de sua natureza jurídica se dá não apenas por didática, mas para definição do regime jurídico do instituto.

\subsection{Requisitos}

O art. 5 $5^{\circ}$ LXIX da CF e o art. $1^{\circ}$ da Lei 12.016/2009 preveem a possibilidade de mandado para proteger "direito líquido e certo", não amparado por "habeas corpus" ou "habeas data", contra atos cometidos ilegalmente ou com abuso de poder.

No que concerne ao ato violador do direito, enquanto a Carta Magna trata de atos de "autoridade pública ou agente de pessoa jurídica no exercício de atribuições do Poder Público", a nova lei do mandado de segurança trata de atos "de autoridade, seja de que categoria for e sejam quais forem as funções que exerça”.

Vê-se, pois, que o requisito essencial é a tutela de direito líquido e certo, considerado este como aquele que apresenta alto grau de probabilidade e que pode ser verificado de imediato, pelos documentos apresentados, sem necessidade de dilação probatória.

Nesse ponto, outro requisito fundamental, é a prova pré-constituída da certeza do direito e da ameaça ou lesão a este.

Por fim, tem-se a exigência da ilegalidade do ato ou sua prática mediante abuso de poder. Tal disposição significa a ocorrência de atos comissivos ou omissivos praticados de forma arbitrária, desproporcional ou com desvio de finalidade. Especificamente sobre a

\footnotetext{
${ }^{79}$ BOTELHO DE MESQUITA, José Ignacio. O Mandado de Segurança - Contribuição para o seu estudo. Revista dos Tribunais, v. 825, São Paulo: Ed. RT, 2004, p. 76.
} 
legalidade, notoriamente significa a existência de norma que impeça a prática do ato ou determine que sua prática ocorra de forma diversa.

O prazo para impetração permaneceu na Lei 12.016/2009 de 120 (cento e vinte) dias "contados da ciência, pelo interessado, do ato impugnado" (art. 23).

No que concerne especificamente à autoridade coatora, verifica-se que na Lei 12.016/2009 houve certa flexibilização, abrangendo aquele que tenha praticado o ato impugnado ou aquele que tenha emanado ordem para sua prática, ou seja, tanto o servidor, quanto o agente público. Pela nova redação, portanto, a impetração é cabível contra o executor do ato (independentemente da execução decorrer de cumprimento de ordem de superior), mas também em face de seu superior que tenha emanado a ordem. Tal sistema assemelha-se ao da lei que regulamentou os processos administrativos federais (Lei $9.784 / 99^{80}$ ).

Referida alteração legal tornou o processo mais célere, minimizando erros na indicação da autoridade coatora.

A nova Lei 12.019/2009 sedimentou alguns avanços previstos pela doutrina e jurisprudência. No entanto, trouxe também alguns retrocessos, principalmente no que concerne à tutela do mandado de segurança coletivo, seus legitimados e direitos tutelados, como se verá oportunamente neste trabalho.

\section{A tutela dos interesses coletivos}

\subsection{Evolução histórica do Instituto}

Inicialmente, mostra-se importante traçar um breve histórico sobre a evolução do processo brasileiro e o tratamento à defesa dos interesses coletivos ao longo dos anos.

\footnotetext{
${ }^{80}$ Art. $1^{\mathrm{o}}(\ldots) \S 2^{\mathrm{o}}$ Para os fins desta Lei, consideram-se:

III - autoridade - o servidor ou agente público dotado de poder de decisão.
} 
A doutrina dominante assevera a origem da tutela coletiva no bill of peace, do século XVII, que representava uma "autorização para processamento de uma ação individual", que "era concedida quando o autor requeria que o provimento englobasse os direitos de todos que estivessem envolvidos no litígio, tratando da questão de maneira uniforme, evitando a multiplicação de processos" ${ }^{\$ 1}$. À época, tal tutela visava, por economia, a apresentar diversos interesses comuns dos indivíduos da comunidade em um só processo.

Com a evolução da sociedade, fim do feudalismo e, principalmente a partir da Revolução Francesa, passou-se a valorizar de forma proeminente o indivíduo, dando-se ênfase ao "sujeito de direitos" em detrimento do coletivo. Houve, pois, um desestímulo às ações coletivas.

Contudo, a partir da Revolução Industrial e do sindicalismo iniciou-se novamente a superação ao individualismo, passando a predominar a ideia de "pessoa" (inserida em uma sociedade com interesses mútuos e comuns) em detrimento à ideia de indivíduo. Tal pensamento influenciou também o âmbito processual, como forma de solucionar as complexas e numerosas lides que passaram a surgir.

O Brasil sofreu influência direta de tal movimento. Apesar de algumas nuances na Lei 4.717/65 (Lei de Ação Popular), a primeira previsão expressa de tutela dos interesses coletivos ocorreu apenas na Lei Complementar $n^{\circ}$ 40/81 (Lei Orgânica do Ministério Público).

O Brasil foi o primeiro país ibero-americano a iniciar o pensamento coletivo e a desenvolver mecanismo de defesa desses direitos.

Referida normatização, em seus artigos $4^{\circ}$, inciso III; 10 , inciso VIII e $24^{82}$, inciso VI, previa a promoção da ação civil pública como atribuição específica do Ministério

${ }^{81}$ LEAL, Márcio Mafra. Ações Coletivas: História, Teoria e Prática. Sérgio Antonio Fabris Editor, Porto Alegre, 1998, pp 21-23.

${ }^{82}$ Art. $4^{\circ}$ - São funções institucionais do Ministério Público:

(...) III - promover a ação civil pública, nos termos da lei. 
Público, com vistas a tutelar a "proteção do patrimônio público e social, do meio ambiente, do consumidor, do contribuinte, dos grupos socialmente discriminados e de qualquer outro interesse difuso e coletivo, atuando como fiscal da lei sempre que a ação não for proposta pelo Ministério Público".

Nada obstante tal previsão, a proteção efetiva dos interesses coletivos passou a ter expressão com a promulgação da Lei 7.347/85 (Lei da ação civil pública), que regulou especificamente referida ação de tutela coletiva e aumentou o rol dos legitimados.

A ação civil pública, nos termos da citada legislação, se prestaria à proteção relativa aos danos causados ao meio ambiente, ao consumidor, a bens e direitos de valor artístico, estético, histórico, turístico e paisagístico (e "qualquer outro interesse difuso ou coletivo”), bem como infrações à ordem econômica e urbanística.

A Constituição Federal de 1988 também tratou da matéria em seu art. 129, inciso III $^{83}$, ao estabelecer a ação civil pública como função precípua do Ministério Público, bem como em seu art. $5^{\circ}$, inciso LXXIII ${ }^{84}$, ao tratar da ação popular.

No que concerne especificamente ao mandado de segurança coletivo, este foi normatizado pela primeira vez no país exatamente na Carta Magna de 1988.

Art. 10 - Incumbe ao Procurador-Geral de Justiça, especialmente, além de outras atribuições que lhe sejam conferidas por Lei ou que forem inerentes a seu cargo:

(...)

VIII - Promover o inquérito civil e a ação civil pública para proteção do meio ambiente, dos direitos do consumidor, do patrimônio público e social e de outros interesses difusos e coletivos, atuando como fiscal da lei sempre que a ação não for proposta pelo Ministério Público; (inciso revogado pela Lei Complementar $\left.n^{\circ} 92 / 2000\right)$

Art. 24 - São atribuições dos Membros do Ministério Público:

(...)

VI - promover o inquérito civil e a ação civil pública para proteção do patrimônio público e social, do meio ambiente, do consumidor, do contribuinte, dos grupos socialmente discriminados e de qualquer outro interesse difuso e coletivo, atuando como fiscal da lei sempre que a ação não for proposta pelo Ministério Público.

${ }^{83}$ Art. 129. São funções institucionais do Ministério Público:

(...) III - promover o inquérito civil e a ação civil pública, para a proteção do patrimônio público e social, do meio ambiente e de outros interesses difusos e coletivos;

${ }^{84}$ LXXIII - qualquer cidadão é parte legítima para propor ação popular que vise a anular ato lesivo ao patrimônio público ou de entidade de que o Estado participe, à moralidade administrativa, ao meio ambiente e ao patrimônio histórico e cultural, ficando o autor, salvo comprovada má-fé, isento de custas judiciais e do ônus da sucumbência; 
Embora existente a figura do mandado de segurança individual desde a Constituição de 1934, tendo sido suprimida em apenas uma situação (na Carta de 1937), foi apenas na Carta de 1988 que o instituto coletivo tomou forma.

A CF/88 ampliou a figura do mandado de segurança individual, para contemplar também a tutela coletiva, conforme estabelecido no art. $5^{\circ}$, incisos LXIX e LXX ${ }^{85}$, sendo que o inciso LXX trata especificamente da legitimação.

A Constituição Federal, assim, não estabeleceu uma nova figura alheio ao writ individual, mas sim estabeleceu técnica de substituição processual que permitiu novas hipóteses de legitimação da causa. ${ }^{86}$

Sobre o tema, José Carlos Barbosa Moreira definiu que são "figuras processuais específicas de ações coletivas: o mandado de segurança coletivo, a ação popular e a ação civil pública" ${ }^{87}$.

A partir da Lei 7.347/85 e da previsão constitucional sobre a matéria, diversas outras normas surgiram para a tutela dos interesses coletivos lato sensu. Dentre estas, merecem destaque: Lei 7.853/89 (Defesa dos Interesses das Pessoas Portadoras de Deficiência); Lei 8.069/90 (Estatuto da Criança e do Adolescente); Lei 8.078/90 (Código de Defesa do Consumidor); Lei 8.429/92 (Improbidade Administrativa); Lei 8.884/94 (Defesa da Ordem Econômica); Lei 8.625/93 (Lei Orgânica do Ministério Público); Lei 10.741/03 (Estatuto do Idoso); e disposições constitucionais e infraconstitucionais concernentes ao Mandado de Segurança Coletivo (art. 5 , inciso LXX, da CF/88 e Lei 12.016/09).

${ }^{85}$ LXIX - conceder-se-á mandado de segurança para proteger direito líquido e certo, não amparado por "habeas-corpus" ou "habeas-data", quando o responsável pela ilegalidade ou abuso de poder for autoridade pública ou agente de pessoa jurídica no exercício de atribuições do Poder Público; LXX - o mandado de segurança coletivo pode ser impetrado por:

a) partido político com representação no Congresso Nacional;

b) organização sindical, entidade de classe ou associação legalmente constituída e em funcionamento há pelo menos um ano, em defesa dos interesses de seus membros ou associados;

${ }^{86}$ BUENO, Cassio Scarpinella, Mandado de segurança. São Paulo: Saraiva, 2002, p. 28-29.

87 BARBOSA MOREIRA, José Carlos. Ações Coletivas na Constituição Federal de 1988. Revista de Processo nº 61. São Paulo: Editora Revista dos Tribunais, pp. 189-190. 
Dentre as disposições legais referidas supra, a de maior destaque, relativamente à tutela dos interesses coletivos, é o Código de Defesa do Consumidor. Este não apenas concedeu uma proteção mais ampla às lides coletivas, como definiu conceitos de extrema importância para o desenvolvimento do instituto. Como se verá neste trabalho, foi o CDC que conceituou os direitos e interesses difusos, coletivos stricto sensu e individuais homogêneos, bem como definiu proteção específica a cada um destes.

No que diz respeito ao mandado de segurança coletivo, sua regulamentação específica ocorreu com a edição da Lei 12.016/2009, que tratou da matéria em seu art. 21. Verifica-se que referida regulamentação, ao invés de ampliar a abrangência do instituto prevista na CF, o limitou, dando causa a uma série de discussões sobre os legitimados ativos para atuação em juízo, bem como sobre o limite do campo de atuação destes.

Como alguns exemplos desta situação, temos a limitação ao âmbito de atuação dos partidos políticos, trazida pelo art. 21, caput da Lei, em relação à previsão constitucional, bem como a ausência de previsão da tutela de direitos difusos no art. 21, parágrafo único da Lei.

No presente trabalho busca-se exatamente traçar referidos problemas e propor soluções à questão da legitimação ativa e interesses tuteláveis em juízo pelos legitimados.

\subsection{Os direitos difusos, coletivos e individuais homogêneos}

Nada obstante a existência de normatização que tratava pontualmente da tutela dos interesses coletivos em situações específicas, a grande evolução sobre a matéria ocorreu a partir dos conceitos trazidos pelo Código de Defesa do Consumidor que, a nosso ver, deve ser utilizado de forma a complementar a regulamentação do mandado coletivo trazida pela Constituição Federal e pela Lei 12.016/2009.

Referido diploma, em seu art. 81, parágrafo único, inciso $\mathrm{I}^{88}$ definiu a tutela dos interesses difusos, definindo-os como aqueles interesses transindividuais que decorrem de

\footnotetext{
${ }^{88}$ Art. 81. A defesa dos interesses e direitos dos consumidores e das vítimas poderá ser exercida em juízo individualmente, ou a título coletivo.
} 
uma situação de fato que afeta indivíduos indeterminados. Nesse passo, o objeto é indivisível e os sujeitos são indeterminados, estando estes ligados por um fato específico.

Para Rodolfo de Camargo Mancuso os direitos difusos:

São interesses metaindividuais que, não tendo atingido o grau de agregação e organização necessário à sua afetação institucional junto a certas entidades ou órgãos representativos dos interesses já socialmente definidos, restam em estado fluido, dispersos pela sociedade civil como um todo (por exemplo, o interesse à pureza do ar atmosférico), podendo, por vezes, concernir a certas coletividades de conteúdo numérico indefinido (por exemplo, os consumidores). ${ }^{89}$

Os principais exemplos relacionados aos direitos difusos são referentes a questões consumeristas e ambientais.

Sobre o tema, o ilustre jurista Hugo Nigro Mazzili ${ }^{90}$ traz lições relativamente ao elo fático que une os indivíduos atingidos e define a situação como caracterizadora de dano a direito difuso, aduzindo exemplos esclarecedores sobre tais situações, como a propaganda enganosa. Veja-se:

Advirta-se, porém, que embora o CDC se refira a ser uma situação
fática o elo comum entre os lesados que compartilhem o mesmo
interesse difuso, é evidente que essa relação fática também se
subordina a uma relação jurídica (como, de resto, ocorre com
quaisquer relações fáticas e jurídicas); entretanto, no caso dos
interesses difusos, a lesão ao grupo não decorrerá diretamente da
relação jurídica em si, mas sim da situação fática resultante. Assim, p.
ex., um dano ambiental que ocorra numa região envolve tanto uma

Parágrafo único. A defesa coletiva será exercida quando se tratar de:

I - interesses ou direitos difusos, assim entendidos, para efeitos deste código, os transindividuais, de natureza indivisível, de que sejam titulares pessoas indeterminadas e ligadas por circunstâncias de fato;

${ }^{89}$ MANCUSO, Rodolfo de Camargo. Interesses difusos - conceito e legitimação para agir. São Paulo: Ed. RT, 1988, p. 105.

${ }^{90}$ MAZZILLI, Hugo Nigro. A defesa dos interesses difusos em juízo: meio ambiente, consumidor e patrimônio cultural, patrimônio público e outros interesses. $24^{a}$ ed. São Paulo: Saraiva, 2011. p. 53. 
situação fática comum como uma relação jurídica incidente sobre a hipótese; mas o grupo lesado compreende apenas os moradores da região atingida - e, no caso, esse será o elo fático que caracterizará o interesse difuso do grupo. Tomemos outro exemplo: uma propaganda enganosa pela televisão relaciona-se, sem dúvida, com questões fáticas e jurídicas; contudo, o que reúne o grupo para fins de proteção difusa é o fato de seu acesso efetivo ou potencial à propaganda enganosa.

Ada Pellegrini Grinover ${ }^{91}$ ensina que os direitos difusos são aqueles:

indeterminados pela titularidade, indivisíveis com relação ao objeto, colocados no meio do caminho entre os interesses públicos e os privados, próprios de uma sociedade de massa e resultado de conflitos de massa, carregados de relevância política e capazes de transformar conceitos jurídicos estratificados, como a responsabilidade civil pelos danos causados no lugar da responsabilidade civil pelos prejuízos sofridos, como a legitimação, a coisa julgada, os poderes e a responsabilidade do juiz e do Ministério Público, o próprio sentido da jurisdição, da ação, do processo.

Hermes Zaneti Jr. assevera que: ${ }^{92}$

tem-se por direitos difusos (art. $81, \S$ único, I, do $\mathrm{CDC}$ e art. $1^{\circ}$, I, do $\mathrm{CM}$ ) aqueles transindividuais (metaindividuais, supraindividuais, pertencentes a vários indivíduos), de natureza indivisível (só podem ser considerados como um todo), e cujos titulares sejam pessoas indeterminadas (ou seja, indeterminabilidade dos sujeitos, não há individuação) ligadas por circunstâncias de fato, não existe um vínculo comum de natureza jurídica, v.g., a publicidade enganosa ou abusiva, veiculada através de imprensa falada, escrita ou

91 GRINOVER, Ada Pellegrini. Os Processos Coletivos nos Países de Civil Law e Common Law: uma análise de direito comparado. São Paulo: Ed. RT, 2008, p. 229.

92 ZANETTI JR., Hermes. Direitos coletivos lato sensu: a definição conceitual dos direitos difusos, dos direitos coletivos stricto sensu e dos direitos individuais homogêneos, http://www.abdpc.org.br/abdpc/artigos/Hermes\%20Zaneti\%20Jr(2)\%20-\%20formatado.pdf 
televisionada, a afetar uma multidão incalculável de pessoas, sem que entre elas exista uma relação jurídica-base.

Veja-se que, no exemplo da publicidade enganosa supramencionado por Zaneti, a conexão ocorre por conta da lesão em si e não do vínculo presente entre os atingidos ou em relação à parte adversa. Tal característica configura a tutela de um direito difuso.

A proteção buscada no caso dos interesses difusos é ampla, sempre tendo em vista os sujeitos atingidos como indeterminados e indetermináveis para fins de proteção de seus interesses. Tal característica de referidos direitos gera discussão quanto à possibilidade de tutela destes em sede de mandado de segurança coletivo, vez que um dos requisitos para a impetração do mandamus é justamente a existência de "direito líquido e certo".

Pode-se, assim, estabelecer certas características principais dos direitos difusos: (i) ausência de vínculo associativo; (ii) indeterminação dos seus titulares; (iii) conflito de ampla abrangência; (iv) impossibilidade de individualização dos lesados e das lesões especificamente ocorridas e (v) vínculo dos interessados por conta de um fato. ${ }^{93}$

Os direitos coletivos stricto sensu, por outro lado, estão relacionados a um grupo de pessoas de uma categoria determinada ou determinável, que possuem uma relação jurídica que as vincula. A tutela de tais interesses está prevista no art. 81, parágrafo único, inciso II do $\mathrm{CDC}^{94}$ e no art. 21, parágrafo único, inciso I, da Lei 12.016/2009 ${ }^{95}$ (no que concerne à tutela específica em sede de mandado de segurança coletivo).

Sobre o ponto, Hugo Nigro Mazzilli ensina que "embora o CDC se refira a ser uma relação jurídica básica o elo comum entre os lesados que comunguem o mesmo interesse coletivo (tomado em seu sentido estrito), ainda aqui é preciso admitir que essa relação

${ }^{93}$ GOMES JR., Luiz Manoel e FAVRETO, Rogério. Mandado de segurança coletivo - Legitimidade e objeto - Análise dos seus principais aspectos - Lei 12.016/2009, v. 898, São Paulo: Ed. RT, 2010, p. 103.

${ }^{94}$ Art. 81

(...) II - interesses ou direitos coletivos, assim entendidos, para efeitos deste código, os transindividuais, de natureza indivisível de que seja titular grupo, categoria ou classe de pessoas ligadas entre si ou com a parte contrária por uma relação jurídica base;

${ }^{95}$ Art. 21. (..)

Parágrafo único. Os direitos protegidos pelo mandado de segurança coletivo podem ser:

I - coletivos, assim entendidos, para efeito desta Lei, os transindividuais, de natureza indivisível, de que seja titular grupo ou categoria de pessoas ligadas entre si ou com a parte contrária por uma relação jurídica básica; 
jurídica disciplinará inevitavelmente uma hipótese fática concreta; entretanto, no caso de interesses coletivos, a lesão ao grupo não decorrerá propriamente da relação fática subjacente, e sim da própria relação jurídica viciada que une o grupo. Exemplifiquemos com uma cláusula ilegal em contrato de adesão. A ação civil pública que busque a nulidade dessa cláusula envolverá uma pretensão à tutela de interesse coletivo em sentido estrito, pois o grupo atingido estará ligado por uma relação jurídica básica comum, que, nesse tipo de ação, deverá necessariamente ser resolvida de maneira uniforme para todo o grupo lesado." 96

Os direitos coletivos stricto sensu representam, pois, direitos de natureza indivisível, de titularidade de um determinado grupo de pessoas que se unem por conta de uma relação jurídica. Referida relação jurídica pode se dar em função do grupo de per si ou pela sua ligação com a parte adversa.

Importante verificar a distinção entre os interesses difusos e os coletivos. No caso dos interesses coletivos, a determinação dos sujeitos é pressuposto essencial, assim como a existência de uma relação jurídica que os vincula. Embora haja uma situação fática decorrente desta relação jurídica, a proteção do interesse se dará em função do vício nesta e não naquela.

Assim, há uma relação jurídica base que une os indivíduos, como: pertencer a uma associação, ou ser membro de um sindicato.

No caso dos direitos difusos, não há vínculo jurídico entre os integrantes do grupo, que se conectam tão somente por conta da situação de fato. Referidos direitos estão, via de regra, ligados a questões amplas como meio ambiente, consumidores, religião, etnia, patrimônio histórico e cultural.

Note-se que, nada obstante as diferenças existentes entre direitos difusos e coletivos, ambos são transindividuais/metaindividuais caracterizando-se fundamentalmente por sua indivisibilidade e por extravasar o âmbito do indivíduo em si.

96 MAZZILLI, Hugo Nigro. A defesa dos interesses difusos em juízo: meio ambiente, consumidor e patrimônio cultural, patrimônio público e outros interesses. $24^{\mathrm{a}}$ ed. São Paulo: Saraiva, 2011, p. 55. 
Sobre o tema, a definição de Ada Pellegrini Grinover ${ }^{97}$, ao tratar de direitos difusos e coletivos, ensina que:

A diferença consiste em que se entendem por interesses difusos aqueles em que não há nenhum vínculo jurídico entre as pessoas pertencentes ao grupo, ligadas que são apenas por circunstâncias de fato, contingentes e variáveis, como as de habitarem a mesma região ou o mesmo bairro, participarem de certos empreendimentos, consumirem determinados produtos. Situam-se nessa espécie interesses espalhados e muito amplos: por exemplo, os que têm por objeto a proteção ao ambiente, aos consumidores, aos usuários de serviços públicos.

Já nos interesses chamados coletivos, existe um vínculo jurídico, ou uma relação jurídica base, que une as pessoas pertencentes ao grupo, como os filiados a um sindicato, os membros de uma entidade associativa, as pessoas interessadas na preservação ambiental ou na eliminação da propaganda enganosa, que se associam para a defesa de seus interesses de categoria ou de classe.

A par das situações caracterizadoras de violação de direitos difusos e coletivos, por vezes surgem indivíduos titulares de direitos individuais que sofreram ou estão ameaçados de sofrer lesão coletivamente causada, cuja homogeneidade dos direitos e abrangência dos envolvidos é tamanha que permite o tratamento coletivo da questão.

Referida hipótese foi reconhecida pela doutrina e pela legislação brasileira como de tutela de direitos individuais homogêneos, que teve origem nas class actions norteamericanas. Referida categoria foi criada para permitir a proteção coletiva (molecular) de direitos individuais com dimensão coletiva.

${ }^{97}$ GRINOVER, Ada Pellegrini. Mandado de segurança coletivo: legitimação, objeto e coisa julgada. São Paulo: Saraiva, 1991, p. 287. 
O legislador definiu os direitos individuais homogêneos no art. 81, parágrafo único, inciso III, do CDC e no art. 22, parágrafo único, inciso II, da Lei 12.016/2009 (no que concerne à tutela específica em sede de mandado de segurança coletivo ${ }^{98}$ ).

Referidos direitos são aqueles que Rodolfo de Camargo Mancuso, ao citar José Carlos Barbosa Moreira, se refere como "acidentalmente coletivos"99. Tais interesses possuem uma "origem comum" (art. 81, inciso III do $\mathrm{CDC}^{100}$ ), uma situação fática que une os indivíduos, porém estes são determinados ou determináveis, com direitos plenamente divisíveis. Tal tutela tem origem nas class actions do direito norte-americano.

Um exemplo clássico é o caso em que várias pessoas sofrem danos por conta de acidente decorrente de um defeito de fábrica em determinado modelo de veículo que compraram. Cada pessoa é titular de um direito individual, que se mostra homogêneo (e possível de ser tutelado em demanda coletiva) por conta de sua origem fática comum.

Veja-se que, neste caso, cada sujeito alvo de dano poderia buscar sua tutela individualmente, porém possibilitou-se a sua tutela coletiva, como forma de se proferir uma só decisão, comum, que atenda aos interesses de todos os atingidos de forma isonômica.

Para Humberto Theodoro Jr., nos direitos individuais homogêneos:

Desde a origem se pode identificar a titularidade do direito pelo indivíduo, sem conotação alguma com o grupo que posteriormente se confirmou apenas para efeito de atuação em juízo. A reunião dos interessados decorre apenas de medida de economia processual, tal como ocorre tradicionalmente com o litisconsórcio. É claro, porém, que uma ação coletiva, mesmo de tutela de direitos individuais homogêneos, não se confunde com o litisconsórcio, porque não se

\footnotetext{
${ }^{98}$ Art. 21. (...)

Parágrafo único. Os direitos protegidos pelo mandado de segurança coletivo podem ser:

II - individuais homogêneos, assim entendidos, para efeito desta Lei, os decorrentes de origem comum e da atividade ou situação específica da totalidade ou de parte dos associados ou membros do impetrante.

${ }_{99}$ MANCUSO, Rodolfo de Camargo. Manual do consumidor em juízo. 2 ed. São Paulo: Saraiva, 1998. p. 8.

${ }^{100}$ Art. 81

(...) III - interesses ou direitos individuais homogêneos, assim entendidos os decorrentes de origem comum.
} 
trata de simples reunião de várias pessoas para defenderem, em conjunto, seus direitos individuais. É certo que a previsão de ação coletiva na espécie não anula a possibilidade do indivíduo preferir o exercício da ação individual, nem impede que a solução da demanda possa ser diferente para algum interessado figurante do grupo. Justamente porque, na raiz, os direitos congregados são individuais e podem, caso a caso, sofrer reflexos de circunstâncias pessoais.

Referidos direitos são reconhecidos, via de regra, em situações de impacto de massa, em que, apesar de se poder determinar os indivíduos envolvidos, os aspectos coletivos predominam sobre os individuais, havendo grandes repercussões na comunidade, que exijam o tratamento comum das questões.

A defesa de tais interesses pode ser realizada em demanda coletiva, em diversas demandas coletivas (dependendo da abrangência do objeto destas) ou até mesmo em diversas demandas individuais. Por outro lado, por decisão política, em algumas situações não se permitiu a tutela coletiva destes interesses por determinados legitimados, mesmo que tais direitos, a priori, aparentem ser individuais e homogêneos.

\subsection{A tutela de direitos difusos em sede do Mandado de Segurança Coletivo}

Como visto, o art. $5^{\circ}$, LXX, da CF previu a hipótese de legitimação ativa dos partidos políticos (alínea "a") e dos sindicatos, entidades de classe ou associações legalmente constituídas e em funcionamento há pelo menos um ano, "em defesa dos interesses de seus membros ou associados".

Em capítulo específico será abordada a questão relativa à discussão sobre o termo "interesses" trazido pelo dispositivo constitucional supramencionado. Adiante-se, apenas, que, apesar da menção constitucional à tutela de "interesses", o mandado de segurança coletivo se presta à preservação de direitos materiais e não a interesses. Trata-se da tutela de direitos subjetivos dos substituídos, cujo substrato material relaciona-se ao ente legitimado extraordinariamente. 
O que importa para a análise nesse momento é a definição do escopo desses "interesses", exatamente para fim de estabelecimento das hipóteses em que cabível o mandado de segurança coletivo e dos direitos a serem tutelados.

Muita discussão doutrinária e jurisprudencial houve sobre o tema. Embora tenha sido amplamente aceita a impetração de mandado de segurança coletivo no caso de direitos coletivos stricto sensu e de direitos individuais homogêneos, os juristas dividiram-se quanto à possibilidade de impetração do mandamus no caso de direitos difusos, alguns defendendo que seria possível tal figura e outros rejeitando-a.

A discussão acirrou-se quando editada a Lei 12.016/2009, que regulamentou o mandado de segurança individual e coletivo, trazendo não apenas os requisitos para sua impetração e os legitimados, mas também os interesses e direitos a serem tutelados.

$\mathrm{O}$ art. 21, parágrafo único, incisos I e II da Lei 12.016/2009 ${ }^{101}$ expressamente previu o cabimento de mandado de segurança para proteção de direitos coletivos stricto sensu e direitos individuais homogêneos.

A referência expressa a tais direitos e a exclusão à menção dos direitos difusos corroboraram o argumento dos juristas que defendiam a impossibilidade do writ nessa hipótese. Referidos autores suscitaram, inclusive, que a supressão dos direitos difusos seria propositada, um silêncio eloquente da norma.

Nesse passo, ante a ausência de definição na Constituição Federal sobre os direitos tuteláveis por meio de mandado de segurança coletivo e considerado o texto expresso da Lei 12.016/2009 (mencionando apenas direitos coletivos e individuais homogêneos), houve grande indagação sobre o cabimento da medida em relação aos direitos difusos.

\footnotetext{
${ }^{101}$ Art. $21(\ldots)$
}

Parágrafo único. Os direitos protegidos pelo mandado de segurança coletivo podem ser:

I - coletivos, assim entendidos, para efeito desta Lei, os transindividuais, de natureza indivisível, de que seja titular grupo ou categoria de pessoas ligadas entre si ou com a parte contrária por uma relação jurídica básica; II - individuais homogêneos, assim entendidos, para efeito desta Lei, os decorrentes de origem comum e da atividade ou situação específica da totalidade ou de parte dos associados ou membros do impetrante. 
A discussão se deu também porque os dispositivos legais vigentes mencionavam a tutela por sindicatos, entidades de classe e associações a "interesses de seus membros e associados" e dos partidos políticos (na Lei 12.016/2009) à defesa de seus interesses legítimos "relativos a seus integrantes" ou à "finalidade partidária". Como os direitos difusos compreenderiam sujeitos indeterminados e indetermináveis para fins de proteção de seus interesses, afirmou-se que partidos políticos, sindicatos, entidades de classe e associações não estariam legalmente autorizados a defender tais direitos, já que a normatização vigente exigiria a determinação dos sujeitos envolvidos, exatamente para identificar o interesse desse grupo relacionado ao interesse da entidade. A necessidade de tutela de "direito líquido e certo" não se coadunaria com a figura dos direitos difusos, cujos titulares não são especificamente determinados e/ou determináveis. Suscitou-se, ainda, que os direitos difusos seriam resguardados por outros meios processuais, como a ação civil pública, o que seria mais um argumento a justificar a impossibilidade do mandamus.

Outro ponto levantado para apoiar a tese em referência referiu-se à suposta incompatibilidade entre os direitos difusos e o requisito do "direito líquido e certo" previsto para impetração do writ. Como os direitos difusos são amplos e fluidos, não seriam compatíveis com o conceito de "direito líquido e certo".

Nesse passo os autores adeptos dessa corrente doutrinária defendem que os sindicatos, associações e entidades de classe somente poderiam ir a juízo para: (i) impetrar mandado de segurança individual como representante do associado cujo direito fora violado, desde que devidamente autorizadas por este (art. 5, XXI, da CF); (ii) impetrar writ individual para tutela de interesse da própria entidade (art. $5^{\circ}, \mathrm{LXIX}, \mathrm{CF}$ ); ou (iii) impetrar mandado de segurança coletivo, nos termos do art. $5^{\circ}$ LXX, "b", para a defesa de direitos individuais líquidos e certos dos associados, os quais permaneceriam "indeterminados" na inicial, embora "determináveis", caso em que a entidade atuaria como substituta processual.

Ernane Fidélis dos Santos ${ }^{102}$ defende referida corrente doutrinária, asseverando que:

${ }^{102}$ SANTOS, Ernane Fidelis. Mandados de segurança e de injunção, São Paulo: Saraiva, 1990, p. 132. 
O que, na verdade, aconteceu é que a lei constitucional, ao admitir o "mandado de segurança coletivo", não lhe deu extensão tal que também passasse a ser forma de proteção de interesses difusos propriamente ditos. Continua o mandamus a ser forma própria para deduzir pretensão de reconhecimento de "direitos individuais", podendo apenas haver a proteção de tais direitos dimensionados coletivamente, isto é, direito que o indivíduo, parceladamente, com pretensão própria, pode defender, mas que, em visão conjunta, revela interesse de todo um grupo determinado, ainda que seja toda a coletividade. Se o Poder Público, por exemplo, aumenta ilegalmente preços ou tarifas públicas, cada membro da coletividade que, efetiva ou potencialmente, vai do serviço se utilizar, é parte legítima para requerer a redução específica que vai beneficiá-lo; mas, se o pedido individual tiver bom êxito, o aumento abusivo do preço ou da tarifa somente com relação ao impetrante receberá vedação. Pelo contrário, se o mandado for coletivo, interposto por "substituto processual" autorizado, o benefício será geral, se o pedido for julgado procedente.

No mesmo sentido o entendimento de José Rogério Cruz e Tucci ${ }^{103}$ :

Foi, portanto, mantido o elemento essencial e preponderante à caracterização do mandado de segurança, ou seja, o objetivo de tutela ao direito afirmado líquido e certo, tipificado o mandado de segurança coletivo pela circunstância de destinar-se à defesa do direito não de um, ou de vários dos (afirmados) titulares, mas sim dos direitos homogêneos dos indivíduos integrantes de uma coletividade, sujeitos de direito ainda indeterminados quando do ajuizamento do writ, mas necessariamente determináveis quando da execução da ordem, se concedida.

Athos Gusmão Carneiro também entende que o mandado de segurança coletivo é “de todo inadmissível, relativamente aos chamados 'direitos' ou 'interesses difusos', para cuja tutela outro remédio jurídico deve ser utilizado, a ação civil pública". ${ }^{104}$

${ }^{103}$ CRUZ E TUCCI, José Rogério. Class action e mandado de segurança coletivo. São Paulo: Saraiva, 1990, n. 2.2 e 2.6 . 
Uadi Lamêgo Bulos, também entende "impertinente a utilização do writ coletivo para tutelar interesses difusos, os quais são perfeitamente protegidos por outros meios processuais, valendo destacar a ação civil pública (Lei 7.347/1985)". ${ }^{105}$

Nada obstante o entendimento dos juristas acima elencado, mostra-se bastante adequada a tese que defende a possibilidade de mandado de segurança para tutela de direitos difusos.

O fato de existir a possibilidade de tutela de referidos direitos por outros meios processuais, como a ação civil pública não é argumento razoável para elidir a sua proteção também em sede de mandado de segurança coletivo.

Quanto ao argumento da necessidade de existência de um "direito líquido e certo", notoriamente que se tal direito é reconhecido em relação a um indivíduo, também será verificado em relação a uma coletividade. A prova pré-constituída da situação lesiva, que dê substrato ao direito a ser tutelado e à ocorrência de sua violação nos parecem totalmente razoáveis, apesar de sua dificuldade em algumas hipóteses específicas.

É exatamente nesse sentido o entendimento de Cassio Scarpinella Bueno, que defende o cabimento de mandado de segurança coletivo também para tutela de direitos difusos. $^{106}$

Lucia Valle Figueiredo ${ }^{107}$ também compartilha do entendimento de que:

(...) o mandado de segurança coletivo, previsto na Constituição Federal, pode tratar de direito coletivo ou de direito difuso, mas aplica-se melhor para direito coletivo, exceção feita, pelo que disse, dos partidos políticos que normalmente vão postular direitos difusos.

104 CARNEIRO, Athos Gusmão. Anotações sobre o mandado de segurança coletivo. Ajuris 54/55. Porto Alegre: Ajuris, mar. 1992.

105 BULOS, Uadi Lamêgo. Mandado de segurança coletivo: em defesa dos partidos políticos, associações, sindicatos, entidades de classe: Doutrina, jurisprudência e legislação. São Paulo: Ed. RT, 1996, p. 64. ${ }^{106}$ BUENO, Cássio Scarpinella. A nova lei do Mandado de Segurança, São Paulo: Saraiva, 2009, p.28

107 FIGUEIREDO, Lucia Valle. Mandado de segurança coletivo. Revista de Direito Público 3/1993. São Paulo: Malheiros, 1993, p. 155. 
Suponhamos uma sociedade de meio ambiente. Uma sociedade de meio ambiente essencialmente defende direito difuso. Se o direito for pré-constituído e não houver controvérsia de fato, poderia ser por mandado de segurança coletivo.

Nesse mesmo sentido Calmon de Passos que assevera que os direitos que podem ser objeto do mandado de segurança coletivo são os mesmos direitos que comportam defesa pelo mandado de segurança individual, aduzindo a plena possibilidade do mandado de segurança coletivo para proteção de direitos difusos. ${ }^{108}$

Celso Agrícola Barbi ${ }^{109}$ também defende a ampliação do mandado coletivo à defesa de quaisquer direitos ou interesses legítimos, difusos ou coletivos.

Marta Maria Gomes Silva e Lucas de Souza Lehfeld ${ }^{110}$ defendem a possibilidade do writ para tutela de direito difuso, afirmando que:

(...) não nos mostra procedente que um instrumento processual anule, exclua, afaste o uso de outro se o intuito deve ser exatamente o oposto, qual seja: o de dotar o ordenamento jurídico de instrumentos efetivos de tutela coletiva, mesmo que isso venha a implicar a existência de mais de um meio processual para a defesa dos mesmos direitos.

Referidos autores também aduzem que inexistiria incompatibilidade entre a liquidez e certeza do direito (pressuposto para impetração do mandamus) e a natureza dos direitos difusos:

Cremos que o óbice à vinculação do pressuposto constitucional ao fato de estar em jogo a defesa de um direito difuso não se sustenta. A

108 CALMON DE PASSOS, José Joaquim. Mandado de Segurança Coletivo, Mandado de Injunção e Habeas Data - Constituição e Processo, Rio de Janeiro: Forense, 1989, p. 16.

${ }^{109}$ BARBI, Celso Agrícola. Mandado de segurança na Constituição de 1988. São Paulo: Saraiva, 1990, p. 73 ${ }^{110}$ SILVA, Marta Maria Gomes e, LEHFELD Lucas de Souza. A legitimação ativa no mandado de segurança coletivo e a Lei 12.016/2009, Revista de Direito Constitucional e Internacional, vol. 70, São Paulo: Ed. RT, 2010, p. 143 e ss. 
errônea percepção baseia-se na afirmação de que os interesses difusos por dizerem respeito a objeto indivisível ou de natureza indivisível não comporta a apuração do direito líquido e certo, pois como seus efetivos titulares são impossíveis de serem identificados entende-se como não cabível a ação mandamental para referida espécie de interesses.

Todavia, a noção de direito líquido e certo - segundo nosso entendimento - ainda que relacionada a uma pretensão difusa, mostrase como o direito deduzido com plausibilidade e comprovado documentalmente de início, com a desnecessidade de eventuais dilações probatórias ou de maiores perquirições em relação à matéria fática ali disposta pelo ente colegitimado. Em vista disso, uma vez substancialmente demonstradas, quando da impetração, a existência e a possibilidade de comprovação do direito difuso alegado, bem como a ilegalidade ou abuso de poder por parte de autoridade ou de agente de pessoa jurídica no exercício de atribuição do Poder Público, não há que se tentar vincular a necessidade de identificação dos titulares ao direito material invocado.

No mesmo sentido Luiz Rodrigues Wambier e Rita de Cássia Corrêa de Vasconcelos $^{111}$ :

É certo que os entes legitimados podem ter, entre seus fins institucionais, a proteção de direitos que atinjam a todos os seus membros ou associados, de forma indivisível, sem que entre eles - ou em relação à parte contrária - haja uma relação jurídica base. Cite-se, como exemplo, a atuação de um partido político que se volta contra uma propaganda eleitoral de cunho racista. Trata-se de direito verdadeiramente difuso, pois coibir o racismo interessa à sociedade, ou seja, a todos os membros da coletividade, indistintamente. A propósito, deve-se considerar que o próprio regime democrático é direito difuso, e não poderia ser excluída sua proteção, pelos partidos

${ }^{111}$ WAMBIER, Luiz Rodrigues; e VASCONCELOS, Rita de Cássia Corrêa de. O mandado de segurança na disciplina da Lei 12.016, de 07.08.2009, Revista de Processo, v. 177, São Paulo: Ed. RT, 2009, p. 185 e ss. 
políticos, através do mandado de segurança coletivo. Em suma, entendemos que se deve desconsiderar a omissão da lei, em relação aos direitos difusos, admitindo-se o mandado de segurança coletivo para a tutela dos direitos coletivos em sentido lato.

Verificado o entendimento doutrinário supra e conforme já mencionado anteriormente, é plenamente defensável a impetração de mandado de segurança coletivo para tutela de direitos difusos.

\section{A legitimação para proteção dos interesses coletivos}

É de extrema importância para defesa dos interesses coletivos a definição dos legitimados para sua tutela em juízo.

Embora já tenham sido mencionados nesse trabalho alguns dos pontos adiante tratados, serão rememorados alguns conceitos e entendimentos apenas com o intuito de os correlacionar aos legitimados e sua forma de atuação, tema que se seguirá nos capítulos seguintes.

Consoante já tratado nesse trabalho, o sistema processual brasileiro define a legitimação com base na lei (ope legis). A Constituição Federal e demais diplomas pátrios definem expressamente os legitimados, embora doutrina e jurisprudência acabem por definir, no caso concreto, a possibilidade de atuação de determinados entes (a partir da interpretação da lei posta, mas sempre respeitando as hipóteses previamente estabelecidas legalmente). Nos países da common law a definição dos legitimados se dá no caso concreto, sendo verificada pelo Tribunal a adequação da representação para o caso específico. Kazuo Watanabe ${ }^{112}$ defende a ideia desta representação adequada, fundado no sistema norte-americano (ope judicis).

Como visto, no que tange à natureza jurídica da legitimação em sede de ação coletiva, a maioria da doutrina pátria defende tratar-se esta de extraordinária. Sobre o ponto, Pedro Lenza assevera que "ao que parece, a grande maioria da doutrina posiciona-se

${ }^{112}$ WATANABE, Kazuo. Código de Defesa do Consumidor comentado pelos autores do anteprojeto. Rio de Janeiro: Forense Universitária, 2004, p.824. 
pela legitimação extraordinária nas ações coletivas, havendo substituição processual da coletividade. Nesse sentido, destaquem-se Grinover, Dinamarco, Yarshell, Zavaski, Vigliar, Pedro da Silva Dinamarco e Ephraim de Campos Jr." ${ }^{\prime 13}$.

Importante pontuar, contudo, o entendimento diverso trazido por alguns doutrinadores, como Luiz Marinoni e Nelson Nery Jr., que defendem que na ação coletiva não ocorre uma efetiva substituição processual para a tutela dos interesses envolvidos.

Luiz Marinoni defende a tese de uma nova conceituação para a legitimação extraordinária, ao afirmar que

não se pode conceber o processo coletivo sob a perspectiva da ação individual, nem se pode aplicar indiscriminadamente as noções do processo individual para a tutela coletiva. De fato, não há razão para tratar da legitimidade para a tutela dos direitos transindividuais (ou mesmo dos direitos individuais homogêneos) a partir de seu correspondente no processo civil individual. Quando se pensa em 'direito alheio', raciocina-se a partir de uma visão individualista, que não norteia a aplicação da tutela coletiva. Não só a partir da premissa de que apenas o titular do direito material está autorizado a ir a juízo, mas principalmente a partir da ideia de que somente há direitos individuais. A noção de direitos transindividuais, como é óbvio, rompe com a noção de que o direito ou é próprio ou é alheio. Se o direito é da comunidade ou da coletividade, não é possível falar em direito alheio, não sendo mais satisfatória, por simples consequência lógica, a clássica dicotomia que classifica a legitimidade em ordinária e extraordinária. ${ }^{114}$

Já Nelson Nery Júnior e Rosa Maria de Andrade Nery defendem a tese da "legitimação autônoma para condução do processo":

\footnotetext{
${ }^{113}$ LENZA, Pedro. Teoria Geral da Ação Civil Pública. São Paulo: Ed. RT, 2003, p. 179/180.

${ }^{114}$ MARINONI, Luiz Guilherme. Manual do processo de conhecimento. 4. ed. São Paulo: Ed. RT, 2005. p. 711.
} 
A dicotomia clássica legitimação ordinária-extraordinária só tem cabimento para a explicação de fenômenos envolvendo direito individual. Quando a lei legitima alguma entidade a defender direito não individual (coletivo ou difuso), o legitimado não estará defendendo direito alheio em nome próprio, porque não se pode identificar o titular do direito. Não poderia ser admitida ação judicial proposta pelos 'prejudicados pela poluição', pelos 'consumidores de energia elétrica', enquanto classe ou grupo de pessoas. A legitimidade para a defesa dos direitos difusos e coletivos em juízo não é extraordinária (substituição processual), mas sim legitimação autônoma para a condução do processo (selbständige Prozebführungsbefgnis): a lei elegeu alguém para a defesa de direitos porque seus titulares não podem individualmente fazê-lo. ${ }^{115}$

Superada tal questão, importante observar quais são as pessoas efetivamente legitimadas para atuação em juízo na defesa dos interesses coletivos.

Inicialmente se diga que, nada obstante a Lei de Ação Popular (Lei 4.717/65) permita ao cidadão que promova ação para coibir atos lesivos ao erário público, em uma ideia de proteção do interesse da coletividade, sua atuação não tem se mostrado tão eficaz. Os demais instrumentos de proteção dos interesses coletivos têm, inclusive, afastado a possibilidade do indivíduo de per si atuar em prol da tutela coletiva.

Kazuo Watanabe discorre sobre o tema, asseverando quais os fundamentos que conduziram o legislador a excluir a possibilidade da legitimação individual para a tutela coletiva:

Pelas regras que disciplinam as obrigações indivisíveis, seria admissível, em linha de princípio, a legitimação concorrente de todos os indivíduos para defesa dos interesses difusos ou coletivos de natureza indivisível. Mas ponderações várias, como as pertinentes ao conteúdo político das demandas, à possibilidade de pressões quanto à propositura e prosseguimento da demanda, à produção de prova

${ }^{115}$ NERY JÚNIOR, Nelson, Código de processo civil comentado. 5. ed. São Paulo: Ed. RT, 2001, p. 1866. 
adequada e ao prosseguimento destemido nas instâncias superiores, e à necessidade, enfim, de um fortalecimento do autor da demanda coletiva, fizeram com que se excluísse a legitimação individual para a tutela coletiva dos consumidores a título coletivo. ${ }^{116}$

É exatamente esse espírito que se verifica no rol de legitimados trazido pela Constituição Federal, Lei da Ação Civil Pública, Código de Defesa do Consumidor e Lei do Mandado de Segurança.

Os legitimados para a ação coletiva são: o Ministério Público, a Defensoria Pública, União, Estados, Municípios e o Distrito Federal, as entidades e órgãos da administração pública direta e indireta, ainda que sem personalidade jurídica, e associações que estiverem constituídas há pelo menos um ano e incluam, entre suas finalidades institucionais, a proteção ao meio ambiente, ao consumidor, à ordem econômica, à livre concorrência ou ao patrimônio artístico, estético, histórico, turístico e paisagístico (art. 129, III da CF, art. $5^{\circ}$ da Lei 7.347/85 e art. 82 do CDC).

No caso da ação popular, como já referido, qualquer cidadão poderá promovê-la, nos termos do art. $1^{\circ}$ da Lei $4.717 / 65$ e art. $5^{\circ}$, LXXIII, CF.

No caso do mandado de segurança coletivo, objeto deste trabalho, são legitimados os partidos políticos, organizações sindicais, entidades de classe e as associações legalmente constituídas e em funcionamento há pelo menos um ano, em defesa dos interesses de seus membros ou associados (art. 5. ${ }^{\circ}$, LXX, da CF). Referido rol de legitimados está previsto também na Lei 12.016/09. A legitimação dos partidos políticos foi aparentemente limitada por referida norma, ao trazer disposição específica sobre a "necessidade de a representação estar relacionada a questões de interesse do partido ou de seus filiados" $" 117$, o que não era previsto em sede constitucional. Tal limitação é combatida em parte pela doutrina pátria.

\footnotetext{
${ }^{116}$ WATANABE, Kazuo. Código de Defesa do Consumidor comentado pelos autores do anteprojeto. Rio de Janeiro: Forense Universitária, 2004, p. 815.

117 Art. 21. O mandado de segurança coletivo pode ser impetrado por partido político com representação no Congresso Nacional, na defesa de seus interesses legítimos relativos a seus integrantes ou à finalidade partidária, ou por organização sindical, entidade de classe ou associação legalmente constituída e em funcionamento há, pelo menos, 1 (um) ano, em defesa de direitos líquidos e certos da totalidade, ou de parte,
} 
A doutrina tem explicitado os casos específicos de atuação dos legitimados em sede de mandado de segurança coletivo, conforme a natureza e representatividade de cada um destes. E, mais, tem-se ampliado o rol legalmente previsto de legitimação, passando-se a permitir a tutela em situações não estabelecidas expressamente pela lei do mandado de segurança.

\section{A legitimação ativa em tutelas coletivas em outros países}

Embora não seja o escopo do presente trabalho, faremos menções pontuais sobre a legitimação ativa em outros países. A intenção não é, de nenhuma forma, aprofundar ou exaurir o tema, mas apenas trazer algumas curiosidades bastante superficiais sobre tendências estrangeiras de legitimação em alguns países que seguem o modelo da civil law.

Nos países europeus, como Alemanha, França, Itália, a legitimidade para demanda coletiva é exclusiva de pessoas físicas e/ou entes privados. No caso específico da França, a legitimação é exclusiva das associações ${ }^{118}$.

Em modelo semelhante, o Japão também adota a legitimidade da pessoa física e dos entes privados, exigindo que as associações de consumidores tenham aprovação prévia do Primeiro Ministro.

Os demais países de civil law seguem um modelo de legitimação mista. Em alguns deles, atribui-se a órgãos públicos a função de fiscalização da regularidade do processo e da atuação do legitimado, sendo que o abandono da causa por este gera a assunção pelo órgão público do polo passivo da demanda. ${ }^{119}$

O México adota um sistema peculiar em que as tutelas de consumidor possuem legitimação pública e as causas agrárias são legitimadas de forma privada.

dos seus membros ou associados, na forma dos seus estatutos e desde que pertinentes às suas finalidades, dispensada, para tanto, autorização especial.

118 GRINOVER, Ada Pellegrini. Novas tendências em matéria de ações coletivas nos países de Civil Law, Doutrinas Essenciais de Processo Civil, v. 9, São Paulo: Ed. RT, 2011, p. 1101 e ss.

${ }^{119}$ GRINOVER, Ada Pellegrini. Novas tendências em matéria de ações coletivas nos países de Civil Law, Doutrinas Essenciais de Processo Civil, v. 9, São Paulo: Ed. RT, 2011, p. 1101 e ss. 
No caso, a legitimação pública tem por viés realizar um controle efetivo da adequada representação e atuação em juízo. Por esta razão, muitos países adotam um sistema de legitimação mista, permitindo a ampliação do rol de legitimados e da atuação dos entes privados, mas prevendo a limitação desta atuação ou mesmo sua substituição através órgãos públicos nas causas de maior relevo social e interesse da coletividade.

O que se verifica, pois, é a tendência de ampliação do rol de legitimados, mas a manutenção de sistemas efetivos de controle destes, para que a proteção dos interesses coletivos ocorra de forma efetiva e tecnicamente adequada, sem prejuízo aos direitos defendidos em juízo e a seus titulares.

\section{A legitimação no Mandado de Segurança Coletivo no Brasil}

Consoante visto anteriormente neste trabalho, o mandado de segurança surgiu como meio eficaz para impugnação dos atos abusivos cometidos pela Administração Pública através de seus agentes, obstando a eficácia de tais atos e permitindo o exercício regular dos direitos dos administrados, quando estes forem líquidos e certos.

A pretensão do impetrante é exatamente a de que o agente (por si ou por seus comandados) se abstenha de realizar determinados atos ou conduta.

Nesse passo, o mandado de segurança objetivava, a priori, a tutela do interesse individual (em sentido lato) do impetrante contra os desmandos do Poder Estatal.

Notoriamente que, por sua natureza, os atos do Poder Público sempre tiveram o potencial de atingir diversos indivíduos, sejam eles determináveis ou não. Ocorre que, quando do surgimento do instituto do mandado de segurança, partiu-se de uma ideia de defesa do indivíduo contra o Estado, razão pela qual se pensou em uma ação da pessoa física contra o ente Público.

Com o passar dos anos e principalmente a partir do surgimento dos denominados "direitos de terceira geração" ou "direitos sociais", o foco da tutela jurídica foi sendo 
modificado, para abarcar não apenas a tutela do indivíduo, mas sim deste como ente integrante de uma coletividade, que pode ter sido afetada em modo e situação semelhantes.

É nesse contexto que foi editada a Constituição Federal de 1988, que deu origem à tutela coletiva em sede de mandado de segurança (art. $5^{\circ}$, LXX).

Note-se que a tutela em questão busca a dirimir o conflito de forma ampla, à maior quantidade de indivíduos possível, para que a lide possa ser sanada.

Referidas mudanças legislativas coadunam-se exatamente com os ensinamentos do i. jurista Rodolfo de Camargo Mancuso. Referido autor defende que a prestação jurisdicional deve ser ampla, de forma a solucionar o litígio como um todo, e não apenas em relação a alguns poucos indivíduos atingidos:

Esse desejável salto de qualidade na prestação jurisdicional faz a diferença entre o singelo "dizer o direito" e a realização equânime da ordem jurídica como um todo, tarefa que ultrapassa os lindes da estrita crise jurídica, para alcançar outros patamares, subjacentes ou pressupostos, tais as insatisfações e incertezas concernentes aos planos social, econômico e político. Só essa postura holística pode garantir que o conflito venha realmente superado, porque, do contrário, os demais pontos de tensão, deixados em aberto, tenderão a formar novas lides, instalando-se um perverso círculo vicioso. ${ }^{120}$

Notório que a tutela dos interesses coletivos tem relevante participação na concretização de tal anseio, através da adoção de uma postura holística em relação aos conflitos existentes.

É necessário, pois, que se busque cada vez mais ampliar o âmbito de atuação da demanda coletiva e de seus legitimados, para que se efetive uma adequada prestação jurisdicional.

${ }^{120}$ MANCUSO, Rodolfo de Camargo. A Resolução dos Conflitos e a Função Judicial no Contemporâneo Estado de Direito, $1^{\mathrm{a}}$ Ed., Ed. RT, São Paulo, 2009, pp. 107-108. 
É fundamental a evolução dos sistemas de defesa dos interesses transindividuais, sendo o mandado de segurança coletivo um dos instrumentos para tal fim.

A Constituição Federal de 1988 cumpriu exatamente referido escopo, ampliando o rol de legitimados para o mandado de segurança, criando, pois, a possibilidade de tutela de direitos coletivos a partir de tal instrumento.

Note-se que a previsão constitucional não implicou a criação de um novo modelo de mandado de segurança (coletivo) alheio ao mandado de segurança individual. Ao contrário, o art. $5^{\circ}$, LXX, da CF apenas alargou as hipóteses de cabimento do mandamus, ao estabelecer novos legitimados para sua impetração. Nada obstante, a Constituição não delimitou o objeto de atuação de referidos legitimados, no que concerne especificamente a direitos difusos, coletivos e individuais homogêneos. A Carta Magna fez menção genérica à defesa de "interesses", denominação que, como se verá, deve ser interpretada como direito subjetivo e não mero interesse.

Nesse sentido, o entendimento de Cassio Scarpinella Bueno, ao aduzir a inocorrência de criação de nova figura ao lado do mandado de segurança individual, "mas apenas hipótese de legitimação para a causa". ${ }^{21}$

O mandado de segurança coletivo é, pois, ação para tutela de direitos coletivos lato sensu em caso de violação ou ameaça a direito líquido e certo por ato de autoridade. $\mathrm{Ou}$ seja, são exigidos os mesmo requisitos do mandado de segurança individual, sendo entendidos direitos "líquidos e certos" aqueles decorrentes de fatos não controvertidos, cuja prova possa ser feita de forma exclusivamente documental.

No mandado de segurança coletivo, o polo ativo será ocupado por um terceiro que não o titular do direito líquido e certo que foi alegadamente violado por ato ilegal ou praticado com abuso de poder, mas sim por "partido político com representação no Congresso Nacional" ou "organização sindical, entidade de classe ou associação legalmente constituída e em funcionamento há pelo menos um ano, em defesa dos

${ }^{121}$ BUENO, Cássio Scarpinella. Mandado de segurança. São Paulo: Saraiva, 2002, p. 28-29. 
interesses de seus membros ou associados", conforme estabelece o art. $5^{\circ}$, LXX, da CF e 21, caput da Lei 12.016/2009.

Sobre o ponto, importante observar que o legislador, com a edição da Lei 12.016/2009, perdeu uma excelente oportunidade para ampliar o rol de legitimados. Ao contrário, ao invés de uma tendência ampliativa, o legislador parece ter agido de forma a restringir o instituto, vez que estabeleceu restrição à atuação dos partidos políticos que não era prevista pela Carta Magna. Foi ilegitimamente estabelecida a condição de o partido atuar "na defesa de seus interesses legítimos relativos a seus integrantes ou à finalidade partidária”. Como se verá em capítulo específico, tal previsão não possui razão de ser, devendo, pois, ser mantida a interpretação por uma legitimação mais ampla do partido político, conforme a norma constitucional.

Outra restrição apontada por alguns doutrinadores e já referida neste trabalho seria referente à menção exclusiva à tutela de direitos coletivos e individuais homogêneos no art. 21, parágrafo único, incisos I e II da Lei. Nada obstante, entende-se que o writ também é cabível nos casos de direitos difusos, consoante já tratado em capítulo específico deste trabalho.

Por outro lado, no que concerne às entidades de classe, sindicato e associações, o legislador sedimentou a orientação já prevista pela doutrina e jurisprudência pátrias sobre a desnecessidade de autorização do associado ou membro da classe para impetração do mandamus coletivo. Tal circunstância afastou a previsão do art. 2-A, parágrafo único, da Lei $9.494 / 97 .{ }^{122}$

Embora tenha implementado algumas alterações pontuais, a Lei 12.016/2009 manteve a menção prevista constitucionalmente relativa à defesa de "interesses dos associados e membros da classe", acrescentando ao partido político a necessidade de proteger os "interesses de seus integrantes".

${ }^{122}$ Art. 2-A (...)

Parágrafo único: Nas ações coletivas propostas contra a União, os Estados, o Distrito Federal, os Municípios e suas autarquias e fundações, a petição inicial deverá obrigatoriamente estar instruída com a ata da assembléia da entidade associativa que a autorizou, acompanhada da relação nominal dos seus associados e indicação dos respectivos endereços. 
Sobre o ponto, consoante já discutido sobremaneira na doutrina pátria, a denominação "interesse" não se adequa à tutela pretendida para os direitos coletivos lato sensu. Há diferença substancial entre direitos e interesses. O interesse é mera pretensão individual, enquanto direito é a pretensão juridicamente protegida.

O mero interesse não pode ser defendido por meio de mandado de segurança, seja individual, seja coletivo. Os interesses podem ser pleiteados apenas na esfera administrativa, não sendo protegidos por norma e, portanto, desprovidos de proteção jurisdicional. $^{123}$

Hermes Zaneti Jr. defende, inclusive, a incorreção da expressão "interesses” na normatização pátria sobre tutela de direitos coletivos. Segundo o autor, tal equívoco decorreu da internalização da expressão doutrinária italiana “interessi legitimi”, sendo que a tutela de interesses, ainda que tais interesses eventualmente sejam protegidos juridicamente, está desprovida de coercibilidade. A hipótese prevista na norma constitucional e infraconstitucional não trataria, pois, de defesa de interesses e, sim, de direitos subjetivos que se encontram previstos na própria Constituição. ${ }^{124}$

A lei 12.016/2009 ratifica tal entendimento, ao aduzir (em seus arts. $1^{\circ}$ e 21, caput) a defesa de "direitos líquidos e certos", relativamente a direito coletivo (Art. 21, § único, inc. I) ou individual homogêneo (Art. 21, § único, inc. II). Note-se que referida lei está amparada também pelas definições contidas no Código de Defesa do Consumidor. A nomenclatura constitucionalmente estabelecida foi complementada pelo CDC que expressamente determina a defesa de direitos ou interesses difusos, coletivos e individuais homogêneos.

No que concerne aos requisitos para impetração do mandado de segurança coletivo, estes se assemelham ao do writ individual, havendo pressupostos genéricos e alguns específicos para o mandamus coletivo. Os pressupostos são: (i) direito líquido e certo, que significa aquele pautado em fatos incontroversos, cujo direito seja demonstrado por meio de prova pré-constituída; (ii) proteção de direitos difusos, coletivos ou individuais

\footnotetext{
${ }^{123}$ CRETELLA JR., José. Do mandado de Segurança Coletivo. Rio de Janeiro: Forense, 1999, pp. 78-79.

124 ZANETI JR., Hermes. Mandado de Segurança Coletivo - Aspectos Controversos, Porto Alegre: Ed.
} Sergio Antonio Fabris, 2001, p. 62-63. 
homogêneos; (iii) ato comissivo ou omisso ilegal ou cometido com abuso de poder por autoridade pública ou agente público; (iv) congruência entre o direito e a finalidade da entidade.

Nesse passo, verifica-se a grande semelhança entre o mandado de segurança individual e o coletivo, sendo que inexistiu a criação de nova categoria protetiva, mas apenas definição de novos legitimados para tutela de categorias específicas de direitos. Nesse passo, o estudo dos legitimados e fundamentos de sua legitimação é de suma importância.

\section{O tema da legitimidade no projeto de Código Brasileiro de Processos}

\section{Coletivos}

Em vista da grande discussão acerca da proteção dos interesses coletivos e do fato de sua normatização ser realizada de forma esparsa (Lei de Ação Civil Pública, Código de Defesa do Consumidor, Lei do Mandado de Segurança e, subsidiariamente, o Código de Processo Civil), muitos autores propuseram a realização de um código específico sobre a matéria.

Os dispositivos legais vigentes que regem as ações coletivas são fracionados e não apresentam elementos básicos unificadores da disciplina dos processos coletivos, quer em seus aspectos processuais, quer materiais.

Tal circunstância, como narrado supra, gerou o interesse dos doutrinadores e estudiosos do tema na busca de uma codificação, o Código Brasileiro de Processos Coletivos. Referida normatização visaria a dar maior efetividade às normas e à tutelas dos direitos coletivos.

O primeiro deles foi Antonio Gidi, que promoveu um estudo sobre o tema e propôs um Anteprojeto de Código publicado na Revista de Processo no ano de 2003. ${ }^{125}$

${ }^{125}$ GIDI, Antonio. Código de Processo Civil Coletivo: um modelo para países de direito escrito, Revista de Processo, n 111. São Paulo: Ed. RT, 2003, p. 194. 
A partir de tal estudo, foram desenvolvidos: (i) o Código Modelo de Processos Coletivos para Ibero-América, de autoria de Ada Pellegrini Grinover, Kazuo Watanabe e Antonio Gidi; (ii) um Anteprojeto de Código Brasileiro de Processos Coletivos, sob a coordenação da professora Ada Pellegrini Grinover na pós-graduação da Universidade de São Paulo; e (iii) um Anteprojeto elaborado pelas Universidades do Estado do Rio de Janeiro (UERJ) e Estácio de Sá (UNESA), sob a coordenação de Aluísio Gonçalves de Castro Mendes.

Por fim, após grande debate sobre o assunto e referidos projetos, o Ministério da Justiça, em dezembro/2008, promulgou a Portaria n $n^{\circ}$ 2.481/08, que constituiu "Comissão Especial composta por juristas, especialistas, membros da Magistratura, Ministério Público, Defensoria Pública e Advocacia com o objetivo de analisar e elaborar proposta de aprimoramento e modernização da legislação material e processual que trate direitos coletivos, difusos e meta-individuais homogêneos para subsidiar o Ministério da Justiça e órgãos do Governo Federal, contemplando os anteprojetos do Código Brasileiro de Processo Coletivo, Código Modelo de Processos Coletivos para Iberoamérica e outras proposições em debate no meio acadêmico e profissional."

A partir dos trabalhos da referida Comissão Especial foi elaborado um projeto de lei de Ações Coletivas (Projeto de Lei 5.139/2009).

Quanto à constitucionalidade, juridicidade e regimentalidade do Projeto, a Câmara dos Deputados não suscitou qualquer vício. Nada obstante, com relação a seu mérito, foi aprovado o Parecer do Deputado José Carlos Aleluia, que assevera que o projeto não merece prosperar.

Atualmente o Projeto se encontra sob análise da Mesa Diretora da Câmara dos Deputados, em vista de recurso apresentado pelo Deputado Antonio Carlos Biscaia contra o parecer favorável à rejeição do Projeto. ${ }^{126}$ 
Neste trabalho traça-se um breve perfil sobre as alterações propostas pelo Projeto de Lei 5.139/09.

O Código de Processo Coletivo tem por viés específico promover o acesso à justiça, ampliando o rol de legitimados para tutela dos interesses coletivos e simplificando o seu procedimento.

Pautado nessa proposta, o projeto propõe o aumento do rol de legitimados, englobando a Ordem dos Advogados do Brasil e os Partidos Políticos, que passam a atuar na defesa dos direitos coletivos. Desenvolve, ainda, mecanismos de proteção aos autores das demandas coletivas, bem como reforça o conceito de interesses difusos, coletivos e individuais homogêneos trazidos pelo $\mathrm{CDC}^{127}$.

No que concerne especificamente à legitimação no mandado de segurança coletivo, o texto normativo trouxe inovação ao incluir expressamente o Ministério Público e a Defensoria Pública no rol de legitimados. Quanto à legitimação das associações, propõe a retirada da exigência de autorização do associado para ingresso com a medida, proposta esta que já foi consubstanciada na Lei 12.016/2009.

Nada obstante a boa intenção do Projeto, houve certa crítica ao seu texto, vez que concederia excessiva liberdade ao magistrado e proteção específica ao autor, que foi vista como violadora da isonomia. Nesse sentido, inclusive, o parecer da Subcomissão da Câmara, que aduziu que o Projeto permitiria ilegitimamente a alteração da ordem das fases processuais e concessão de liminares de ofício, sem oportunidade de defesa ao réu. Entendeu-se, ainda, que a representatividade não fora bem delimitada e que haviam sido concedidos poderes excessivos ao Ministério Público e Defensoria.

\footnotetext{
${ }^{127}$ Art. 2. A tutela coletiva abrange os interesses ou direitos:

I - difusos, assim entendidos os transindividuais, de natureza indivisível, de que sejam titulares pessoas indeterminadas, ligadas por circunstâncias de fato;

II - coletivos em sentido estrito, assim entendidos os transindividuais, de natureza indivisível, de que seja titular grupo, categoria ou classe de pessoas ligadas entre si ou com a parte contrária por uma relação jurídica base; e

III - individuais homogêneos, assim entendidos aqueles decorrentes de origem comum, de fato ou de direito, que recomendem tutela conjunta a ser aferida por critérios como facilitação do acesso à Justiça, economia processual, preservação da isonomia processual, segurança jurídica ou dificuldade na formação do litisconsórcio.
} 
Por esta razão, ao que parece, infelizmente o Projeto está fadado ao insucesso.

\section{O tema da tutela coletiva no projeto de Código de Processo Civil}

O projeto de código (PL no 8.046/2010) traz duas importantes inovações no que concerne aos direitos coletivos, especialmente à tutela de interesses individuais homogêneos.

A primeira delas refere-se ao incidente de coletivização de demandas, denominado: "incidente de resolução de demandas repetitivas", que se deu em cumprimento à ideia de celeridade e instrumentalidade processual, já concretizada pelo incidente de recursos repetitivos.

Referido incidente tem por objetivo não só evitar a tramitação de milhares de demandas que envolvam as mesmas questões de direito, como proporcionar uma decisão uniforme a estes casos, propiciando não só a economia e celeridade processuais, como a isonomia de tratamento aos casos (evitando decisões conflitantes).

Em seus arts. 988 a 999, o Projeto define o procedimento específico do incidente, que será promovido através de pedido ao Presidente do Tribunal pelo juiz ou relator (de ofício) e através de petição pelas partes, Ministério Público, Defensoria, pessoa jurídica de direito público ou associação civil cuja finalidade institucional inclua a defesa do interesse ou direito objetivo do incidente. Este será promovido especificamente quando estiver presente o "risco de ofensa à isonomia e à segurança jurídica" e houver "efetiva repetição de processos" que contenham controvérsia idêntica "sobre questão unicamente de direito".

Veja-se, pois, que se trata de hipótese de tentativa de reunião e julgamento de questão de direito idêntica tratada em diversos processos, o que sugeriria demanda única para defesa de direitos individuais homogêneos.

Tanto o espírito da norma é esse que se atribui a competência até mesmo à associação civil, que possua em sua finalidade a defesa do interesse em questão (pertinência temática). 
O juízo de admissibilidade e o julgamento do incidente competirão ao plenário do tribunal ou, onde houver, ao órgão especial.

Se admitido, o incidente causa a suspensão dos processos, sendo permitida a concessão de medidas de urgência no juízo de origem. $\mathrm{O}$ acolhimento do incidente terá efeitos apenas no âmbito de competência do tribunal prolator. Em havendo recurso, e seu mérito tendo sido apreciado pelo plenário do STF ou pela corte especial do STJ, a tese jurídica firmada será aplicada a todos os processos que versem sobre questão de direito idêntica em todo o território nacional.

Em caso de rejeição do incidente, o curso dos processos será retomado.

O incidente deve ser julgado no prazo de 1 (um) ano (art. 996). Se referido prazo for superado, as ações originais passam a tramitar normalmente, salvo decisão fundamentada do relator do incidente em sentido contrário.

Uma particularidade do procedimento é que os recursos especial e extraordinário terão efeito suspensivo, sendo presumida a repercussão geral da matéria.

Vê-se que, a princípio, a proposição trazida pelo projeto parece ser um grande benefício aos indivíduos, não só por evitar a morosidade na tramitação destes feitos (que também é causada pela grande quantidade de demandas), como representa fator de eliminação da insegurança jurídica, evitando o risco de decisões conflitantes em casos que devem receber um tratamento isonômico.

A segunda proposição trazida pelo Projeto 8.046/2010 se trata da "conversão da ação individual em coletiva" refletida no art. 334 do Projeto.

Referido dispositivo estabelece que "atendidos os pressupostos da relevância social e da dificuldade de formação do litisconsórcio, o juiz, a requerimento do Ministério Público ou Defensoria, ouvido o autor, poderá converter em coletiva a ação individual (...)". 
Ao se observar as hipóteses previstas pelo Projeto, verifica-se a intenção de proteger os interesses difusos e coletivos, nas situações em que a ofensa em análise no processo afete a esfera jurídica do indivíduo e da coletividade ou em que haja uma relação plurilateral que exija solução uniforme.

Determinada a conversão, o autor da demanda deverá aditar ou emendar a inicial e, se ocorrido o aditamento, o juiz intimará o réu para resposta em quinze dias.

No caso de ocorrência da conversão, o autor originário atuará em litisconsórcio unitário com o legitimado para a demanda coletiva.

Da análise das duas proposições trazidas pelo Projeto 8.046/2010, verifica-se não apenas a intenção do legislador de dar celeridade e efetividade ao provimento jurisdicional, como o desígnio de tratar os interesses e direitos de forma molecular, protegendo-se os direitos coletivos lato sensu.

A primeira proposição visa a atender as hipóteses de direitos individuais coletivos sedimentados em diversas demandas, resolvendo-se a questão de forma isonômica e célere. A segunda objetiva proporcionar a tutela de forma ampla, quando verificada a violação da esfera jurídica da coletividade e não apenas do indivíduo que ingressou com a demanda, protegendo os direitos coletivos e difusos. Referido sistema foi pensado para atuar de forma complementar, tanto é que é vedada a conversão da demanda individual em coletiva para tutela de direitos individuais homogêneos (art. 334, §2º $)$.

As duas inovações trazidas revelam-se plenamente compatíveis com o atual objetivo da prestação jurisdicional, qual seja, a solução efetiva dos conflitos sociais. 


\section{O rol de legitimados}

\subsection{Organização Sindical, Entidades de Classe e Associação}

O sindicato consiste em um grupo de pessoas que exercem a mesma profissão e se uniram de forma organizada com o objetivo de tutelar seus interesses, assegurando a defesa e representação da respetiva profissão. ${ }^{128}$ Os interesses envolvidos são coletivos da categoria, não se relacionando, a priori, a interesse público.

Para a lei sindical, associações profissionais são "agrupamentos de empregadores, empregados e trabalhadores autônomos ou profissionais liberais que exerçam a mesma profissão ou atividade, ou profissões ou atividades similares ou conexas"129.

Veja-se que o sindicato, em seu conceito primário, se trata de uma associação. Nesse passo, as regras a ele estabelecidas aplicam-se, em sua grande maioria, também às associações.

Paralelamente aos sindicatos e associações, mas seguindo as mesmas regras destes, no que concerne à legitimação ativa para o mandado de segurança coletivo, tem-se a entidade de classe. $\mathrm{O}$ relevo do estudo das entidades de classe se dá em relação à espécie “ordem profissional”. A principal delas é a Ordem dos Advogados do Brasil (OAB).

A ordem profissional é pessoa jurídica de direito público, que atua em favor de seus associados que a ela aderem, via de regra, de forma coativa. Os associados estão submetidos às regras e regulamentações que referida ordem emitir, a partir de seus conselhos. Na ordem profissional estão presentes os seguintes elementos: (i) conjunto de pessoas físicas; (ii) conselhos eleitos que regulamentam o ente e aplicam sanções; (iii) associação de forma coerciva; (iv) objeto específico vinculado à organização e exercício da profissão $^{130}$

\footnotetext{
${ }^{128}$ GOMES, Orlando. Curso de Direito do Trabalho, v. 2, p. 723.

${ }^{129}$ CRETELLA JR., José. Do mandado de Segurança Coletivo. Rio de Janeiro: Forense, 1999, pp. 64-66.

${ }^{130}$ Ibidem, p. 70.
} 
A legitimação dos sindicatos, entidades de classe e associações para defesa dos direitos de sua categoria e seus membros em sede de mandado de segurança coletivo está expressa nos arts. 5, LXX, "b" ${ }^{131}$ e $8^{\circ}$, III da CF ${ }^{132}$ e 21 , caput da Lei 12.016/2009 ${ }^{133}$. A tutela prevista legalmente se presta à proteção de direitos difusos, coletivos e individuais homogêneos dos integrantes da categoria ou classe (direitos líquidos e certos) contra ato de autoridade.

Consoante já narrado em capítulo anterior, embora existam autores que defendam a impossibilidade de impetração do writ coletivo para a defesa de direitos difusos, a teoria que parece mais acertada é aquela que pugna pela possibilidade da medida. Entende-se que existem direitos líquidos e certos no campo dos direitos difusos, como já referido neste trabalho, a cujos itens ora se reitera.

A leitura do dispositivo constitucional e da lei do mandado de segurança sugere que a exigência de constituição e funcionamento do ente há pelo menos 1 (um) ano aplique-se exclusivamente à associação. Entretanto, há entendimento doutrinário e jurisprudencial determinando que o sindicato e a entidade de classe também cumpram referida regra, demandando, ainda, a demonstração de pertinência temática específica relativamente à defesa de direito de seus membros.

Sobre o tema, Hermes Zaneti Jr. ${ }^{134}$ defende a distinção de tratamento em relação aos sindicatos e entidades de classe em relação às associações, especificamente no que concerne à exigência da regra de necessidade do funcionamento do ente há 1 (um) ano. Zanetti separa as duas hipóteses aduzindo que:

131 art. $5^{\circ}(\ldots)$

LXX - o mandado de segurança coletivo pode ser impetrado por:

b) organização sindical, entidade de classe ou associação legalmente constituída e em funcionamento há pelo menos um ano, em defesa dos interesses de seus membros ou associados;

132 art. $8^{\circ}(\ldots)$

III - ao sindicato cabe a defesa dos direitos e interesses coletivos ou individuais da categoria, inclusive em questões judiciais ou administrativas;

133 Art. 21. O mandado de segurança coletivo pode ser impetrado por partido político com representação no Congresso Nacional, na defesa de seus interesses legítimos relativos a seus integrantes ou à finalidade partidária, ou por organização sindical, entidade de classe ou associação legalmente constituída e em funcionamento há, pelo menos, 1 (um) ano, em defesa de direitos líquidos e certos da totalidade, ou de parte, dos seus membros ou associados, na forma dos seus estatutos e desde que pertinentes às suas finalidades, dispensada, para tanto, autorização especial.

${ }_{134}$ ZANETI JR., Hermes. Mandado de Segurança Coletivo - Aspectos Controversos, Porto Alegre: Ed. Sergio Antonio Fabris, 2001, p. 124. 
Pela simples leitura do texto depreende-se que a mens legis é garantir a atenção a requisitos mínimos para a legitimação. A primeira parte menciona os sindicatos e as entidades de classe, para o que há necessidade de obediência às formalidade legais de constituição.

Dessas constatações decorre que às entidades de classe e aos sindicatos não poderão ser exigidos os requisitos da pré-constituição e funcionamento há pelo menos um ano. Por óbvio, é necessária a prova de sua regular constituição e de seu enquadramento como sindicato ou entidade de classe.

A importância, no entanto, da regra de constituição e funcionamento das entidades por no mínimo um ano se dá exatamente porque evita a criação de situações de exceção, em que se cria uma associação ad hoc simplesmente para atuação em determinado caso, de relevo social. A manutenção da regra cria segurança para os tutelados, diminuindo o risco de que sejam criadas entidades oportunistas, conforme um caso concreto se apresente.

Por outro lado, deve-se evitar que o requisito formal prejudique a tutela dos direitos coletivos quando inexiste outra entidade que possa atuar na proteção de tal direito. Atento a tal desígnio, o STJ já decidiu sobre o tema, alegando que "presente o interesse social evidenciado pela dimensão do dano e apresentando-se como relevante o bem jurídico a ser protegido, pode o juiz dispensar o requisito da pré-constituição superior a um ano da associação autora da ação". ${ }^{135}$

Parte da doutrina assevera que a legitimação do sindicato se relaciona à "defesa dos interesses globais da categoria profissional, não se considerando individualmente nem considerando o somatório dos diversos interesses individuais, mas sim, os interesses considerados num todo, ou seja, a média dos interesses coletivos." ${ }^{136}$ Em que pese o entendimento em referência, é certo que a normatização vigente permitiu também a tutela dos interesses individuais pelos sindicatos, quer através de mecanismos individuais, quer considerados tais direitos coletivamente.

${ }^{135}$ STJ, REsp 121.067/PR, j. 17.04.2001, rel. Min. Barros Monteiro, DJU 25.06.2001.

${ }^{136}$ SZAMIAWSKI, Elimar. O Sindicato e suas relações com a justiça do trabalho, São Paulo: Ed. RT, 1986, p. 46). 
Importante mencionar, ainda, que a disposição legal contida no art. 21, caput, da Lei 12.016/2009 trouxe inovações que sedimentaram entendimentos jurisprudenciais relevantes sobre a tutela coletiva por parte dos entes em referência.

Havia grande discussão sobre a necessidade de a entidade requerer autorização do membro do grupo para sindicatos, entidades de classe e associações poderem atuar em juízo em favor deste, ainda que para a tutela de interesse coletivo. A questão foi superada no julgamento do MS 4.126/DF, DJ11.03.1996, rel. Min. Demócrito Reinaldo, em que se reconheceu a desnecessidade de autorização dos membros para impetração do mandamus. ${ }^{137}$

Tal divergência doutrinária e jurisprudencial deu causa à edição da Súmula 629 do STF: "A impetração de mandado de segurança coletivo por entidade de classe em favor dos associados independe da autorização destes”.

Outro ponto de discussão referia-se à possibilidade de referidos entes defenderem judicialmente o interesse coletivo de apenas parcela dos membros do grupo ou classe. Alguns autores defendiam que a tutela coletiva poderia ser realizada somente em relação à totalidade da classe ou grupo. Tal entendimento doutrinário e jurisprudencial ensejou a edição da Súmula 630 do STF: "A entidade de classe tem legitimação para o mandado de segurança ainda quando a pretensão veiculada interesse apenas a uma parte da respectiva categoria".

A Lei 12.016/2009, conforme mencionado supra, pacificou definitivamente o assunto, ao dispor sobre a defesa de direitos líquidos e certos "da totalidade ou de parte" dos seus membros ou associados, (...) “dispensada, para tanto, autorização especial”. Tal alteração legislativa afastou a previsão do art. 2-A, parágrafo único, da Lei 9.494/97. ${ }^{138}$

\footnotetext{
${ }^{137}$ Trecho do voto: "a constituição federal (art. 5, LXX, "b"), ao atribuir, as associações, o poder de impetrar mandado de segurança coletivo em defesa dos interesses dos seus membros, criou caso de legitimação extraordinária que se enquadra no instituto da substituição processual, porquanto, age, (a associação) em nome próprio por direito de terceiros, estando legitimada a postular em juízo o direito de que não e titular, por determinação da carta politica. a entidade associativa que impetra segurança coletiva não se coloca, no processo, como mandataria dos respectivos associados, razão por que torna-se desnecessária a previa autorização de seus membros."

${ }^{138}$ Art. 2-A (...)
} 
Verifica-se hoje, portanto, que os sindicatos, entidades de classe e associações podem impetrar mandado de segurança (individual ou coletivo) nas seguintes situações: (i) mandado de segurança individual da entidade em defesa de interesse próprio que, por obvio, não necessita de autorização (art. 5, LXIX, da CF); (ii) mandado de segurança individual para defesa de interesse específico dos membros da categoria, mediante autorização destes (denominada de representação processual - art. 5, XXI, da CF); (iii) mandado de segurança coletivo, para defesa de interesses da classe como um todo, relacionados ao escopo da entidade, havendo desnecessidade de autorização específica dos membros da classe (substituição processual - legitimação extraordinária) (art. $5^{\circ}$, LXX, da CF e art. 21 da Lei 12.016/2009).

Em que pese o entendimento sobre a possibilidade dos entes em questão impetrarem mandado de segurança individual em favor do membro da categoria, a jurisprudência não tem admitido o writ para defesa de interesse particular do associado, nem mesmo na hipótese de mera representação (art. 5, XXI, da CF). ${ }^{139}$

Nesse mesmo sentido o entendimento de Pedro Carlos Sampaio Garcia ${ }^{140}$, aduzindo que o "trabalhador, quando se cuida de interesse puramente individual, é o legitimado

Parágrafo único: Nas ações coletivas propostas contra a União, os Estados, o Distrito Federal, os Municípios e suas autarquias e fundações, a petição inicial deverá obrigatoriamente estar instruída com a ata da assembléia da entidade associativa que a autorizou, acompanhada da relação nominal dos seus associados e indicação dos respectivos endereços.

139 MANDADO DE SEGURANÇA COLETIVO. DEFESA DE INTERESSE PARTICULAR DE ASSOCIADO. DESCABIMENTO. - O MANDAMUS COLETIVO NÃO SE PRESTA A TUTELAR DIREITO INCOMPATIVEL COM OS OBJETIVOS INSTITUCIONAIS NUCLEARES DO SINDICATO IMPETRANTE. - MANDADO DE SEGURANÇA NÃO CONHECIDO. (STJ, MS 2.016/DF, rel. Min. César Rocha, DJ 11.10.1993).

e

Processo civil. Recurso especial. Ação individual proposta por associação, na qualidade de representante de um único consumidor associado, com fundamento no art. $5^{\circ}, \mathrm{XXI}$, da CF. Propositura da ação no foro do domicílio da Associação, que é diverso dos domicílios, tanto do autor da ação, como do réu. Declinação da competência promovida de ofício. Manutenção. - O permissivo contido no art. $5^{\circ}, \mathrm{XXI}$, da CF, diz respeito apenas às ações coletivas passíveis de serem propostas por associações, em defesa de seus associados. Tal norma não contempla a representação do consumidor em litígios individuais, de modo que deve ser reconhecida a ilegitimidade ativa da associação. - Não obstante a exclusão da associação do pólo ativo da relação processual, a existência de procuração passada diretamente pelo consumidor à mesma advogada da associação autoriza o aproveitamento do processo, mantendo-se, como autor da ação, apenas o consumidor. (...) Recurso especial a que se nega provimento. (STJ, REsp 1.084.036/MG, rel. Min. Nancy Andrighi, DJ 17.03.2009)

${ }^{140}$ GARCIA, Pedro Carlos Sampaio. O sindicato e o processo: a coletivização do processo do trabalho. São Paulo: Saraiva, 2002, p. 150. 
ordinário para defender esse direito em juízo, não havendo razão para que ao sindicato também seja atribuída legitimação em tal hipótese. Não há aí nenhum interesse da categoria em jogo, nenhum interesse a ser tratado de forma coletiva".

Outro ponto de discussão sobre o instituto em tela refere-se à necessidade de vinculação entre o objeto da entidade e o interesse defendido em juízo. Doutrina e jurisprudência divergem sobre a amplitude de cumprimento de tal relação, havendo autores que sustentam a flexibilização da ideia da "representação adequada".

Sobre os temas específicos da pertinência temática e da representação adequada, importante reportar-se aos capítulos anteriores existentes neste trabalho.

Sobre o ponto, Cassio Scarpinella Bueno defende uma interpretação ampla da norma (Lei 12.016/2009), sugerindo uma atuação mais flexível dos entes em referência:

O art. 21, caput, da Lei 12.016/2009 ainda exige que a atuação da organização sindical, entidade de classe ou associação seja pertinente às suas finalidades. Trata-se de sadia compreensão do que acabou sendo conhecido como pertinência temática. O objeto da impetração coletiva, no caso, deve relacionar-se com as finalidades institucionais do impetrante, razão primeira de ser do elo associativo. Não se trata, contudo, de entender a exigência restritivamente. O mandado de segurança coletivo não se limita à tutela jurisdicional de um direito exclusivo da categoria substituída processualmente, mas mais amplamente, de um direito que se relaciona com as finalidades institucionais do impetrante ${ }^{141}$

Ada Pellegrini Grinover também defende uma maior amplitude ao instituto do writ coletivo, transcendendo a ideia de classe ou categoria de indivíduos. Para a autora

a única interpretação harmoniosa da alínea b do inc. LXX do art. 5. ${ }^{\circ}$, em sintonia com o disposto quanto aos sindicatos e às entidades

${ }^{141}$ BUENO, Cássio Scarpinella. A Nova Lei do Mandado de Segurança. São Paulo: Saraiva, 2009, p. 126127. 
associativas, é que, para estes, as normas específicas cuidam de interesses coletivos da categoria, ou de direitos individuais de seus membros; enquanto a via potenciada do mandado de segurança coletivo não encontra restrições. Interesses de membros ou associados, sim, mas também interesses difusos (que transcendam à categoria), além dos coletivos e dos direitos individuais homogêneos. ${ }^{142}$

Nelson Nery Jr. vai além de Scarpinella e sugere a possibilidade dos sindicatos, entidades de classe e associações adicionarem interesses secundários em suas finalidades institucionais, que também se prestariam para fins de cumprimento da pertinência temática quando da impetração do writ. $^{143}$

No mesmo sentido Gregório Assagra de Almeida aduziu a possibilidade de inclusão de interesses secundários no estatuto do sindicato, circunstância que lhe conferiria pertinência temática para impetração de mandado de segurança em outras hipóteses além daquelas exclusivamente relacionadas à categoria ${ }^{144}$ :

\begin{abstract}
Sindicato dos empregados no setor metalúrgico pode, por óbvio, defender direitos metaindividuais do setor de metalurgia, sem qualquer outra providência formal ou de conteúdo. Mas para defender o meio ambiente, genericamente considerado, é preciso que em seus estatutos esteja prevista esta finalidade associativa. Se estiver, é vedado ao juiz examinar a conveniência de essa finalidade constar dos estatutos. O sindicato ou associação pode, perfeitamente, indicar outras finalidades institucionais secundárias, além daquelas primárias que independem de qualquer outra consideração.
\end{abstract}

${ }^{142}$ GRINOVER, Ada Pellegrini. Mandado de segurança coletivo: legitimação, objeto e coisa julgada. Revista de processo, $n^{\circ}$ 58. São Paulo: Ed. RT, 1990, p. 79.

${ }^{143}$ NERY JR., Nelson. Ação civil pública no processo do trabalho. In: MILARÉ, Édis (coord.). Ação civil pública: Lei 7.347/1985 - 15 anos, São Paulo: Ed. RT, 2001, p. 573-574.

144 ALMEIDA, Gregório Assagra. Direito processual coletivo brasileiro: um novo ramo do direito processual. São Paulo: Saraiva, 2003, p. 515/516. 
Rodolfo de Camargo Mancuso, por outro lado, defende que a atuação dos sindicatos se relaciona a questões afetas à categoria e ao meio ambiente do trabalho. ${ }^{145}$

Referido autor ensina, ainda, que "especificamente no que concerne às associações, anote-se que o interesse processual está diretamente relacionado à coincidência entre seus fins institucionais (art. 5. ${ }^{\circ}$, II, da Lei 7.347/1985) e o interesse perseguido na ação coletiva". 146

Ricardo de Barros Leonel ${ }^{147}$ perfilha do mesmo entendimento e atesta que:

Na legitimação das associações, a presunção do interesse fica mitigada de forma mais clara, pois notoriamente só poderão demandar coletivamente sobre matérias cuja proteção seja a finalidade da própria instituição, e se comprovado o preenchimento do requisito da representatividade adequada.

Celso Agrícola Barbi questiona a atuação das associações fora do escopo institucional desta, afirmando que não vislumbra "razão para que uma associação ou entidade criada com determinadas finalidades e para defesa de interesses de seus membros ou associados passe a atuar com finalidades não previstas em seus estatutos e para defender pessoas estranhas aos seus quadros"148.

Sobre o tema, há decisões do STF que entendem que o direito tutelado não precisa necessariamente estar relacionado aos fins da entidade, mas o direito protegido deve decorrer de alguma característica própria da categoria. ${ }^{149}$ ${ }^{145}$ MANCUSO, Rodolfo de Camargo. Ação civil pública em defesa do meio ambiente, do patrimônio
cultural e dos consumidores, 9. ed. São Paulo: Ed. RT, 2004, p. 197.
${ }^{146}$ Ibidem, p. 70 .
${ }^{147}$ LEONEL, Ricardo de Barros. Manual do processo coletivo. São Paulo: Revista dos Tribunais, 2002, p.
167 .
${ }^{148}$ BARBI, Celso Agricola. Do mandado de segurança, $6^{\text {a }}$ ed., Rio de Janeiro: Forense, p. 283 .
${ }^{149}$ EMENTA: CONSTITUCIONAL. PROCESSUAL CIVIL. MANDADO DE SEGURANÇA COLETIVO.
SUBSTITUIÇÃO PROCESSUAL. AUTORIZAÇÃO EXPRESSA. OBJETO A SER PROTEGIDO PELA
SEGURANÇA COLETIVA. C.F., art. $5^{\circ}$, LXX, "b". I. - A legitimação das organizações sindicais, entidades
de classe ou associações, para a segurança coletiva, é extraordinária, ocorrendo, em tal caso, substituição
processual. C.F., art. $5^{\circ}$, LXX. II. - Não se exige, tratando-se de segurança coletiva, a autorização expressa
aludida no inciso XXI do art. $5^{\circ}$ da Constituição, que contempla hipótese de representação. III. - O objeto do
mandado de segurança coletivo será um direito dos associados, independentemente de guardar vínculo com
os fins próprios da entidade impetrante do writ, exigindo-se, entretanto, que o direito esteja compreendido na 


\subsection{Partidos Políticos}

O partido político é uma instituição híbrida, de difícil conceituação, vez que possui diversas vertentes: sociológica, jurídica, econômica, política, entre outras.

Fávila Ribeiro preceitua partido político como "um grupo social de relevante amplitude destinado à arregimentação coletiva, em torno de ideias e de interesses, para levar seus membros a compartilharem do poder decisório nas instâncias governamentais". 150

Paulo Bonavides traz conceito semelhante, aduzindo que existe "partido político toda vez que uma organização de pessoas, inspiradas por ideias ou movidas por interesses, buscam tomar o poder, normalmente pelo emprego de meios legais, e nele conservar-se para a realização dos fins pugnados". 151

Trata-se, pois, de um grupo organizado, legalmente estabelecido, que possui ideologia mestra, com objetivo de ocupar cargo político.

A efetiva regulamentação dos partidos políticos ocorreu em nosso país em 1932, com a edição do Decreto-lei 21.076/32. Durante os períodos de ditadura, sua regulação não teve grandes avanços, chegando a ser extinta a normatização por determinado período.

titularidade dos associados e que exista ele em razão das atividades exercidas pelos associados, mas não se exigindo que o direito seja peculiar, próprio, da classe. IV. - R.E. conhecido e provido. (STF - RE 181.438/SP - rel.: Min. Carlos Velloso, DJ 20.09.1996)

e

CONSTITUCIONAL. PROCESSUAL CIVIL. MANDADO DE SEGURANÇA COLETIVO. SUBSTITUIÇÃO PROCESSUAL. AUTORIZAÇÃO EXPRESSA. OBJETO A SER PROTEGIDO PELA SEGURANÇA COLETIVA. C.F., art. 5º LXX, "b". I. - A legitimação das organizações sindicais, entidades de classe ou associações, para a segurança coletiva, é extraordinária, ocorrendo, em tal caso, substituição processual. C.F., art. 5, LXX. II. - Não se exige, tratando-se de segurança coletiva, a autorização expressa aludida no inciso XXI do art. $5^{\circ}$ da Constituição, que contempla hipótese de representação. III. - O objeto do mandado de segurança coletivo será um direito dos associados, independentemente de guardar vínculo com os fins próprios da entidade impetrante do writ, exigindo-se, entretanto, que o direito esteja compreendido na titularidade dos associados e que exista ele em razão das atividades exercidas pelos associados, mas não se exigindo que o direito seja peculiar, próprio, da classe. IV. - R.E. conhecido e provido. (STF - RE 193.382/SP - rel.: Min. Carlos Velloso, DJ 20.09.1996.)

${ }^{150}$ RIBEIRO, Fávila. Direito Eleitoral, Rio de Janeiro: Forense, 1976, p. 203.

${ }^{151}$ BONAVIDES, Paulo. Ciência Política, Rio de Janeiro: FGV, 1967, p. 283. 
Foi com a Constituição Federal de 1988 que o partido político tomou forma como pessoa jurídica de direito privado, enquadrando-se no perfil de associação. ${ }^{152}$

Apesar de a doutrina majoritária sobre o tema definir o partido político como ente privado, há doutrinadores, como Arnoldo Wald, que defendem sua denominação como pessoa jurídica de direito público. ${ }^{153}$

No que concerne especificamente ao tema deste trabalho, o partido político encontra divergentes interpretações quanto à amplitude de seu âmbito de atuação para fins de legitimação e proteção de direitos coletivos lato sensu em sede de mandado de segurança coletivo.

A legitimidade ativa dos partidos políticos para o writ coletivo foi definida pelo art. 5', LXX, “a”, da $\mathrm{CF}^{154}$ e art. 21, caput da Lei 12.016/2009. ${ }^{155}$

Inicialmente se diga que a Lei 12.016/09 estabeleceu ilegítima restrição à atuação dos partidos, que não estava prevista na $\mathrm{CF} / 88$. Trata-se da criação de requisito específico consistente na exigência de "defesa de seus interesses legítimos relativos a seus integrantes ou à finalidade partidária”.

Tal limitação foi criticada por grande parte da doutrina, tendo muitos autores aduzido a ineficácia da proposição em referência.

Há duas correntes doutrinárias contrapostas sobre o tema da legitimação dos partidos políticos.

\footnotetext{
${ }^{152}$ SILVA, José Afonso da Silva. Curso de Direito Constitucional Positivo, 8. a ed., São Paulo, 1992, p. 411.

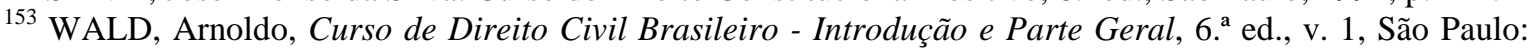
Ed. RT, 1989, p. 133.

${ }^{154} \operatorname{Art.} 5^{\circ}(\ldots)$

LXX - o mandado de segurança coletivo pode ser impetrado por:

a) partido político com representação no Congresso Nacional;

${ }_{155}$ Art. 21 . O mandado de segurança coletivo pode ser impetrado por partido político com representação no Congresso Nacional, na defesa de seus interesses legítimos relativos a seus integrantes ou à finalidade partidária, ou por organização sindical, entidade de classe ou associação legalmente constituída e em funcionamento há, pelo menos, 1 (um) ano, em defesa de direitos líquidos e certos da totalidade, ou de parte, dos seus membros ou associados, na forma dos seus estatutos e desde que pertinentes às suas finalidades, dispensada, para tanto, autorização especial.
} 
A primeira pugna por uma ampla tutela de direitos coletivos por meio do mandado de segurança, sendo abarcados por referida proteção: os direitos difusos, coletivos e individuais homogêneos.

Ada Pellegrini Grinover é adepta de tal corrente, defendendo que o partido político:

(...) está legitimado a agir para a defesa de todo e qualquer direito, seja ele de natureza eleitoral, ou não. No primeiro caso, o Partido estará defendendo seus próprios interesses institucionais, para os quais se constituiu. Agirá, a nosso ver, investido de legitimação ordinária. No segundo caso - quando, por exemplo, atuar para a defesa do ambiente, do consumidor, do contribuinte - será substituto processual, defendendo em nome próprio interesses alheios. Mas nenhum outra restrição deve sofrer quanto aos interesses e direitos: além da tutela dos direitos coletivos e individuais homogêneos, que se titularizam nas pessoas filiadas ao partido, pode o partido buscar, pela via da segurança coletiva, aquela inerente a interesses difusos, que transcendam aos seus filiados. ${ }^{156}$

Na mesma esteira a jurista Lucia do Valle Figueiredo, que também defende a ampla abrangência da tutela pelo partido político:

Tudo que transcender ao individual, pois de reflexo para toda coletividade, apresentar-se com caráter de liquidez e certeza e, ainda tiver em vista o estado democrático de direito e os direitos fundamentais traduzidos lato sensu, nas liberdades públicas, poderá ser objeto do Mandado de Segurança Coletivo interposto por Partido Político. Estão os Partidos Políticos nesta carta constitucional, como garantes da cidadania, do Estado Democrático de Direito, da

156 GRINOVER, Ada Pellegrini. Mandado de segurança coletivo: legitimação, objeto e coisa julgada. Revista de processo, no 58. São Paulo: Ed. RT, 1990, p. 78. 
separação de poderes, dos direitos fundamentais, com competência para provocar a atuação do Judiciário. ${ }^{157}$

Comunga de tal entendimento José Cretella Júnior, que assevera que o partido político "será o substituto processual, que comparecerá perante o Poder Judiciário, solicitando a cessação do ato arbitrário". ${ }^{158}$

Nelson Nery Jr. também defende que o partido político atua para proteção da legalidade objetiva, não restringindo sua atuação a seus filiados. ${ }^{159}$

Carlos Ari Sundfeld opina pela legitimação extensiva a toda a coletividade e não apenas à matéria de direito eleitoral. ${ }^{160}$

Celson Agricola Barbi defende um alargamento ainda maior do instituto, afirmando não apenas a tutela de direitos difusos, coletivos e individuais homogêneos, como "aundo o pedido for de partido político, basta a simples ilegalidade e a lesão de interesse daquele tipo, não sendo caso de estabelecer qualquer vínculo entre o interesse e os membros ou filiados do partido". 161

A segunda corrente entende pela limitação da atuação do partido político, de forma que este somente poderá tutelar direitos relacionados à sua finalidade estatutária ou aos interesses de seus filiados.

Calmon de Passos perfila-se a tal corrente ${ }^{162}$, defendendo que:

(...) nenhuma legitimação extraordinária é deferida pelo legislador de forma arbitrária ou inconsequente.” (...) sendo que "a legitimação sem

\footnotetext{
${ }^{157}$ FIGUEIREDO, Lucia do Valle. Partidos Políticos e Mandado de Segurança coletivo. Revista de Direito Público, no 95, São Paulo: Ed. RT, 1990, p. 40.

${ }^{158}$ CRETELLA JR., José, Do Mandado de Segurança Coletivo, 2. a ed., Rio de Janeiro, Forense: 1991, p. 59.

${ }^{159}$ NERY JR., Nelson. Mandado de segurança coletivo. Revista de Processo, no 57, São Paulo: Ed. RT, p. 156.

${ }^{160}$ SUNDFELD, Carlos Ari. Mandado de segurança coletivo na Constituição de 1988, Revista de Direito Público, nº 89, São Paulo: Ed. RT, p. 41.

${ }^{161}$ BARBI, Celso Agrícola. Mandado de Segurança na Constituição de 1988, v. 16. Porto Alegre: Ajuris, 1989, p. 51.

${ }^{162}$ CALMON DE PASSOS, José Joaquim. Mandado de Segurança Coletivo, Mandado de Injunção e Habeas Data - Constituição e Processo, Rio de Janeiro: Forense, 1989, p. 21.
} 
fronteiras que seja reconhecida aos partidos políticos significará o caos, além de transferir para o âmbito do Judiciário (arena inadequada) a luta política que deve ser levada a cabo em outro campo.

A posição deste jurista diverge flagrantemente dos demais, ao asseverar que o partido político somente atuaria de forma supletiva aos substitutos elencados no art. $5^{\circ}$, LXX, "b".

Hely Lopes Meirelles defende que o partido político só pode impetrar mandado de segurança coletivo para a defesa de seus próprios filiados, em questões políticas, quando autorizado pela lei e pelo estatuto, mas lhe é defeso pleitear, por exemplo, direitos dos aposentados em geral, ou dos contribuintes em matéria tributária. ${ }^{163}$

A jurisprudência sobre o tema é divergente, havendo decisões contrárias à legitimação para tutela de interesses de não filiados ao partido. ${ }^{164}$

Outro ponto de discussão refere-se à possibilidade (ou não) do partido sem representação no Congresso impetrar mandado de segurança. Em vista da expressa previsão constitucional nesse sentido, a maioria dos doutrinadores assevera a necessidade de representação no Congresso como requisito para o writ coletivo, sob pena de não conhecimento da medida.

\footnotetext{
${ }^{163}$ MEIRELLES, Hely Lopes, Mandado de segurança, 31. ed. São Paulo: Malheiros, 2008, p. 33-34.

164 PROCESSUAL - MANDADO DE SEGURANÇA COLETIVO - PARTIDO POLÍTICO ILEGITIMIDADE. Quando a constituição autoriza um partido politico a impetrar Mandado de segurança coletivo, só pode ser no sentido de defender os seus filiados e em questões politicas, ainda assim, quando Autorizado por lei ou pelo estatuto. Impossibilidade de dar a um partido politico legitimidade para vir a Juízo defender 50 milhões de aposentados, que não são, em sua totalidade, filiados ao partido e que não autorizaram o mesmo a impetrar mandado de segurança em nome deles. (STJ, MS 197 / DF, rel. min. José de Jesus Filho, DJ 20.08.1990).
}

e

CONSTITUCIONAL. PROCESSUAL CIVIL. MANDADO DE SEGURANÇA COLETIVO. LEGITIMIDADE ATIVA AD CAUSAM DE PARTIDO POLÍTICO. IMPUGNAÇÃO DE EXIGÊNCIA TRIBUTÁRIA. IPTU. 1. Uma exigência tributária configura interesse de grupo ou classe de pessoas, só podendo ser impugnada por eles próprios, de forma individual ou coletiva. Precedente: RE $n^{\circ} 213.631$, rel. Min. Ilmar Galvão, DJ 07/04/2000. 2. O partido político não está, pois, autorizado a valer-se do mandado de segurança coletivo para, substituindo todos os cidadãos na defesa de interesses individuais, impugnar majoração de tributo. 3. Recurso extraordinário conhecido e provido. (STF, RE 196184/AM, rel. min Ellen Gracie, DJ 18.02.2005). 
Adotam tal entendimento: Calmon de Passos ${ }^{165}$, Ada Pellegrini Grinover ${ }^{166}$, entre outros.

Ivan Lira de Carvalho ${ }^{167}$ e José da Silva Pacheco ${ }^{168}$ defendem corrente contrária, entendendo por uma aplicação ainda mais ampla do instituto da legitimação no caso. Afirmam, pois, que a legitimidade para representação dos filiados independeria de representação no Congresso.

Sobre o ponto, Cassio Scarpinella Bueno traz proposições especificas em relação a duas situações pontuais ${ }^{169}$.

A primeira delas se trata do caso em que o partido possuía representação no Congresso e seu único representante não consegue se reeleger. Segundo o mencionado autor, tal circunstância ensejaria a extinção do processo sem resolução do mérito, nos termos do art. 267, VI, do CPC.

Parece mais razoável a tese de que possível a impetração do writ de forma ampla, para defesa de direitos difusos, coletivos e individuais homogêneos, mas com manutenção da exigência de representação no Congresso (conforme previsão expressa constitucional).

\section{Possíveis legitimados}

O mandado de segurança coletivo representa garantia constitucional e, como tal, deve propiciar a proteção dos interesses previstos pela Carta Magna. A interpretação do rol de legitimados deve, portanto, ser ampla e conforme ao sistema protetivo dos direitos coletivos.

\footnotetext{
165 CALMON DE PASSOS, José Joaquim. Mandado de Segurança Coletivo, Mandado de Injunção e Habeas Data - Constituição e Processo, Rio de Janeiro: Forense, 1989, p. 31.

${ }_{166}$ GRINOVER, Ada Pellegrini. Mandado de segurança coletivo: legitimação, objeto e coisa julgada. Revista de processo, no 58. São Paulo: Ed. RT, 1990, p. 79.

${ }^{167}$ CARVAlHO, Ivan Lira de. O Mandado de Segurança Coletivo e os Partidos Políticos, Revista de Processo, vol. 72, São Paulo: Ed. RT, 1993, p. 75.

168 PACHECO, José da Silva. As Ações Constitucionais Típicas na Constituição de 1988, in Seleções Jurídicas - ADV/COAD, Rio de Janeiro, 1989, p. 9.

${ }^{169}$ BUENO, Carlos Scarpinella. A Nova Lei do Mandado de Segurança, São Paulo: Saraiva, 2009, p. 124.
} 
O rol previsto no art. $5^{\circ}$, LXX, da CF e art. 21, caput da Lei 12.016/2009 pode ser interpretado como exemplificativo, sendo complementado pelas previsões contidas no art. 82, do $\mathrm{CDC}^{170}$ e $5^{\circ}$ da Lei $7.347 / 85^{171}$, ao menos no que concerne à legitimação do Ministério Público e da Defensoria Pública.

O fato de o art. 21, caput, da Lei 12.016/2009 não trazer novas figuras de legitimados em relação à Constituição Federal, não impede uma interpretação sistêmica da tutela protetiva de direitos coletivos.

Sobre o ponto, há discussão doutrinária sobre o fato do rol do art. 5 $, \mathrm{LXX}, \mathrm{CF} / 88 \mathrm{e}$ art. 21, caput, da Lei 12.016/09 ser taxativo ou exemplificativo.

Hermes Zaneti Jr. defende que o rol do art. $5^{\circ}$, LXX, da CF é exaustivo no que concerne aos legitimados. ${ }^{172}$

Contrariamente a tal entendimento, considerando o arcabouço legislativo sobre o tema, parece bastante razoável se defender que o rol de legitimados é exemplificativo.

Exatamente nesse sentido, são trazidas algumas hipóteses não previstas em lei em que se verifica a possibilidade de legitimação.

\footnotetext{
${ }^{170}$ Art. 82. Para os fins do art. 81, parágrafo único, são legitimados concorrentemente:

I - o Ministério Público,

II - a União, os Estados, os Municípios e o Distrito Federal;

III - as entidades e órgãos da Administração Pública, direta ou indireta, ainda que sem personalidade jurídica, especificamente destinados à defesa dos interesses e direitos protegidos por este código;

IV - as associações legalmente constituídas há pelo menos um ano e que incluam entre seus fins institucionais a defesa dos interesses e direitos protegidos por este código, dispensada a autorização assemblear.

${ }^{171}$ Art. $5^{\circ}$ Têm legitimidade para propor a ação principal e a ação cautelar:

I - o Ministério Público;

II - a Defensoria Pública;

III - a União, os Estados, o Distrito Federal e os Municípios;

IV - a autarquia, empresa pública, fundação ou sociedade de economia mista;

V - a associação que, concomitantemente:

a) esteja constituída há pelo menos 1 (um) ano nos termos da lei civil;

b) inclua, entre suas finalidades institucionais, a proteção ao meio ambiente, ao consumidor, à ordem econômica, à livre concorrência ou ao patrimônio artístico, estético, histórico, turístico e paisagístico.

${ }^{172}$ ZANETI JR., Hermes. Mandado de Segurança Coletivo - Aspectos Controversos, Porto Alegre: Ed. Sergio Antonio Fabris, 2001, p. 95.
} 


\subsection{Ministério Público}

O Ministério Público é o principal legitimado para a tutela de interesses coletivos lato sensu. As grandes demandas protetivas de direitos da coletividade são, via de regra, ajuizadas pelo Parquet.

No que concerne especificamente ao mandado de segurança coletivo, embora haja divergência doutrinária sobre o assunto, entende-se pela legitimidade do MP para impetração da medida.

Cassio Scarpinella Bueno, ao tratar da legitimidade do MP para impetração do writ coletivo assevera que:

O silêncio do art. 21, caput, da Lei 12.016/2009 não afasta a legitimidade ativa do Ministério Público para a impetração do mandado de segurança coletivo. Ela, embora não seja prevista expressamente pelo inc. LXX do art. 5. ${ }^{\circ}$ da CF/1988, decorre imediatamente das finalidades institucionais daquele órgão tais quais definidas pelos arts. 127 e 129, III, da mesma Carta e, infra constitucionalmente, pelo art. $6^{\circ}{ }^{\circ}$ VI, da LC 75/1993, para o Ministério Público da União, e no art. 32, I, da Lei 8.625/1993, para o Ministério Público dos Estados ${ }^{173}$

No mesmo sentido Eduardo de Arruda Alvim, atestando que a atuação do MP ocorre sempre que "o direito líquido e certo lesado, diga com os interesses da própria instituição ou desde que o direito líquido e certo atine com interesses daqueles a quem incumbe ao Ministério Público postular em defesa". ${ }^{174}$

Para fins de verificação da legitimação do MP, importante verificar na carta magna o escopo de atuação do parquet para fins de tutela dos direitos transindividuais.

\footnotetext{
173 BUENO, Cassio Scarpinella. A nova lei do mandado de segurança. São Paulo: Saraiva, 2009, p. 127.

${ }^{174}$ ARRUDA ALVIM, Eduardo. Mandado de segurança no direito tributário. São Paulo: Ed. RT, 1998, p. $57-58$
} 
$\mathrm{O}$ art. 127, caput, da CF estabelece que o MP atuará para a "defesa da ordem jurídica, do regime democrático e dos interesses sociais e individuais indisponíveis". Nessa linha, o art. 129, incisos III e IX, da CF prevê como funções institucionais do MP: "III promover o inquérito civil e a ação civil pública, para a proteção do patrimônio público e social, do meio ambiente $e$ de outros interesses difusos e coletivos;" (...) "IX - exercer outras funções que lhe forem conferidas, desde que compatíveis com sua finalidade, sendolhe vedada a representação judicial e a consultoria jurídica de entidades públicas" (grifouse).

Referidas disposições normativas são o cerne para definição e discussão acerca da abrangência da legitimidade do Ministério Público em sede de ação coletiva e principalmente de mandado de segurança coletivo.

Os autores que defendem a impossibilidade de impetração do writ coletivo pelo MP entendem pela inocorrência de conexão entre o art. $5^{\circ}$, LXX, da $\mathrm{CF}$ e os dispositivos constitucionais supramencionados. Não parece, porém, razoável que, num sistema de ampla proteção de direitos e interesses coletivos, estabelecidos como garantias constitucionais, não haja um tratamento isonômico das situações, observando-se o sistema como uma unidade.

Além da proteção constitucionalmente estabelecida, o CDC, em seu art. 83, expressamente dispõe que "para a defesa dos direitos e interesses protegidos" (...) "são admissíveis todas as espécies de ações capazes de propiciar sua adequada e efetiva tutela", circunstância que corrobora a hermenêutica unitária das normas protetivas de direitos coletivos.

Sobre o tema, Luís Roberto Barroso ${ }^{175}$ ensina que

(...) é precisamente por existir pluralidade de concepções que se torna imprescindível a unidade na interpretação. Afinal, a Constituição não é um conjunto de normas justapostas, mas um sistema normativo fundado em determinadas ideias que configuram um núcleo

${ }^{175}$ BARROSO, Luís Roberto. Interpretação e aplicação da constituição: fundamentos de uma dogmática constitucional transformadora. $6^{a}$ ed., São Paulo: Saraiva, 2004, p. 196. 
irredutível, condicionante da inteligência de qualquer de suas partes. O princípio da unidade é uma especificação da interpretação sistemática, e impõe ao intérprete o dever de harmonizar as tensões e contradições entre normas.

Sobre o ponto, o STJ já proferiu decisões atestando a unidade do sistema protetivo e legitimidade do MP para impetração do mandado coletivo:

AÇÃO CIVIL PÚBLICA. LEGITIMIDADE. MINISTÉRIO PÚBLICO. LESÃO À MORALIDADE PÚBLICA. 1. O Ministério público, por força do art. 129, III, da CF/88, é legitimado a promover qualquer espécie de ação na defesa do patrimônio público social, não se limitando à ação de reparação de danos. Destarte, nas hipóteses em que não atua na condição de autor, deve intervir como custos legis (LACP, art. $5^{\circ}, \S 1^{\circ}$; CDC, art. 92; ECA, art. 202 e LAP, art. $9^{\circ}$ ). 2. A carta de 1988, ao evidenciar a importância da cidadania no controle dos atos da administração, com a eleição dos valores imateriais do art. 37 da CF como tuteláveis judicialmente, coadjuvados por uma série de instrumentos processuais de defesa dos interesses transindividuais, criou um microsistema de tutela de interesses difusos referentes à probidade da administração pública, nele encartando-se a Ação Popular, a Ação Civil Pública e o Mandado de Segurança Coletivo, como instrumentos concorrentes na defesa desses direitos eclipsados por cláusulas pétreas. 3. Em consequência, legitima-se o Ministério Público a toda e qualquer demanda que vise à defesa do patrimônio público sob o ângulo material (perdas e danos) ou imaterial (lesão à moralidade). 4. A nova ordem constitucional erigiu um autêntico 'concurso de ações' entre os instrumentos de tutela dos interesses transindividuais e, a fortiori, legitimou o Ministério Público para o manejo dos mesmos. 5. A lógica jurídica sugere que legitimar-se o Ministério Público como o mais perfeito órgão intermediário entre o Estado e a sociedade para todas as demandas transindividuais e interditar-lhe a iniciativa da Ação Popular, revela contraditio in terminis. 6. Interpretação histórica justifica a posição do MP como legitimado subsidiário do autor na Ação Popular quando desistente o 
cidadão, porquanto à época de sua edição, valorizava-se o parquet como guardião da lei, entrevendo-se conflitante a posição de parte e de custos legis. 7. Hodiernamente, após a constatação da importância e dos inconvenientes da legitimação isolada do cidadão, não há mais lugar para o veto da legitimatio ad causam do MP para a Ação Popular, a Ação Civil Pública ou o Mandado de Segurança coletivo. 8. Os interesses mencionados na LACP acaso se encontrem sob iminência de lesão por ato abusivo da autoridade podem ser tutelados pelo mandamus coletivo. 9. No mesmo sentido, se a lesividade ou a ilegalidade do ato administrativo atingem o interesse difuso, passível é a propositura da Ação Civil Pública fazendo as vezes de uma Ação Popular multilegitimária. 10. As modernas leis de tutela dos interesses difusos completam a definição dos interesses que protegem. Assim é que a LAP define o patrimônio e a LACP dilargou-o, abarcando áreas antes deixadas ao desabrigo, como o patrimônio histórico, estético, moral, etc. 11. A moralidade administrativa e seus desvios, com consequências patrimoniais para o erário público enquadram-se na categoria dos interesses difusos, habilitando o Ministério Público a demandar em juízo acerca dos mesmos. 12. Recurso especial desprovido. (REsp 427.140/RO, rel. Min. José Delgado, DJ 25.08.2003)

Apesar de ser o principal ente que promove demandas na defesa de interesses coletivos, sua atuação tem sido limitada quando foge ao escopo da entidade, especialmente quando o caso envolve direitos individuais homogêneos.

A Lei Orgânica do Ministério Público (Lei 8.625/1993) estabelece especificamente em seu art. 25, IV, “a”, acerca da tutela dos direitos individuais indisponíveis e homogêneos ${ }^{176}$.

\footnotetext{
${ }^{176}$ Art. 25. Além das funções previstas nas Constituições Federal e Estadual, na Lei Orgânica e em outras leis, incumbe, ainda, ao Ministério Público:

IV - promover o inquérito civil e a ação civil pública, na forma da lei:

a) para a proteção, prevenção e reparação dos danos causados ao meio ambiente, ao consumidor, aos bens e direitos de valor artístico, estético, histórico, turístico e paisagístico, e a outros interesses difusos, coletivos e individuais indisponíveis e homogêneos;
} 
Ocorre que, em vista de tais direitos serem privados, individuais e divisíveis, muitas vezes sua proteção em demanda promovida pelo MP é tolhida pelos Tribunais, principalmente quando os direitos não apresentam aspecto de relevância social.

Sobre o tema, Rodolfo de Camargo Mancuso $^{177}$ defende a possibilidade de limitação ao âmbito de atuação do parquet, quando este não se relacionar ao interesse social:

No tocante ao MP, a restrição possível (e até óbvia) que se lhe pode fazer quanto à sua legitimação é quando se trate de um conjunto de interesses individuais puros, ou seja de mera "soma" de interesses individuais, sem nenhuma conotação de "indisponibilidade" e de "interesse social” (art. 127, CF/1988 (LGL1198813)), porque aí não haveria como sustentar que tal tutela se compatibilizaria com a natureza das funções complementares do Parquet (CF/1988 (LGL\1988\3), art. 129, IX). Aliás, a mera "soma" de interesses individuais (por exemplo, de moradores num condomínio horizontal em litígio com a Municipalidade) se resolve em litisconsórcio ativo facultativo, cabendo sua representação judicial a advogado (CPC (LGL\1973\5), arts. 37 e 46).

No ponto, precisa a lição de Kazuo Watanabe, que defende a tutela dos direitos individuais homogêneos pelo MP:

Certamente, como bem adverte Andrea Proto Pisani, não se deve restringir a legitimação para agir do MP apenas aos casos em que esteja presente o interesse geral e indiferenciado de natureza publicista, incumbindo-lhe também tutela dos interesses coletivos específicos de natureza privatística. Mas não se pode ir ao extremo de permitir que o MP tutele interesses genuinamente privados sem qualquer relevância social (como os de condôminos de um edifício de apartamentos contra o síndico ou contra terceiros ou os de um grupo

${ }^{177}$ MANCUSO, Rodolfo de Camargo. Interesses Difusos e Coletivos, Revista de Direito do Consumidor, vol. 22, Abr / 1997, p. 36. 
de uma sociedade contra outro grupo da mesma sociedade, a menos que esteja presente, por alguma razão específica, o interesse social), sob pena de amesquinhamento da relevância institucional do Parquet, que deve estar vocacionado, por definição constitucional, à defesa 'da ordem jurídica, do regime democrático e dos interesses sociais e individuais indisponíveis' (art. 127, CF/1988 (LGL1198813))”.

É nesse sentido, inclusive, a Súmula de Entendimento $n^{\circ} 7$ do Ministério Público do Estado de São Paulo:

O MP está legitimado à defesa de interesses individuais homogêneos que tenham expressão para a coletividade, como: a) os que digam respeito à saúde ou à segurança das pessoas, ou ao acesso das crianças e adolescentes à educação, b) aqueles em que haja extraordinária dispersão dos lesados; c) quando convenha à coletividade o zelo pelo funcionamento de um sistema econômico, social ou jurídico.

O que se percebe é que a atuação do MP deve ser pautada em sua função precípua, de defesa do interesse social, e não de alguns poucos indivíduos com interesses eminentemente privados.

É exatamente nesse sentido o entendimento de Hugo Nigro Mazzilli, que exemplifica situações em que não parece razoável a intervenção do MP:

Uma coisa seria pôr o MP em defesa de interesses de, digamos, meia dúzia de consumidores que tiveram seus carros danificados pela maresia, durante sua importação. Nesse caso, não haveria expressão social para justificar a atuação ministerial. Coisa diversa, porém, seria negar a priori a possibilidade da iniciativa ministerial para propor, por exemplo, uma ação coletiva que visasse a impedir o inconstitucional bloqueio de cruzados em todo o país (Plano Collor), ou a obter a devolução de tributos ilegalmente retidos ou recolhidos de milhares ou milhões de contribuintes. Nesses últimos casos, negar o interesse da sociedade como um todo na solução desses litígios e exigir que cada 
lesado comparecesse a juízo em defesa de seus interesses individuais, seria negar os fundamentos e os objetivos da ação coletiva ou da ação civil pública. ${ }^{178}$

Importante analisar, também, alguns julgados do STJ em causas em que o MP foi autor da demanda coletiva.

O primeiro caso avaliado envolve a discussão acerca da legitimidade do Ministério Público para defender direitos individuais homogêneos disponíveis. O STJ entendeu que carece de legitimidade ao MP a propositura de demanda envolvendo interesses individuais disponíveis. ${ }^{179}$

Vê-se, claramente que, quando se trata de direito disponível, cuja tutela é eminentemente privada, não cabe a intervenção do MP.

No mesmo sentido o entendimento do STJ nos casos em que há uma quantidade ínfima de consumidores a ser protegida e os interesses em análise são exclusivamente privados, sem relevância social.

Em caso em que o MP defendia os associados de um clube, com vistas a "protegêlos" de alterações ocorridas em estatuto do clube, o STJ decidiu que a legitimação não era possível, vez que defenderia pequena grupo isolado, não se relacionando a interesse da sociedade (escopo funcional do MP) ${ }^{180}$.

\footnotetext{
${ }^{178}$ MAZZILLI, Hugo Nigro. A defesa dos interesses difusos em juízo: meio ambiente, consumidor e patrimônio cultural, patrimônio público e outros interesses. $24^{a}$ ed. São Paulo: Saraiva, 2011. p. 40. 179 "AGRAVO REGIMENTAL. RECURSO ESPECIAL. PROCESSUAL CIVIL. AÇÃO CIVIL PÚBLICA. MINISTÉRIO PÚBLICO. LEGITIMIDADE ATIVA AD CAUSAM. AUSÊNCIA. DPVAT. DIREITOS INDIVIDUAIS DISPONÍVEIS. SÚMULA N. 470 DO STJ. 1. O Ministério Público carece de legitimidade para, em substituição às vítimas de acidentes, pleitear o ressarcimento de indenizações devidas pelo sistema do Seguro Obrigatório de Danos Pessoais - DPVAT, pagas a menor. Incidência da súmula 470/STJ. 2. Direitos individuais identificáveis e disponíveis, cuja defesa é própria da advocacia privada. 3. AGRAVO REGIMENTAL DESPROVIDO."

(AgRg no REsp 1129675 / GO, rel. min. PAULO DE TARSO SANSEVERINO, DJe 24/02/2012)

180 AÇÃO CIVIL PÚBLICA. RECURSO ESPECIAL. ARTIGO 535 DO CPC. VIOLAÇÃO NÃO CONFIGURADA. DISSÍDIO JURISPRUDENCIAL NÃO DEMONSTRADO. DEFESA DE INTERESSES PREDOMINANTEMENTE INDIVIDUAIS. INEXISTÊNCIA DE INTERESSES INDIVIDUAIS HOMOGÊNEOS. ILEGITIMIDADE DO MINISTÉRIO PÚBLICO. RECURSO ESPECIAL PROVIDO. 1. Não há violação ao artigo 535 do CPC quando a Corte de origem aprecia a questão de maneira fundamentada, apenas não adotando a tese do recorrente. 2. O descumprimento das exigências contidas nos
} 
Situação análoga ocorreu quando o MP pretendeu tutelar em juízo direitos patrimoniais de adquirentes de unidades de conjunto habitacional. Nesse caso, o STJ asseverou que o MP não pode realizar a "proteção individual, pessoal, particular, de grupo isolado, mas a defesa coletiva dos consumidores, considerada em sua dimensão comunitária". 181

Por fim, importante observar o STJ têm reconhecido expressamente a ilegitimidade do MP quando inexistente interesse social relevante compatível com a finalidade da instituição $^{182}$.

Da análise dos casos, se denota que o STJ tem se valido do espírito do instituto da representação adequada e pertinência temática, para limitar a atuação do MP, nos casos em que os interesses envolvidos não se coadunam com a finalidade social da entidade.

artigos 541, parágrafo único, do CPC e $255, \S 1^{\circ}$ e $2^{\circ}$, do RISTJ impede o conhecimento do recurso especial pela alínea "c" do permissivo constitucional. 3. O Ministério Público não tem legitimidade ativa para propor ação civil pública na qual busca a suposta defesa de um pequeno grupo de pessoas - no caso, dos associados de um clube, numa óptica predominantemente individual. 4. A proteção a um grupo isolado de pessoas, ainda que consumidores, não se confunde com a defesa coletiva de seus interesses. Esta, ao contrário da primeira, é sempre impessoal e tem como objetivo beneficiar a sociedade em sentido amplo. Desse modo, não se aplica à hipótese o disposto nos artigos 81 e 82, I, do CDC. 5. No caso, descabe cogitar, até mesmo, de interesses individuais homogêneos, isso porque a pleiteada proclamação da nulidade beneficiaria esse pequeno grupo de associados de maneira igual. Além disso, para a proteção dos interesses individuais homogêneos, seria imprescindível a relevância social, o que não está configurada na espécie. 6. Recurso especial provido.

(REsp 1109335 / SE, rel min. LUIS FELIPE SALOMÃO, DJe 01/08/2011)

${ }^{181}$ AGRAVO REGIMENTAL - RECURSO ESPECIAL - AÇÃO CIVIL PÚBLICA - MINISTÉRIO PÚBLICO - PREQUESTIONAMENTO - AUSÊNCIA - LEGITIMIDADE ATIVA - SUBSTITUIÇÃO PROCESSUAL - DIREITO DO CONSUMIDOR - DEFESA - PARCELA ÍNFIMA DE CONSUMIDORES - DIREITO INDIVIDUAL HOMOGÊNEO NÃO CARACTERIZADO - DECISÃO AGRAVADA MANTIDA - IMPROVIMENTO. I. É inadmissível o Recurso Especial quanto às questões que não foram apreciadas pelo Tribunal de origem, incidindo, à espécie, o óbice da Súmula 211/STJ. II - A atuação do Ministério Público como substituto processual na defesa de direitos decorrentes de relação de consumo, é legítima apenas quando balizada pelo trato impessoal e coletivo dos direitos subjetivos lesados. Não compete ao Parquet a proteção individual, pessoal, particular, de grupo isolado, mas a defesa coletiva dos consumidores, considerada em sua dimensão comunitária e, portanto, impessoal, objetivando o cumprimento da lei em benefício da sociedade como um todo. III - A pretensão formulada não pode ser considerada hipótese de direitos individuais homogêneos, uma vez que não há interesse coletivo relevante a ser tutelado diante da insurgência de parcela mínima dos adquirentes de unidades do conjunto habitacional. Agravo Regimental improvido.

(AgRg no REsp 710.337 - SP, rel. min. SIDNEI BENETI, DJe 18/12/2009)

${ }_{182}$ PROCESSUAL CIVIL. AÇÃO CIVIL PÚBLICA. LEGITIMIDADE. MINISTÉRIO PÚBLICO. INTERESSES INDIVIDUAIS HOMOGÊNEOS. O Ministério Público não tem legitimidade para propor ação civil pública na defesa de interesses individuais homogêneos, quando inexistente relevante interesse social compatível com a finalidade da instituição. Recurso especial conhecido e não provido. (REsp 613493 / DF, rel. min. CESAR ASFOR ROCHA, DJ 20/03/2006 p. 281) 
No que concerne especificamente ao mandado de segurança coletivo, o MP está perfeitamente legitimado para atuação em juízo, exatamente por conta de sua função institucional, de tutela dos interesses transindividuais.

O MP seria, também, legitimado subsidiário em mandado de segurança coletivo no caso de partido que perdeu a representatividade no Congresso.

As limitações à atuação do parquet em mandado de segurança seriam análogas às situações narradas supra (interesses indisponíveis, defesa de interesse social, entre outros).

\subsection{Defensoria Pública}

A Defensoria Pública é definida pela Constituição Federal, em seu art. 134, como a "instituição essencial à função jurisdicional do Estado", incumbida da "orientação jurídica e a defesa, em todos os graus, dos necessitados, na forma do art. $5^{\circ}$, LXXIV”.

Além da defesa dos hipossuficientes, a Defensoria possui função precípua concernente à promoção da inclusão social, cultural e jurídica de referida classe de indivíduos.

Apesar da legitimidade da Defensoria Pública para promoção de ações coletivas estar expressa no art. 5º inciso II da Lei 7.347/85 (com redação dada pela Lei 11.488/07), há relevante discussão judicial sobre a efetiva legitimidade desta para tutela de interesses difusos, coletivos e individuais homogêneos em juízo.

A discussão se exaspera quando se trata do mandado de segurança coletivo, vez que, assim como no caso do Ministério Público, a Defensoria não está prevista no rol de legitimados.

Para atendimento de tal anseio, é fundamental identificar a relação da Defensoria Pública com a defesa de direitos transindividuais, como pressuposto fundamental para legitimação ativa no writ. 
Indubitavelmente referido ente tem papel importante na tutela de direitos coletivos e transindividuais dos necessitados, porém, a questão que se coloca é se tal desígnio é suficiente para sua legitimação ativa.

A Lei Complementar 80/1994, com redação dada pela Lei Complementar 132/2009 define expressamente as funções institucionais da Defensoria, sendo as mais importantes: "I - prestar orientação jurídica e exercer a defesa dos necessitados, em todos os graus;" (...) "VII - promover ação civil pública e todas as espécies de ações capazes de propiciar a adequada tutela dos direitos difusos, coletivos ou individuais homogêneos quando o resultado da demanda puder beneficiar grupo de pessoas hipossuficientes; VIII - exercer a defesa dos direitos e interesses individuais, difusos, coletivos e individuais homogêneos e dos direitos do consumidor, na forma do inciso LXXIV do art. $5^{\circ}$ da CF"; (...) "X promover a mais ampla defesa dos direitos fundamentais dos necessitados, abrangendo seus direitos individuais, coletivos, sociais, econômicos, culturais e ambientais, sendo admissíveis todas as espécies de ações capazes de propiciar sua adequada e efetiva tutela”.

A Lei Complementar estadual $n^{\circ}$ 988/2006, que trata da Defensoria no estado de São Paulo, define como atribuições do órgão: “art. $5^{\circ}$ (...); VI - promover: (...) c) a tutela individual e coletiva dos interesses e direitos da criança e do adolescente, do idoso, das pessoas com necessidades especiais e das minorias submetidas a tratamento discriminatório."

A atuação da Defensoria ocorre, pois, da convergência de diversos princípios e valores legalmente estatuídos, sendo que o instrumental processual coletivo se coaduna com o cumprimento das funções de referido ente.

Nada obstante tais circunstâncias, a legitimação da Defensoria para a tutela coletiva é polêmica, principalmente pelo argumento de que o objeto funcional de referido ente seria limitado à proteção de hipossuficientes.

Ocorre que, na atualidade, notoriamente se reconhece que a "necessidade" tutelada pela Defensoria não é exclusivamente econômica, abarcando, pois, também exigência de uma prestação jurisdicional efetiva. 
Sobre o tema, importante trazer o entendimento de Hermes Zaneti Jr., exaltando a legitimação atribuída à Defensoria Pública como:

(...) uma feliz novidade no processo coletivo. Apesar de já poder atuar em processos coletivos no mínimo em duas situações: (c1) advogando os interesses das associações carentes, por representação judicial; (c2) através dos órgãos especiais, constituídos para tutela dos direitos coletivos lato sensu (art. 82, III, do CDC c/c o art. 21 da Lei 7.347/1985), a extensão da legitimidade ope legis da Defensoria se insere em um quadro de valorização da nobre função essencial exercida pela instituição, sendo importante passo na consolidação dos objetivos do direito processual coletivo (...). ${ }^{183}$

A discussão sobre a legitimação da Defensoria Pública nas demandas coletivas esbarra em uma questão fundamental: ao que parece, pelo menos parte do grupo que ela pretenda tutelar judicialmente deverá ser de hipossuficientes.

Sobre o ponto, há três entendimentos possíveis: (i) absoluta falta de legitimidade da Defensoria (que já fora suscitada pelo próprio MP); (ii) legitimação condicionada à pertinência temática (ao menos parcela dos envolvidos devem ser necessitados) e; (iii) legitimação irrestrita, nos moldes do Ministério Público, no entanto com escopo diverso, qual seja, a tutela de questões de isonomia: questões raciais, de desigualdade social, entre outras.

No que concerne especificamente à legitimidade da Defensoria para a tutela de interesses coletivos, a Associação Nacional dos Membros do Ministério Público (CONAMP) ajuizou ações declaratórias específicas contestando a legitimidade da Defensoria Pública. Uma delas é de âmbito nacional (ADI 3943), sendo que existem outras, como a ADI 4452, em que se questiona a Lei Orgânica das Defensorias Estaduais (neste caso, em particular, refere-se à Defensoria de Sergipe).

${ }^{183}$ ZANETI JR., Hermes. A efetividade do mandado de segurança coletivo no Código Brasileiro de Processos Coletivos. In: Grinover, Ada Pellegrini; Mendes, Aluisio Gonçalves de Castro; Watanabe, Kazuo. Direito processual coletivo e o Anteprojeto de Código Brasileiro de Processos Coletivos. São Paulo: Ed. RT, 2007. p. 401. 
Em referidas demandas, a Conamp defende que, consoante disposto nos arts. $5^{\circ}$, LXXIV e 134, da CF, a Defensoria teria atuação limitada aos casos que envolvem pessoas necessitadas. Como o requisito para a atuação desta seria a comprovação da insuficiência de recursos pelo representado, o que seria inviabilizado no caso de defesa de interesses difusos, coletivos e individuais homogêneos.

O MP assevera que, principalmente no caso dos interesses difusos, por se tratar da proteção de sujeitos indetermináveis, não seria possível imaginar a tutela pela Defensoria, vez que jamais se conseguiria identificar quem seria ou não hipossuficiente, daqueles representados em juízo.

Contrariamente ao entendimento do MP, a professora Ada Pellegrini Grinover ofereceu parecer, a pedido da Associação Nacional dos Defensores Públicos ${ }^{184}$.

A i. jurista defende, de início, que a Constituição Federal prevê expressamente que a legitimação do MP para tutela de direitos coletivos não exclui a legitimação de terceiros, conforme disposto no art. $129, \S^{\circ}{ }^{185}$

Não bastasse tal circunstância, ela assevera que a amplitude de legitimados é fundamental para se concretizar o acesso à Justiça. Acrescenta, ainda, que o art. $134 \mathrm{CF}$ não limita a atuação da Defensoria aos casos envolvendo hipossuficientes, sendo que suas funções podem ser ampliadas, como ocorreu, por ex., no caso da curadoria especial aos não necessitados, que é hoje por ela exercida.

E, mais, assevera-se que existem necessitados que não o são na acepção econômica do termo, mas que possuem insuficiência de recursos organizacionais, culturais ou sociais. Um exemplo disto seriam os usuários de serviços públicos, de planos de saúde, entre outros.

\footnotetext{
${ }^{184}$ GRINOVER, Ada Pellegrini, Legitimidade da Defensoria Pública para Ação Civil Pública, Revista de Processo, vol. 165, Nov / 2008, p. 299.

${ }^{185}$ Art. 129 (...)§ $1^{\circ}$ - A legitimação do Ministério Público para as ações civis previstas neste artigo não impede a de terceiros, nas mesmas hipóteses, segundo o disposto nesta Constituição e na lei.
} 
O parecer retoma ainda o entendimento já consagrado pela jurisprudência de que, a legitimidade da Defensoria já era exercida antes mesmo da alteração legislativa (Lei 11.488/07), nos termos do art. 82, III $^{186}$ do CDC.

Parece equivocada a interpretação legal pretendida pelo Ministério Público. Não há dúvida que a Defensoria atua diariamente no interesse dos consumidores e de determinados indivíduos em sede de tutela coletiva, por conta da hipossuficiência organizacional destes (e não necessariamente econômica).

Nesse sentido, Araken de Assis proferiu voto atentando que "a Defensoria Pública tem legitimidade, a teor do art. 82, III, da Lei 8.078/90 (Cód. de Defesa do Consumidor), para propor ação coletiva visando à defesa dos interesses difusos, coletivos e individuais homogêneos dos consumidores necessitados." "187

Importante mencionar, por fim, que o STJ tem decidido também nesse sentido, ao reconhecer a legitimidade da Defensoria para tutela de interesses coletivos. ${ }^{188}$

186 Art. 82 (...) III - as entidades e órgãos da Administração Pública, direta ou indireta, ainda que sem personalidade jurídica, especificamente destinados à defesa dos interesses e direitos protegidos por este código;

${ }^{187}$ PROCESSUAL CIVIL. AÇÃO CIVIL PÚBLICA. INTERESSE COLETIVO DOS CONSUMIDORES. LEGITIMIDADE ATIVA DA DEFENSORIA PÚBLICA. 1. A Defensoria Pública tem legitimidade, a teor do art. 82, III, da Lei 8.078/90 (Cód. de Defesa do Consumidor), para propor ação coletiva visando à defesa dos interesses difusos, coletivos e individuais homogêneos dos consumidores necessitados. A disposição legal não exige que o órgão da Administração Pública tenha atribuição exclusiva para promover a defesa do consumidor, mas específica, e o art. $4 .^{\circ}$, XI, da LC 80/94, bem como o art. 3. ${ }^{\circ}$, parágrafo único, da LC 11.795/02-RS, estabelecem como dever institucional da Defensoria Pública a defesa dos consumidores. 2. APELAÇÃO PROVIDA

(TJRS, acórdão 70014404784/2006, J: 12.4.2006)

188 PROCESSUAL CIVIL. AÇÃO COLETIVA. DEFENSORIA PÚBLICA. LEGITIMIDADE ATIVA. ART. 5º, II, DA LEI N ${ }^{\circ}$ 7.347/1985 (REDAÇÃO DA LEI No 11.448/2007). PRECEDENTE. 1. Recursos especiais contra acórdão que entendeu pela legitimidade ativa da Defensoria Pública para propor ação civil coletiva de interesse coletivo dos consumidores. 2. Esta Superior Tribunal de Justiça vem-se posicionando no sentido de que, nos termos do art. 5º, II, da Lei $n^{\circ} 7.347 / 85$ (com a redação dada pela Lei $n^{\circ} 11.448 / 07$ ), a Defensoria Pública tem legitimidade para propor a ação principal e a ação cautelar em ações civis coletivas que buscam auferir responsabilidade por danos causados ao meio-ambiente, ao consumidor, a bens e direitos de valor artístico, estético, histórico, turístico e paisagístico e dá outras providências. 3. Recursos especiais não-providos.

(REsp 912849 / RS, rel. min. JOSÉ DELGADO, DJe 28/04/2008) 


\section{A Atividade dos legitimados}

É de extrema importância para o presente trabalho analisar que, nada obstante a relevante contribuição da doutrina quanto ao rol de legitimados para demandas coletivas e delimitação do seu campo de atuação, tal circunstância não tem impedido uma enxurrada de ações individuais versando sobre os mesmos temas das ações coletivas.

Com isto, a própria atuação dos legitimados é prejudicada e desprestigiada, não surtindo o efeito prático correspondente: representar efetivamente os interessados e evitar uma grande quantidade de demandas envolvendo os mesmos interesses (resguardando a possibilidade de ocorrência decisões conflitantes).

As duas proposições do PL 8.046/2010 (incidente de coletivização de demandas e conversão de demanda individual em coletiva), referidas em capítulo anterior, pretendem solucionar tal problema. Enquanto não vigentes tais disposições, os tribunais pátrios têm tentado dirimir o problema, com soluções interpretativas que muitas vezes ultrapassam o conteúdo do texto legalmente estabelecido.

A análise dos dois casos infra é fundamental para verificar que a jurisprudência se ateve a tal problemática e tem atuado para evitar a sua propagação.

\subsection{Caso da tarifa de assinatura residencial}

Principalmente a partir do ano de 2004, teve início um grande movimento de ajuizamento de ações individuais e coletivas para contestação da cobrança, pelas concessionárias, da tarifa de assinatura básica nos serviços de telefonia fixa.

Em São Paulo, existiram cerca de 25 (vinte e cinco) demandas coletivas tratando da matéria, sendo que a primeira delas foi ajuizada pelo IDEC contra a Telesp. Havia, ainda, por volta de 100.000 (cem mil) ações individuais sobre o tema.

Em vista de tal circunstância e da grande discussão processual sobre a participação ou não da ANATEL nas demandas (o que deslocava a competência para a justiça federal), 
o Ministério Público Federal suscitou o conflito de competência no 47.731 (CC 47.731) perante o STJ, bem como a ANADEC suscitou o conflito de competência $\mathrm{n}^{\circ} 48.177$ (CC 48.177) também perante o STJ.

A liminar foi concedida no CC 47.731 e serviu de molde para a decisão proferida no CC 48.177. Foram sobrestadas as demandas coletivas, definindo-se o juízo da $2^{\mathrm{a}}$ Vara Federal da Seção Judiciária do Distrito Federal como competente para análise de eventuais medidas de urgência.

Os casos foram decididos a partir de voto-vista do Ministro Teori Albino Zavascki, que decidiu pelo não acolhimento dos incidentes, sob argumento de que "não foi demonstrada, nem sequer alegada, a existência de manifestação de juízes disputando a competência ou afirmando a incompetência em relação às demandas elencadas na petição" e que "a simples possibilidade de sentenças divergentes sobre a mesma questão jurídica não configura, por si só, conflito de competência"189.

Verifica-se da leitura do voto, que Zavascki não apenas entendeu que a coexistência de demandas coletivas não cria potencialmente o risco de decisões conflitantes, como que as demandas individuais não podem ser obstadas em função da existência das coletivas. Segundo o ministro, os direitos individuais não se enquadrariam como direitos transindividuais, sendo que podem ser tutelados tanto por ação coletiva, quanto por ação individual, cabendo ao autor da demanda individual optar por aderir (ou não) à demanda coletiva.

Com isto, o ministro conclui que "(a) a ação individual pode ter curso independente da ação coletiva; (b) a ação individual só se suspende por iniciativa do seu autor; e (c) não

\footnotetext{
${ }^{189}$ CC 47.731:

PROCESSO CIVIL. CONFLITO DE COMPETÊNCIA. DEMANDAS COLETIVAS E INDIVIDUAIS PROMOVIDAS CONTRA A ANATEL E EMPRESAS CONCESSIONÁRIAS DE SERVIÇO DE TELEFONIA. CONTROVÉRSIA A RESPEITO DA LEGITIMIDADE DA COBRANÇA DE TARIFA DE ASSINATURA BÁSICA NOS SERVIÇOS DE TELEFONIA FIXA. CONFLITO NÃO CONHECIDO.

CC 48.177:

PROCESSO CIVIL. CONFLITO DE COMPETÊNCIA. DEMANDAS COLETIVAS E INDIVIDUAIS PROMOVIDAS CONTRA A ANATEL E EMPRESAS CONCESSIONÁRIAS DE SERVIÇO DE TELEFONIA. CONTROVÉRSIA A RESPEITO DA LEGITIMIDADE DA COBRANÇA DE TARIFA DE ASSINATURA BÁSICA NOS SERVIÇOS DE TELEFONIA FIXA.
} 
havendo pedido de suspensão, a ação individual não sofre efeito algum do resultado da ação coletiva, ainda que julgada procedente."

Referido entendimento foi rebatido por Kazuo Watanabe ${ }^{190}$, que emitiu parecer atestando que o caso envolveria interesses pseudoindividuais, razão pela qual as demandas individuais sequer seriam admitidas na hipóteses e, caso o fossem, deveriam ser decididas em conjunto, para evitar-se decisões conflitantes. Veja-se trecho do mencionado parecer sobre o tema:

Qualquer modificação na cesta tarifária, com a exclusão da tarifa de assinatura, como é previsto nas ações coletivas e nas demandas pseudoindividuais acima mencionadas, afetará profundamente o equilíbrio econômico-financeiro do contrato de concessão, que é um dos direitos básicos da concessionária, e sem esse equilíbrio estará irremediavelmente comprometido o cumprimento das várias obrigações e metas estabelecidas no contrato de concessão.

\section{(...)}

As ações individuais, caso fossem admissíveis, e não o são, devem ser decididas de modo global, atingindo todos os usuários, em razão da natureza incindível da relação jurídica substancial. Todas elas, na verdade, buscam a tutela de posições individuais que "se inserem homogeneamente na situação global" (na expressão de Barbosa Moreira, v. citação supra $^{191}$ ), de modo que a decisão deve ser do mesmo teor para todos que se encontrem na mesma situação jurídicosubstancial, o que significa que uma só demanda seria suficiente para a proteção da totalidade de usuários. Essas ações individuais são similares às ações individuais movidas por um ou alguns acionistas para a anulação de deliberação assemblear ou à ação individual movida por uma vítima contra a poluição ambiental praticada por uma indústria.

\footnotetext{
${ }^{190}$ WATANABE, Kazuo. Relação entre demanda coletiva e demandas individuais. In GRINOVER, Ada Pellegrini; MENDES, Aluísio Gonçalves de Castro e WATANABE, Kazuo (coord.). Direito Processual Coletivo e o Anteprojeto de Código Brasileiro de Processos coletivos. São Paulo: Ed. RT, 2007, p. 160 ${ }^{191}$ A citação a José Carlos Barbosa Moreira refere-se à obra Litisconsórcio unitário. Rio de Janeiro: Forense, 1972. p. $83-84$
} 
O entendimento de Kazuo Watanabe é criticado, no entanto, na medida em que violaria a inafastabilidade da jurisdição.

Por outro lado, o entendimento emanado parece ser uma evolução processual, vez que até mesmo inspirou a proposição ora trazida no projeto de Código de Processo (incidente de coletivização). Havendo diversos interesses, em que se verifica uma questão de direito comum aos indivíduos, deve-se buscar uma solução isonômica, evitando-se o proferimento de decisões conflitantes e, por conseguinte, a insegurança jurídica.

Tal entendimento auxilia e corrobora uma definição qualitativa dos legitimados, para que estes atuem efetivamente em juízo, tutelando os interesses envolvidos em demanda única, evitando que haja diversas ações individuais.

\subsection{Expurgos Inflacionários das Cadernetas de Poupança}

Contrariamente ao entendimento emanado por Teori Albino Zavascki, referido supra, houve recente manifestação da Segunda Seção, através de voto do Ministro Sidnei Beneti, no julgamento do REsp 1.110.549/RS.

Referida decisão é uma evolução no sistema e reforça a adequada representatividade por parte dos legitimados em ações coletivas, que irão defender em demanda única todos os interesses envolvidos, evitando diversas demandas individuais, com decisões conflitantes.

Trata-se de julgamento de recurso repetitivo relativo à suspensão de ação individual, em virtude de ação coletiva, sem qualquer requerimento da parte, em demanda que discute os expurgos inflacionários ocorridos em virtude de Planos Econômicos.

No julgamento do caso, o i. Ministro reconheceu que não haveria violação ao disposto nos arts. 81 e $104^{192}$ do CDC, vez que a suspensão do processo individual, em 192 Art. 104. As ações coletivas, previstas nos incisos I e II e do parágrafo único do art. 81, não induzem
litispendência para as ações individuais, mas os efeitos da coisa julgada erga omnes ou ultra partes a que
aludem os incisos II e III do artigo anterior não beneficiarão os autores das ações individuais, se não for 
vista da existência de ação coletiva se daria "em atenção ao interesse público de preservação da efetividade da Justiça”. O entendimento asseverado se dá sob fundamento de que o sistema da Lei dos Processos Repetitivos não seria suficiente para obstar o ilegítimo (e desnecessário) trâmite das ações individuais por todas as instâncias ${ }^{193}$.

O i. ministro assevera, ainda que

No ato de suspensão não se devem levar em conta peculiaridades da contrariedade (p. ex., alegações diversas, como as de ilegitimidade de parte, de prescrição, de irretroatividade de lei, de nomeação de gestor, de julgamento por Câmaras Especiais e outras que porventura surjam, ressalvada, naturalmente, a extinção devido à proclamação absolutamente evidente e sólida de pressupostos processuais ou condições da ação), pois, dada a multiplicidade de questões que podem ser enxertadas pelas partes, na sustentação de suas pretensões, o não sobrestamento devido a acidentalidades de cada processo individual levaria à ineficácia do sistema.

As questões incidentais deveriam, por isso, serem apreciadas no futuro, após o julgamento de mérito da lide coletiva.

A questão cerne da discussão em tela refere-se ao conflito entre o princípio da inafastabilidade da jurisdição e a celeridade e economia processuais, bem como a isonomia e segurança jurídica. No caso, a mitigação ocorrida à inafastabilidade da jurisdição não apenas impede o proferimento de decisão final em demanda individual, que eventualmente poderia conflitar com demanda coletiva, como impede o próprio prosseguimento da lide.

requerida sua suspensão no prazo de trinta dias, a contar da ciência nos autos do ajuizamento da ação coletiva.

193 RECURSO REPETITIVO. PROCESSUAL CIVIL. RECURSO ESPECIAL. AÇÃO COLETIVA. MACRO-LIDE. CORREÇÃO DE SALDOS DE CADERNETAS DE POUPANÇA. SUSTAÇÃO DE ANDAMENTO DE AÇÕ̃ES INDIVIDUAIS. POSSIBILIDADE. 1.- Ajuizada ação coletiva atinente a macro-lide geradora de processos multitudinários, suspendem-se as ações individuais, no

aguardo do julgamento da ação coletiva. 2.- Entendimento que não nega vigência aos aos arts. 51 , IV e $\S 1^{\circ}$, 103 e 104 do Código de Defesa do Consumidor; 122 e 166 do Código Civil; e $2^{\circ}$ e $6^{\circ}$ do Código de Processo Civil, com os quais se harmoniza, atualizando-lhes a interpretação extraída da potencialidade desses dispositivos legais ante a diretriz legal resultante do disposto no art. 543-C do Código de Processo Civil, com a redação dada pela Lei dos Recursos Repetitivos (Lei n. 11.672, de 8.5.2008). 3.- Recurso Especial improvido. 
Apesar de tal mitigação, parece razoável que haja uma decisão uníssona para os casos que envolvem a mesma questão de direito. Isto porque, muitas vezes, os autores das demandas ficam a mercê do entendimento individual dos magistrados, em verdadeira loteria de decisões. O proferimento de decisão em uma demanda coletiva, bem instruída, e bem representada, traz benefício ao indivíduo. E, mais, deixa de sobrecarregar o judiciário com dezenas de decisões e recursos protelatórios, sobre questões que podem ser decididas de maneira uniforme.

A decisão proferida vai ao encontro da atual tendência processual pátria, reconhecida, inclusive, pelo Projeto de Código de Processo, em seu incidente de resolução de demandas repetidas.

\section{Considerações Conclusivas}

A legitimidade na ação coletiva e principalmente no mandado de segurança coletivo ainda é bastante discutida, tendo ocorrido relevantes avanços normativos e interpretativos (pela doutrina e jurisprudência), com objetivo de ampliar a proteção dos direitos difusos, coletivos e individuais homogêneos.

Surgiram novos instrumentos e procedimentos que têm por base, principalmente, a ideia da representação adequada e pertinência temática, que se desenvolvem com grande força no país atualmente, para fins de determinação dos legitimados para a tutela de direitos coletivos lato sensu, especialmente no que se refere ao mandamus coletivo.

A amplitude da tutela coletiva por meio do writ coletivo foi ampliada, reconhecendo-se, inclusive, sua efetividade para proteção de direitos difusos.

Apesar da legitimação ope legis que vige no país, a tendência é que o rol dos legitimados seja ampliado, entendendo-se como exemplificativas as disposições contidas no art. 5”, LXX, "a” e "b”, da CF e art. 21, caput, da Lei 12.016/2009. 
Plenamente razoável, hoje, a legitimação do Ministério Público e da Defensoria Pública para impetração de mandado de segurança coletivo, adotando-se uma interpretação sistêmica dos instrumentos protetivos dos direitos coletivos. 


\section{BIBLIOGRAFIA}

ALMEIDA, Gregório Assagra. Direito processual coletivo brasileiro: um novo ramo do direito processual. São Paulo: Saraiva, 2003, p. 515-516.

AMARAL, Paulo Osternack; e SILVA, Ricardo Alexandre. Mandado de Segurança Coletivo. Revista Dialética de Direito Processual no 105, dez-2011, pp. 88-103.

ARAÚJO, Rodrigo Souza Mendes de. A representação adequada nas ações coletivas. Dissertação de mestrado em Direito, São Paulo, PUC, 2007.

ARRUDA ALVIM, Eduardo. Mandado de segurança no direito tributário. São Paulo: Ed. RT, 1998, pp. 57-58.

. Aspectos do Mandado de Segurança Coletivo à luz da Lei 12.016/2009, v. 105, n. 406, Rio de Janeiro: Forense, 2009, pp. 139-170.

ARRUdA AlVIM, José Manoel de. Código de Processo Civil Comentado. São Paulo: Editora Revista dos Tribunais, vol. 1.

Substituição Processual, Prova escrita em concurso de livre-docência. Doutrinas Essenciais de Processo Civil, v. 3, São Paulo: Revista dos Tribunais, 2011, p. 435.

ARRUDA ALVIM NETTO, José Manoel de. Ação Civil Pública e Eficácia Da Sentença, v. 1, São Paulo, Ed. RT, 2011, p. 61 e ss.

ARRUDA ALVIM WAMBIER, Teresa. Apontamentos sobre as ações coletivas. Revista de Processo. v. 75. São Paulo: Ed. RT, jul.-set. 1994, p. 273-283.

AURELLI, Arlete Inês. Legitimidade como condição para o exercício da ação de mandado de segurança, conforme a Lei n. 12.016/2009, in Panorama Atual das tutelas individual e coletiva, São Paulo: Saraiva, 2011, pp. 123-130.

BARBI, Celso Agricola. Do mandado de segurança. 6 $^{\mathrm{a}}$ ed. Rio de Janeiro: Forense, p. 283. . Mandado de Segurança na Constituição de 1988. v. 16. Porto Alegre: Ajuris, 1989, p. 48-51. 
Mandado de segurança na Constituição de 1988. São Paulo:

Saraiva, 1990, p. 73

BARBOSA MOREIRA, José Carlos. Ações coletivas na Constituição Federal de 1988. Revista de Processo. v. 61. São Paulo: Ed. RT, jan.-mar. 1992, pp. 82-84 e 189-190.

José Carlos. Sobre pressupostos processuais. Temas de direito processual. São Paulo: Saraiva, 1989.

BARROSO, Luís Roberto. A proteção coletiva dos direitos no Brasil e alguns aspectos da class action norte-americana. Revista de Processo. v. 130. São Paulo: Ed. RT, dez. 2005. p. 131-153.

. Interpretação e aplicação da constituição: fundamentos de uma dogmática constitucional transformadora. 6a ed., São Paulo: Saraiva, 2004, p. 196.

BENJAMIN, Antonio Herman V., Legitimidade Ativa e Objeto Material no Mandado de Segurança Coletivo, Revista dos Tribunais, v. 895, São Paulo: Ed. RT., 2010, p. 9 e ss.

BEZERRA, Adão Bonfim. Da proteção judicial dos interesses individuais. In: CURY, Munir; AMARAL E SILVA, Antônio Fernando do; GARCIA MENDES, Emílio (coords.). Estatuto da Criança e do Adolescente comentado: comentários jurídicos e sociais. São Paulo: Malheiros, 2000.

BONAVIDES, Paulo. Ciência Política, Rio de Janeiro: FGV, 1967, p. 283.

BOTELHO DE MESQUITA, José Ignacio. O Mandado de Segurança - Contribuição para o seu estudo. Revista dos Tribunais, v. 825, São Paulo: RT, 2004, pp. 76 e ss.

BUENO, Cassio Scarpinella. Mandado de segurança. São Paulo: Saraiva, 2002. pp. 28-29. A nova lei do Mandado de Segurança, São Paulo: Saraiva, 2009. pp. 28-29; 126-127.

As class actions norte-americanas $e$ as ações coletivas brasileiras: pontos para uma reflexão conjunta. Revista de processo, ano $21, \mathrm{n}$. 82, abr-jun 1996, pp. 102 e ss. 
A Legitimidade Ativa no Mandado de Segurança Coletivo: art.

5. ${ }^{o}$, LXX, da CF/1988, Doutrinas Essenciais de Processo Civil, v. 9, São Paulo: Ed. RT, 2011, p. 345.

BULOS, Uadi Lamêgo. Mandado de segurança coletivo: em defesa dos partidos políticos, associações, sindicatos, entidades de classe: Doutrina, jurisprudência e legislação. São Paulo: Ed. RT, 1996. p. 64.

BUZAID, Alfredo. Do agravo de petição no sistema do Código de Processo Civil. $2^{\mathrm{a}}$ ed. São Paulo: Saraiva, 1956. p. 115-121.

Do Despacho Saneador. Estudos de Direito, v. 1, São Paulo:

Saraiva, 1972, p. 41- 42.

CABRAL, Antonio do Passo. Despolarização do processo e "zonas de interesse": sobre a migração entre os polos da demandas, in O Novo Processo Civil Brasileiro - Direito em Expectativa, Rio de Janeiro: Ed. Forense, 2011. pp. 162-170.

CALMON DE PASSOS, José Joaquim. Em torno das condições da ação: a possibilidade jurídica do pedido. Revista de Direito Processual Civil, vol. 4, Rio de Janeiro: Saraiva, 1964. pp. 61-63.

Mandado de Segurança Coletivo, Mandado de Injunção e Habeas Data - Constituição e Processo, Rio de Janeiro: Forense, 1989, pp. 12-35.

CÂMARA, Alexandre Freitas. Legitimidade da Defensoria Pública para ajuizar ação civil pública: um possível primeiro pequeno passo em direção a uma grande reforma. Revista Autônoma de Processo. n. 3. Curitiba: Juruá, 2007. p. 13-19.

Será o Fim da "Condição da Ação"? Uma Resposta a Fredie

Didier Jr.. Revista de Processo, v. 197, São Paulo: Ed. RT, 2011. pp. 263 e ss.

CAMBI, Eduardo. Legitimidade do Ministério Público para Impetrar Mandado de Segurança Coletivo, Revista de Processo, v. 203, São Paulo: Ed. RT, 2012, p. 121 e ss.

CAMPOS, Ricardo Ribeiro. Legitimidade do Ministério Público para defesa de interesses individuais homogêneos: sua compreensão a partir da teoria dos poderes implícitos e da 
interpretação sistemática da Constituição. Revista de Direito Constitucional e Internacional. vol. 50. São Paulo: Ed. RT, jan.-mar. 2005. p. 187-199.

CANOtilho, J.J. Gomes. Direito Constitucional e Teoria da Constituição, $5^{\mathrm{a}}$ ed., Coimbra: Almedina, 2002, p. 378/388.

CARNEIRO, Athos Gusmão. Anotações sobre o mandado de segurança coletivo. Ajuris 54/55. Porto Alegre: Ajuris, mar. 1992.

- Anotações sobre o Mandado de Segurança Coletivo, nos termos da Lei 12.016/2009, Doutrinas Essenciais de Processo Civil, v. 9, São Paulo: Ed. RT, 2011, p. 769.

CARVAlHO, Ivan Lira de. O Mandado de Segurança Coletivo e os Partidos Políticos, Revista de Processo, vol. 72, São Paulo: RT, 1993, p. 75 e ss.

CERQUEIRA, Luís Otávio Sequeira de. Mandado de Segurança segundo a Lei n. 12.016, de 07 de agosto de 2009, de Humberto Theodoro Jr., Revista de Processo, v. 182, São Paulo: Ed. RT, 2010, p. 423.

CINTRA, Antonio Carlos de Araújo; Dinamarco, Cândido Rangel; Grinover, Ada Pellegrini. Teoria Geral do Processo. São Paulo: Editora Malheiros; 2007, p. 266-269.

CHIOVENDA, Giuseppe. Principii di direito processuale civile, $3^{\mathrm{a}}$ ed., Roma, 1923, p. 597.

COSTA, Susana Henriques da. O Controle Judicial da representatividade adequada: uma análise dos sistemas norte-americano e brasileiro, in SALLES, Carlos Alberto de (coord.). As grandes transformações do processo civil brasileiro: homenagem ao Professor Kazuo Watanabe. São Paulo: Quartier Latin, 2009. p. 959.

CRETELlA JR., José. Do mandado de Segurança Coletivo. Rio de Janeiro: Forense, 1999. pp. 18-25; 59-66; 70-79.

CRUZ E TUCCI, José Rogério. Class action e mandado de segurança coletivo. São Paulo: Saraiva, 1990. n. 2.2 e 2.6.

CUNHA, Leonardo Carneiro da. Será o fim da categoria condições da ação? Uma 
intromissão no debate travado entre Fredie Didier Jr. e Alexandre Freitas Câmara. Revista de Processo, v. 198, São Paulo: Ed. RT, 2011, pp. 235 e ss.

DIDIER JR., Fredie. Assistência, recurso de terceiro e denunciação da lide em causas coletivas. In: Aspectos polêmicos e atuais sobre os terceiros no processo civil (e assuntos afins); ARRUDA ALVIM WAMBIER, Teresa (orgs.).. São Paulo: Ed. RT, 2004.

Será o fim da categoria "condição da ação"? Um elogio ao projeto do novo Código de Processo Civil, Doutrinas Essenciais de Processo Civil. vol. 2. São Paulo: Ed. RT, out 2011, pp. 323 e ss.

Possibilidade jurídica do pedido: um novo enfoque do problema - Pela proscrição. Revista de Direito Processual Civil, vol. 13. n. 13, Curitiba: Gênesis, 1999, pp. 449-463.

O Controle Jurisdicional da Legitimação Coletiva e as Ações Coletivas Passivas (o artigo 82 do CDC). Revista Magister de Direito Civil e Processual $n^{\circ}$ 6, mai-jun 2005, pp. 70-79.

; ZANETI JR., Hermes. Curso de Direito Processual Civil: Processo Coletivo. Salvador: JusPodivm, 2007.

DINAMARCO, Cândido Rangel. Instituições de Direito Processual Civil. São Paulo: Malheiros, 2001. vol. 3, p. 128.

Instituições de Direito Processual Civil. São Paulo: Malheiros, 2001. vol. 2, pp. 616-618.

Instituições de Direito Processual Civil, II, $2^{\mathrm{a}}$ ed. São Paulo: Malheiros, 2002, p. 306. . Execução Civil. São Paulo: Ed. RT, 1973, p. 140-150.

FAGUNDES, Miguel Seabra. O Controle dos atos administrativos do Poder Judiciário, $5^{\mathrm{a}}$ ed., Rio de Janeiro: Forense, 1979, p. 259.

FARIA, Luiz Alberto Gurgel. Mandado de Segurança Coletivo - Legitimação e Interesse. Revista dos Tribunais, v. 687, São Paulo: Ed. RT, 1993, pp. 34-39. 
FERRARESI, Eurico. A pessoa física legitimada ativa à ação coletiva. In: Grinover, Ada Pellegrini; Watanabe, Kazuo et al (coords.). Direito processual coletivo e o Anteprojeto de Código Brasileiro de Processos Coletivos. São Paulo: Ed. RT, 2007.

FERRAZ, Antônio Augusto Mello de Camargo; MILARÉ, Édis; NERY JR., Nelson. A ação civil pública e a tutela jurisdicional dos interesses difusos. São Paulo: Saraiva, 1984.

FIGUEIREDO, Lucia Valle. Mandado de segurança coletivo. Revista de Direito Público 3/1993. São Paulo: Malheiros, 1993. pp. 145-160.

FISS, Owen. Um novo Processo Civil: estudos norte-americanos sobre jurisdição, constituição e sociedade. São Paulo: Ed. RT, 2004. pp. 51-52

FORNACIARI, Flávia Hellmeister Clito. Representatividade adequada nos processos coletivos. Tese de Doutorado, São Paulo, Faculdade de Direito da USP, 2010.

FRANCO NETO, Ary Azevedo. Mandado de Segurança Coletivo - Legitimação das Entidades Associativas para a Defesa de Interesses Coletivos, Revista dos Tribunais, v. 677, São Paulo: Ed. RT, 1992, p. 7.

GAllotTI, Carolina. Pertinência Temática nas Ações Coletivas, Revista de Processo, v. 142, São Paulo: Ed. RT, 2006, p. 168.

GARCIA, Pedro Carlos Sampaio. O sindicato e o processo: a coletivização do processo do trabalho. São Paulo: Saraiva, 2002, p. 150.

GIDI, Antonio. A representação adequada nas ações coletivas brasileiras: uma proposta. Revista de Processo. vol. 108. São Paulo: Ed. RT, out.-dez. 2002. pp. 63 e ss.

Assistência em ações coletivas. Revista de Processo. vol. 88. São Paulo: Ed. RT, out.1997, p. 269.

Coisa julgada e litispendência em ações coletivas. São Paulo: Saraiva, 1995, pp. 41 e 43.

Código de Processo Civil Coletivo. Um modelo para países de direito escrito. Revista de Processo. v. 111. São Paulo: Ed. RT, 2003, p.192 e ss. 
Legitimidade para Agir em Ações Coletivas, Revista de Direito do Consumidor, v. 9, São Paulo: Ed. RT, 2011, p. 285 e ss.

Rumo a um Código de Processo Civil Coletivo - A codificação das ações coletivas no Brasil. Rio de Janeiro: Forense, 2008.

Class Action como instrumento de tutela coletiva dos direitos. As ações coletivas em uma perspectiva comparada. São Paulo: Ed. RT, 2007, pp. 72 e ss.

GOMES, Orlando. Curso de Direito do Trabalho, v. 2, p. 723.

GOMES JR., Luiz Manoel. Curso de direito processual civil coletivo. Rio de Janeiro: Forense, 2005, p. 85.

Mandado de Segurança Coletivo - Legitimidade e Objeto Análise dos seus Principais Aspectos - Lei 12.016/2009. Revista dos Tribunais, v. 898, São Paulo: Ed. RT, 2010, p. 79 e ss.

e FAVRETO, Rogério. Mandado de segurança coletivo Legitimidade e objeto - Análise dos seus principais aspectos - Lei 12.016/2009, v. 898, São Paulo: Ed. RT, 2010. p. 103.

GONÇALVES NETO, Francisco Neto. Mandado de Segurança Coletivo e o Sindicato, LTr $n^{\circ} 53$, out 89.

GRINOVER, Ada Pellegrini. A ação civil pública e a defesa de interesses individuais homogêneos. Revista de Direito do Consumidor. vol. 5. São Paulo: Ed. RT, jan.-mar. 1993. p. 206.

As condições da ação penal. Revista Brasileira de Ciências Criminais, v. 69, 2007, pp. 179-199.

Ação civil pública e ação popular: aproximações e diferenças. In: SALLES, Carlos Alberto de (org.). Processo civil e interesse público: o processo como instrumento de defesa social. São Paulo: Ed. RT, 2003.

Legitimidade da Defensoria Pública para Ação Civil Pública,

Revista de Processo, vol. 165, Nov / 2008. p. 299. 
Mandado de Segurança Coletivo: legitimação, objeto e coisa julgada, Revista de Processo, nº 58, São Paulo: Ed. RT, 1990, pp. 77-79; 101.

. Mandado de segurança coletivo: legitimação, objeto e coisa julgada. São Paulo: Saraiva, 1991. p. 287.

. Novas tendências em matéria de ações coletivas nos países de Civil Law, Doutrinas Essenciais de Processo Civil, v. 9, São Paulo: Ed. RT, 2011, p. 1101 e ss.

. Os Processos Coletivos nos Países de Civil Law e Common Law: uma análise de direito comparado. São Paulo: Ed. RT, 2008, pp. 229 e ss.

LEAL, Márcio Mafra. Ações Coletivas: História, Teoria e Prática. Sérgio Antonio Fabris Editor, Porto Alegre, 1998, pp. 21-23.

LEONEL, Ricardo de Barros. Manual do processo coletivo. São Paulo: Ed. RT, 2002. pp. 159-167.

. Anteprojeto de Código Brasileiro de Processos Coletivos: a Ação Popular, a Ação de Improbidade, o Mandado de Segurança Coletivo e o Mandado de Injunção, Revista Magister de Direito Civil e Processual nº 6, mai-jun 2005, pp. 81-95.

LENZA, Pedro. Teoria Geral da Ação Civil Pública. São Paulo: Ed. RT, 2003, p. 179-180. . Manual do processo coletivo. 2. ed. São Paulo: Ed. RT, 2011.

LEYSER, Maria de Fátima V. Ramalho, Mandado de Segurança Coletivo, Revista de Processo, v. 86, São Paulo: Ed. RT, 1997, p. 362.

LIEBMAN, Enrico Tullio. Manuale di diritto processuale civile. 3. ed. Milão: Giuffrè, 1973. n. 73, vol. I, p. 117.

Manual de Direito Processual Civil. vol. I, Rio de Janeiro: Forense, 1984. P. 150-155. 
LIMA, Sebastião de Oliveira. Mandado de Segurança Coletivo e Seus Principais Problemas. Revista Trimestral de Direito Público, no 3, São Paulo: Malheiros, 1993, p. 135-159.

MANCUSO, Rodolfo de Camargo. Ação civil pública. 9. ed. São Paulo: Ed. RT, 2004. . Ação civil pública- em defesa do meio ambiente, do patrimônio cultural e dos consumidores. $9^{\mathrm{a}}$ ed. São Paulo: Revista dos Tribunais, 2004, pp. 59-70; 197.

A Resolução dos Conflitos e a Função Judicial no Contemporâneo Estado de Direito, $1^{\text {a }}$ Ed., São Paulo: Ed. RT, 2009. p. 107-108. . Interesses Difusos: Conceito e legitimação para agir. São Paulo: Ed. RT, 1988. p. 105. Interesses Difusos: Conceito e legitimação para agir. $5^{\mathrm{a}}$ ed., São Paulo: Revista dos Tribunais, 2001. p. 192. Interesses Difusos: Conceito e legitimação para agir. 6. ed. São Paulo: Ed. RT, 2004. - Interesses Difusos e Coletivos, Revista de Direito do Consumidor, vol. 22, Abr / 1997. pp. 36 e ss. . Ação Popular, $2^{\mathrm{a}}$ ed., São Paulo: Ed. Revista dos Tribunais, 1996. p. 117-118. . Ação popular - proteção ao erário, do patrimônio público, da moralidade administrativa e do meio ambiente. $5^{\text {a }}$ ed., v. 1, São Paulo: Revista dos Tribunais, 2003, pp. 136 e ss.

- Uma análise crítica comparativa entre os objetos e legitimações ativas nas ações vocacionadas à tutela dos interesses metaindividuais: mandado de segurança coletivo, ação civil pública, ações do código de defesa do consumidor e ação popular, Justitia, v. 160. São Paulo: Órgão Oficial do Ministério Público do Estado de São Paulo, 1992, p. 193-194. 
. Manual do consumidor em juízo. 2 ed. São Paulo: Saraiva,

1998 , pp. 8 e ss.

Interesses Difusos: Conceito e legitimação para agir. 8. ed. São

Paulo: Ed. RT, 2013, p. 207 a 229.

MAIA, Diogo Campo Medina. Ação coletiva passiva. Rio de Janeiro: Lumen Juris, 2009.

MARINONI, Luiz Guilherme. Manual do processo de conhecimento. 4. ed. São Paulo: Ed. RT, 2005. p. 711.

MARQUES, José Frederico. Instituições de Direito Processual Civil. $4^{\mathrm{a}}$ ed.. v. 2, Rio de Janeiro: 1971, pp. 24-26.

. Manual de Direito Processual, v. 1, 7. a ed., São Paulo: Ed.

Saraiva, 1980, p. 178.

MAZZILLI, Hugo Nigro. A Defesa dos Interesses Difusos em Juízo. $23^{\text {a }}$ ed. São Paulo: Saraiva, 2010.

A Defesa dos Interesses Difusos em Juízo: Meio ambiente, consumidor e patrimônio cultural, patrimônio público e outros interesses. $24^{\mathrm{a}}$ ed. São Paulo: Saraiva, 2011. p. 40-55.

MEIRELLES, Hely Lopes. Mandado de Segurança, ação popular e ação civil pública, $11^{\mathrm{a}}$ ed., São Paulo: Ed. RT, 1987, pp. 4-5; 33-34.

MIRRA, Álvaro Luiz Valery, Associações civis e a defesa dos interesses difusos em juízo: do direito vigente ao direito projetado, in GRINOVER, Ada Pellegrini e outros (coord.). Direito Processual Coletivo e anteprojeto de Código Brasileiro de Processos Coletivos. São Paulo: Ed. RT, 2007, p. 114-135.

MOEMEZZO, Marta Casadei. Mandado de Segurança Coletivo: aspectos polêmicos. São Paulo: LTr, 2000, pp. 21-73.

MORAIS, Dalton Santos. A Legitimidade Passiva e a Defesa do Poder Público na Nova Lei do Mandado de Segurança - Lei 12.016/2009, Revista de Processo, v. 184. São Paulo: Ed. RT, 2010, p. 195 e ss. 
MOREIRA, José Carlos Barbosa. Litisconsórcio unitário. Rio de Janeiro: Forense, 1972. p. $83-84$

NEGRÃO, Ricardo. Ações coletivas: enfoque sobre a legitimidade ativa. São Paulo: Leud, 2004.

NERY JR., Nelson. Ação civil pública no processo do trabalho. In: MILARÉ, Édis (coord.). Ação civil pública: Lei 7.347/1985 - 15 anos, São Paulo: Ed. RT, 2001, p. 573574.

Condições da Ação. Doutrinas Essenciais de Processo Civil, vol.

2. São Paulo: Ed. RT, out 2011.p. 179.

. Código de processo civil comentado. 5. ed. São Paulo: Ed. RT, 2001, p. 1866.

. e ANDRADE NERY, Rosa Maria. Código de Processo Civil comentado e legislação processual civil extravagante em vigor. $3^{\mathrm{a}}$ ed.., São Paulo: Ed. RT, 1997, p. 1395.

Mandado de segurança coletivo. Revista de Processo, $n^{\circ}$ 57, São

Paulo: RT, p. 156.

NOBRE JR., Edilson Pereira. Mandado de Segurança Coletivo e sua impetração por partido político, v. 847, São Paulo: Ed. RT, maio/2006, pp. 40-64.

OLIVEIRA, Eduardo Ribeiro de. Condição da Ação: a possibilidade jurídica do pedido. Doutrinas Essenciais de Processo Civil, v. 2, São Paulo: Ed. RT, 2011, p. 135.

OLIVEIRA, Francisco Antonio. Mandado de Segurança e Controle Jurisdicional. $2^{\mathrm{a}}$ ed. São Paulo: Ed. RT, 1996, pp. 23-26.

OLIVEIRA, Lourival Gonçalves de, Interesse Processual e Mandado de Segurança Coletivo, Revista de Processo, v. 56, São Paulo: Ed. TR, 1989, p. 75 e ss.

PACHECO, José da Silva. As Ações Constitucionais Típicas na Constituição de 1988, in Seleções Jurídicas - ADV/COAD, Rio de Janeiro, 1989, p. 9. 
Mandado de Segurança e outras ações típicas. $5^{\mathrm{a}}$ ed., São Paulo:

Ed. RT, 2008, pp. 93-122.

PONTES DE MIRANDA. Comentários ao Código de Processo Civil, v. 4, $2^{\mathrm{a}}$ ed., Rio de Janeiro: Forense, 1959, p. 431.

RÉ, Aluísio Iunes Monti Ruggeri. A Defensoria Pública como instrumento de acesso à justiça coletiva: legitimidade ativa e pertinência temática. Revista de Processo. vol. 167. São Paulo: Ed. RT, jan. 2009. p. 231-249.

REGO, Hermenegildo de Souza. Interesses difusos e conceitos tradicionais da legitimação “ad causam”, interesse de agir, representação, substituição processual e limites subjetivos e objetivos da coisa julgada (reformulação desses institutos processuais), Revista de Processo, v. 43, São Paulo: Ed. RT, p. 260 e ss.

RIBEIRO, Fávila. Direito Eleitoral, Rio de Janeiro: Forense, 1976, p. 203.

RIBEIRO, Rodrigo Pereira Martins. O Ministério Público na jurisdição coletiva: a tutela do direito individual homogêneo. In: PINHO, Humberto Dalla Bernardina de (org.). Temas contemporâneos de direito processual. Rio de Janeiro: Lumen Juris, 2004.

ROQUE, Andre Vasconcelos. Aspectos Polêmicos do Mandado de Segurança Coletivo: Evolução ou Retrocesso?, Revista de Processo, v. 203, São Paulo: Ed. RT, 2012, p. 39 e ss.

SANTOS, Moacyr Amaral. Primeiras Linhas de Direito Processual Civil. 29a ed, vol. I, São Paulo: Saraiva, 2012, pp. 195 e ss.

. Primeiras linhas de direito processual civil - v. 1. 21. ed. São Paulo: Saraiva, 1999, pp. 170 e ss.

Natureza Jurídica do Mandado de Segurança. Revista de Direito Privado, $\mathrm{n}^{\mathrm{o}} 17$, pp. 16 e ss.

SANTOS, Ernane Fidelis. Mandados de segurança e de injunção, São Paulo: Saraiva, 1990, p. 132.

SHIMURA, Sérgio Seiji. O papel da associação na ação civil pública. In: MAZZEI, Rodrigo; NOLASCO, Rita Dias (orgs.). Processo civil coletivo. São Paulo: Quartier Latin, 
2005.

SILVA, José Afonso da Silva. Curso de Direito Constitucional Positivo, 8. a ed., São Paulo, 1992, p. 411.

SILVA, Marta Maria Gomes e, LEHFELD Lucas de Souza. A legitimação ativa no mandado de segurança coletivo e a Lei 12.016/2009, Revista de Direito Constitucional e Internacional, vol. 70, São Paulo: Ed. RT, 2010, p. 143 e ss.

SILVA, Marta Maria Gomes. Considerações sobre a legitimação ativa no mandado de segurança coletivo, Revista de Processo, v. 171, São Paulo: Ed. RT, 2009, p. 343 e ss.

SILVA, Ovídio Araújo Baptista da. Teoria Geral do Processo Civil, 6 ${ }^{\mathrm{a}}$ ed., São Paulo: Revista dos Tribunais, 2011, p. 89.

SILVA, Ricardo Alexandre da. Legitimidade Extraordinária (Substituição Processual) no Mandado de Segurança: Interpretação do art. $3^{\circ}$ da lei 12.016/2009, Revista de Processo, v. 178, São Paulo: Ed. RT, 2009, p. 180 e ss.

SILVA, Sandra Lengruber da. Elementos das ações coletivas. São Paulo: Método, 2004.

SILVA JR., Walter Nunes, Condições da Ação e Pressupostos Processuais, Revista de Processo, v. 64, São Paulo: Ed. RT, 1991, p. 70.

SOUZA, Luiz Antonio de. A tutela jurisdicional coletiva e sua efetividade. In: MILARÉ, Édis (coord.). A ação civil pública após 25 anos. São Paulo: Ed. RT, 2010.

SUNDFELD, Carlos Ari. Mandado de segurança coletivo na Constituição de 1988, Revista de Direito Público, nº 89, São Paulo: RT, p. 41.

SZAMIAWSKI, Elimar. O Sindicato e suas relações com a justiça do trabalho, São Paulo: Ed. RT, 1986, p. 46 e ss.

TEIXEIRA, Sálvio de Figueiredo. Mandado de Segurança - Apontamentos, Revista dos Tribunais, v. 624, 1987, p. 11 e ss.

TESHEINER, José Maria Rosa. Partes e legitimidade nas ações coletivas. Revista de Processo, vol. 180, São Paulo: Ed. RT, fev. 2010, pp. 9-16. 
. Mandado de Segurança Coletivo, Revista de Processo, v. 182, São Paulo: Ed. RT, 2010, p. 9 e ss.

THEODORO JR., Humberto. O mandado de segurança segundo a Lei n. 12.016, de 7 de agosto de 2009, Rio de Janeiro: Forense, 2009.

. Curso de Direito Processual Civil, v. I, 20ª ed., Rio de

Janeiro: Forense, p. 52.

TUCCI, Rogério Lauria. Aspectos Modernos do Conceito de Ação. Doutrinas Essenciais de Processo Civil, v. 2, São Paulo: Ed. RT, 2011, p. 59.

V. PASCHOAL, Maximiliam Fierro. A representatividade adequada na Ação Coletiva Brasileira (Lei da Ação Civil Pública e Código de Defesa do Consumidor). Dissertação de Mestrado, São Paulo, Faculdade de Direito da USP, 2007, p. 106-109.

VIOLIN, Jordão. Ação coletiva passiva: fundamentos e perfis. Salvador: JusPodivm, 2008.

WALD, Arnoldo, Curso de Direito Civil Brasileiro - Introdução e Parte Geral, 6. ${ }^{\mathrm{a}}$ ed., v. 1, São Paulo: Ed. RT, 1989, p. 133.

WAMBIER, Luiz Rodrigues. O Mandado de Segurança na Disciplina da Lei 12.016, de 07.08.2009, Revista de Processo, v. 177, São Paulo: Ed. RT, 2009, p. 185.

WAMBIER, Luiz Rodrigues; e VASCONCELOS, Rita de Cássia Corrêa de. $O$ mandado de segurança na disciplina da Lei 12.016, de 07.08.2009, Revista de Processo, v. 177, São Paulo: Ed. RT, 2009, p. 185 e ss.

WATANABE, Kazuo. Demandas coletivas e os problemas emergentes da práxis forense. Revista de Processo. vol. 67. São Paulo: Ed. RT, jul.-set. 1992. p. 15.

Código de Defesa do Consumidor comentado pelos autores do anteprojeto. Rio de Janeiro: Forense Universitária, 2004, p.824 e ss.

Disposições gerais. In: GRINOVER, Ada Pellegrini et al (orgs.). Código brasileiro de Defesa do Consumidor: comentado pelos autores do Anteprojeto, $8^{\mathrm{a}}$ ed. Rio de Janeiro: Forense Universitária, 2004. 
. Código de Defesa do Consumidor comentado pelos autores do anteprojeto. Rio de Janeiro: Forense Universitária, 2004.

. Da Cognição no Processo Civil, São Paulo: Ed. RT, 1987, p.

58.

Relação entre demanda coletiva e demandas individuais. In GRINOVER, Ada Pellegrini; MENDES, Aluísio Gonçalves de Castro e WATANABE, Kazuo (coord.). Direito Processual Coletivo e o Anteprojeto de Código Brasileiro de Processos coletivos. São Paulo: Ed. RT, 2007, p. 160.

Tutela jurisdicional dos interesses difusos: a legitimação para agir, In: A tutela dos interesses difusos. São Paulo: Max Limonad, 1984. p. 90.

YOSHIDA, Consuelo Yatsuda Moromizato. Tutela dos interesses difusos e coletivos. São Paulo: Juarez de Oliveira, 2006.

YOSHIKAWA, Eduardo Henrique O., Da ilegitimidade ativa de órgãos do Poder legislativo para propor ação civil pública em defesa de interesses difusos, coletivos e Individuais homogêneos, Rev. Dialética no 31, pp. 45-49; 62-63.

ZANETI JR., Hermes. Mandado de Segurança Coletivo - Aspectos Controversos, Porto Alegre: Ed. Sergio Antonio Fabris, 2001, p. 95, 124-138.

ZANETI JR., Hermes. A efetividade do mandado de segurança coletivo no Código Brasileiro de Processos Coletivos. In: Grinover, Ada Pellegrini; Mendes, Aluisio Gonçalves de Castro; Watanabe, Kazuo. Direito processual coletivo e o Anteprojeto de Código Brasileiro de Processos Coletivos. São Paulo: Ed. RT, 2007. p. 401. Direitos coletivos lato sensu: a definição conceitual dos direitos difusos, dos direitos coletivos stricto sensu e dos direitos individuais homogêneos. Disponível em: http://www.abdpc.org.br/abdpclartigos/Hermes\%20Zaneti\%20Jr(2)\%20\%20formatado.pdf

ZAVASCKI, Teori Albino. Processo coletivo: tutela de direitos coletivos e tutela coletiva de direitos. São Paulo: Ed. RT, 2006. 
Defesa de direitos coletivos e defesa coletiva de direitos, Revista Jurídica, no 212, Porto Alegre, 1995, pp. 23 e ss.

ZUFELATO, Camilo. Da Legitimidade Ativa ope legis da Defensoria Pública para o Mandado de Segurança Coletivo - Uma Análise a Partir do Microssistema de Direito Processual Coletivo Brasileiro e o Diálogo das Fontes, Revista de Processo, v. 203, são Paulo: Ed. RT, 2012, p. 321 e ss. 


\section{Resumo}

O presente trabalho tem por escopo o estudo da legitimação ativa no mandado de segurança coletivo no Brasil à luz da legislação vigente sobre o tema, da doutrina e jurisprudência pátrias.

Buscou-se, de início trazer uma leitura contemporânea das condições da ação e especificamente da possibilidade jurídica do pedido e interesse processual no que interessam à legitimidade. Traçou-se o conceito de legitimidade e as correntes doutrinárias que definem o instituto, especialmente para fins da tutela coletiva.

Após, procurou-se definir a representatividade adequada e a pertinência temática, principalmente no que interessa à definição da legitimidade ativa em demandas coletivas e no mandado de segurança coletivo.

Quanto ao mandado de segurança, incialmente foram aduzidos os pontos relevantes ao instituto em sua espécie individual, expondo sobre a evolução histórica deste e sua natureza.

Paralelamente a isso, asseverou-se sobre o histórico doutrinário e normativo da tutela de direitos coletivos, bem como os pontos relevantes atinentes à legitimação no mandado de segurança coletivo especificamente.

Por fim, foram relacionados os legitimados ope legis para o mandado de segurança coletivo, trazendo-se a sugestão de outros legitimados a partir de uma interpretação sistêmica da normatização de tutela dos direitos coletivos. Concluiu-se o trabalho com a menção a duas situações concretas específicas que interessam à atuação dos legitimados e tratam da limitação da atuação destes. 


\section{Riassunto}

Il scopo centrale di questo studio è l'analisi dell' istituto della legittimazione attiva in atto collettivo di mandamus in Brasile, alla luce della normativa vigente in materia, dottrina e giurisprudenza patrie.

Abbiamo cercato inizialmente di portare una lettura contemporanea delle condizioni dell'azione e, in particolare, la possibilità giuridica della domanda, interesse procedurale e legittimità. Tracciato il concetto della legittimità e il tendenze dottrinali che definiscono l'istituto, in particolare ai fini della protezione collettiva .

Dopo, abbiamo cercato di definire un'adeguata rappresentazione e la pertinenza tematica, in particolare per quanto riguarda la definizione di legittimazione attiva su le richieste collettivi e atto collettivo di mandamus.

Quanto al atto collettivo di mandamus, inizialmente sono stati messi i punti su il instituto nelle loro singole specie, l'evoluzione storica di questo e la sua natura .

Parallelamente a ciò, se affermato sulla storia dottrinale e normativa della tutela di diritti collettivi, come pure delle punti pertinenti relative alla legittimità in atto collettivo di mandamus specificamente.

Infine, abiamo tratato su il legittimati definiti nella legge per l'atto collettivo di mandamus, portando il suggerimento di altri legittimati da una interpretazione sistematica delle norme di tutela dei diritti collettivi. Si è concluso il lavoro con riferimento a due situazioni concrete di interesse specifico per la prestazione degli legittimati e su la limitazione della prestazioni di questi. 